\title{
ESTABELECIMENTO DE PARÂMETROS AGRONÔMICOS PARA O MANEJO E EFICIÊNCIA DE UTILIZAÇÃO DE Panicum maximum Jacq. cv TANZÂNIA 1 SOB PASTEJO ROTACIONADO.
}

\section{PAULO TOSI}

Engenheiro Agrônomo

Orientador: Prof. Dr. MOACYR CORSI

Dissertação apresentada à Escola Superior de Agricultura "Luiz de Queiroz", Universidade de São Paulo, para obtenção do título em Mestre em Agronomia, Área de Concentração: Ciência Animal e Pastagens.

PIRACICABA

Estado de São Paulo - Brasil

Março - 1999 
Dados Internacionais de Catalogação na Publicação (CIP)

DIVISÃo DE BIBLIOTECA E DOCUMENTAÇĀo - Campus "Luiz de Queiroz"/USP

\section{Tosi, Paulo}

Estabelecimento de parâmetros agronômicos para o manejo e eficiência de utilização de Panicum maximum ]acq. cv Tanzânia 1 sob pastejo rotacionado / Paulo Tosi. - - Piracicaba, 1999.

103 p.

Dissertação (mestrado) - Escola Superior de Agricultura Luiz de Queiroz, 1999. Bibliografia.

1. Capim colonião 2. Caracteristica agronomica 3. Desempenho animal 4. Graminea forrageira 5. Manejo integrado 6. Pastejo rotacionado 7. Produtividade agricola 1. Título

CDD 633.2 
Aos meus pais,

Hugo Tosi e Rosa Helena

Por sua dedicação e carinho

\section{Dedico.}




\section{AGRADECIMENTOS}

- Ao Prof. Dr. Moacyr Corsi o meu maior agradecimento, pela contribuição para a minha formação, pelas oportunidades dadas e pelo exemplo de profissionalismo.

- Ao Centro de Pesquisa de Pecuária do Sudeste-Embrapa São Carlos, na pessoa do Chefe Geral Dr. Aliomar G. da Silva pela oportunidade de execução do experimento.

- Aos Pesquisadores da Embrapa Dr. Luciano de Almeida Corrêa e Dr. Sérgio Novita Esteves, pela orientação e amizade.

- Aos meus amigos Eng ${ }^{\circ}$ Agron $^{\circ}$ Daniel Silva Pagotto e Eng $^{\circ}$ Agron $^{\circ}$ Ricardo de Paula M. Cunha, pela amizade e ajuda na condução do experimento.

- Aos Professores Dr. Sila Carneiro da Silva, Dr. Carlos Guilherme Silveira Pedreira, Dr. Luis Gustavo Nussio e Dr. Wilson R. S. Mattos, pelos esclarecimentos e orientações.

- Ao Prof. Dr. Luiz Roberto de Andrade Rodrigues pela ajuda e orientação no trabalho de pesquisa.

- Aos Professores do Curso de Pós-Graduação em Ciência Animal e Pastagens, pelo conhecimento transmitido.

- Ao meu pai Dr. Hugo Tosi, pelo incentivo para a realização do Curso de PósGraduação.

- Aos meus amigos do Curso de Pós- Graduação em Ciência Animal e Pastagens, pelos bons momentos.

- A Fundação de Auxilio a Pesquisa do Estado de São Paulo- FAPESP, pela concessão da bolsa de auxilio a pesquisa.

- A CAPES, pela concessão de bolsa de estudos.

- Ao Departamento de Zootecnia da ESALQ.

- A Escola Superior de Agricultura "Luiz de Queiroz" - ESALQ, pela minha formação profissional.

- Aos meus amigos da Republica Senzala, pelos bons momentos em todos esses anos morando juntos e pelo apoio. 


\section{SUMÁRIO}

Página

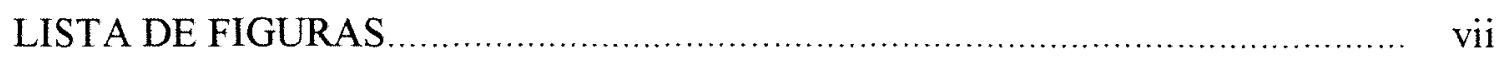

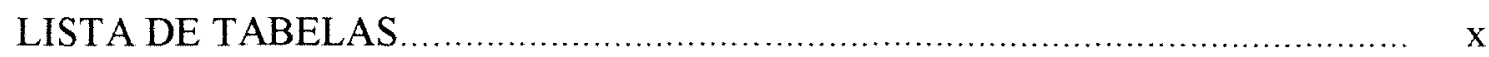

LISTA DE ABREVIATURAS E SÍMBOLOS ............................................. xii

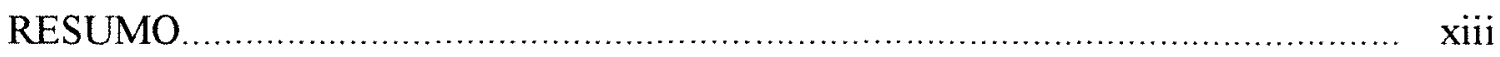

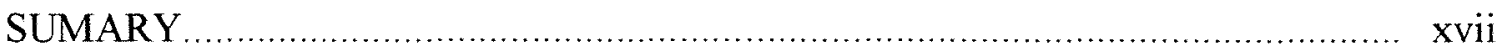

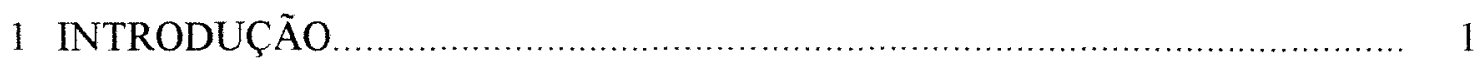

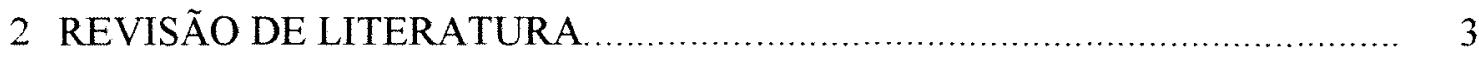

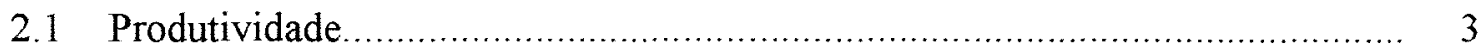

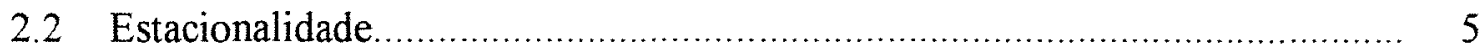

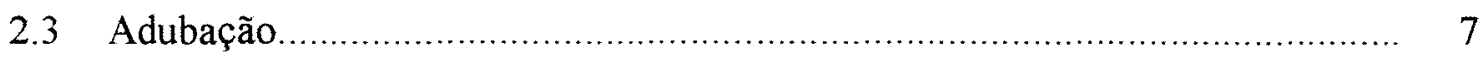

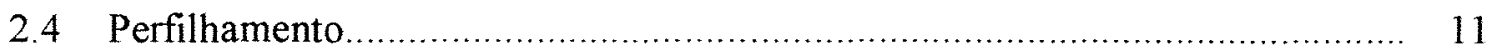

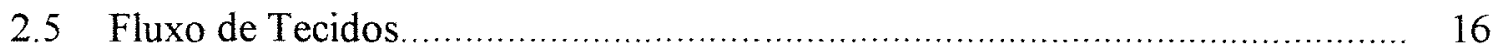

2.6 Freqüência de corte, período de ocupação e área foliar remanescente........... 18

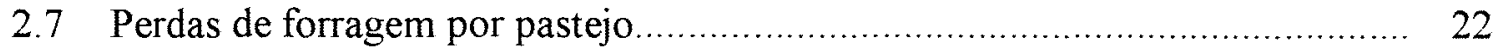

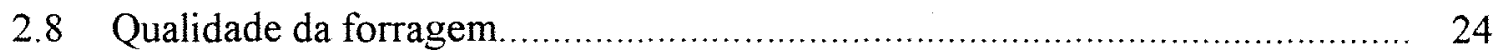

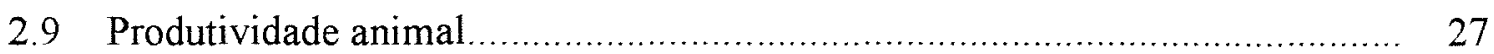

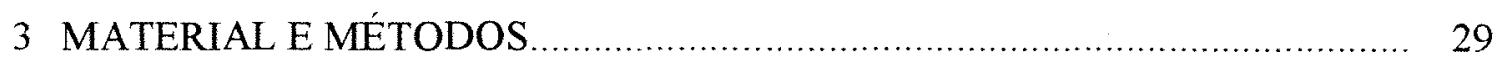

3.1 Variáveis determinadas.............................................................. 31

3.1.1 Avaliação da produção de matéria seca e taxa de acúmulo....................... 31

3.1.2 Dinâmica populacional de perfilhos ............................................... 31 


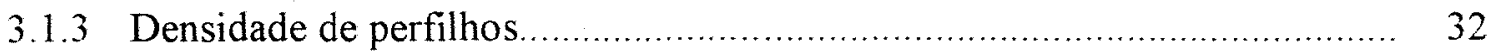

3.1 .4 Fluxo e renovação de tecidos....................................................... 32

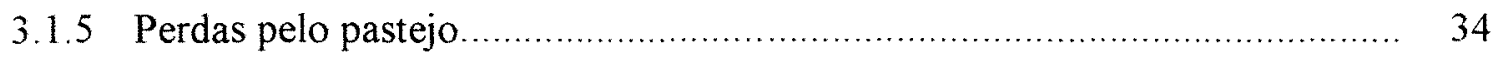

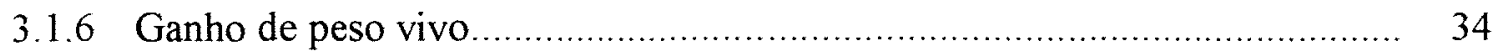

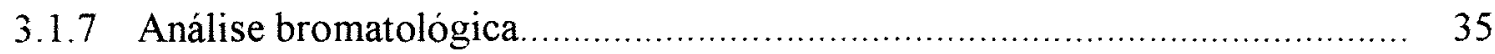

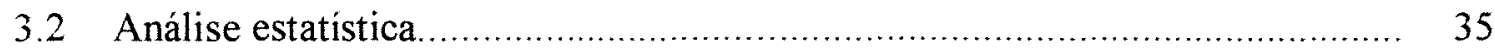

4 RESULTADOS E DISCUSSÃO

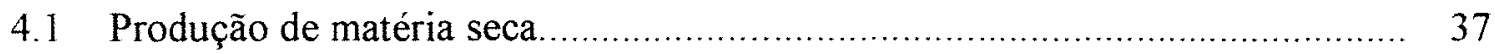

4.2 Valor Nutritivo da forragem.................................................. 41

4.3 Perdas de forragem pelo pastejo ........................................................ 47

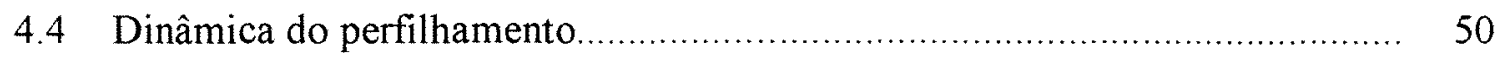

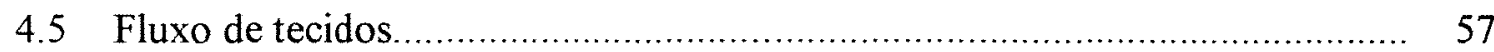

4.6 Ganho de peso vivo e produtividade animal .......................................... 72

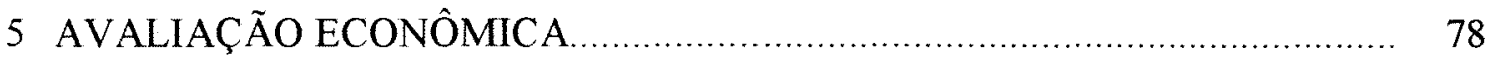

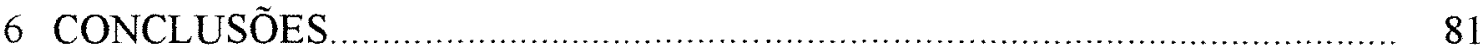

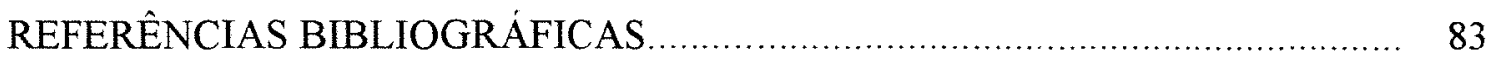

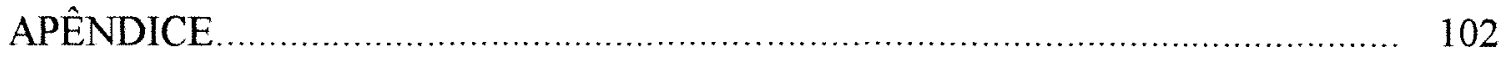




\section{LISTA DE FIGURAS}

Página

1 Precipitação $(\mathrm{mm})$ e temperatura média mensal $\left({ }^{\circ} \mathrm{C}\right)$ de outubro de 1996 a dezembro de 1997.

2 Produção de matéria seca $\left(\mathrm{kg} \mathrm{MS} \mathrm{ha}{ }^{-1}\right)$ do capim Tanzânia 1 durante o período experimental de 24/12/96 à 23/12/97. 38

3 Taxa de acúmulo da matéria seca ( $\mathrm{kg} \mathrm{MS} \mathrm{ha} \mathrm{dia}^{-1}$ ) do capim Tanzânia 1 durante o período experimental de 24/12/96 à 23/12/97. 40

4 Variação da porcentagem de matéria seca do capim Tanzânia 1 durante o período experimental

5 Variação nos teores de proteína bruta (\%) do capim Tanzânia 1 durante o período experimental.

6 Variação nos teores de fibra em detergente neutro (\%) do capim Tanzânia 1 durante o período experimental. 45

7 Variação na digestibilidade verdadeira "in vitro" da matéria seca (\%) do capim Tanzânia 1 durante o período experimental 46

8 Perdas de forragem pelo pastejo ( $\left.\mathrm{kg} \mathrm{MS} \mathrm{ha}{ }^{-1}\right)$ do capim Tanzânia 1 durante o período experimental 49

9 Densidade populacional de perfilhos (perfilhos $\mathrm{m}^{-2}$ ) do capim Tanzânia 1 durante o período experimental. 
10 Taxa de aparecimento de perfilhos (\%) no capim Tanzânia 1 durante o período experimental 54

$1 \quad 1$ Taxas de sobrevivência e mortalidade (\%) de perfilhos do capim Tanzânia 1 durante o periodo experimental.

12 Dinâmica do perfilhamento (Perfilhos área ${ }^{-1}$ ) do capim Tanzânia 1 durante o período experimental. 56

13 Crescimento da hastes do capim Tanzânia 1 durante o período experimental 60

14 Crescimento das folhas do capim Tanzânia $1\left(\mathrm{~cm} \mathrm{dia}^{-1} \mathrm{e} \mathrm{mg} \mathrm{dia}{ }^{-1}\right)$ durante o período experimental

15 Senescência de folhas ( $\left.\mathrm{cm} \mathrm{dia}^{-1} \mathrm{e} \mathrm{mg} \mathrm{dia}{ }^{-1}\right)$ do capim Tanzânia 1 durante o período experimental 65

16 Comparação entre taxas de acúmulo de matéria seca $\left(\mathrm{kg} \mathrm{ha}^{-1}\right)$ no capim Tanzânia 1 determinadas através de cortes e fluxo de tecidos. 66

17 Número de folhas vivas por perfilho e taxas de aparecimento de folhas (dias folha ${ }^{-1}$ ) no capim Tanzânia 1 durante o período experimental. 71

18 Variação da lotação $\left(\mathrm{UA} \mathrm{ha}^{-1)}\right.$ nos periodos das "águas" (27/11/96 à 28/04/97) e da "seca" (29/04/97 à 30/11/97) no capim Tanzânia 1 75

19 Produtividade mensal ( $\mathrm{kg} \mathrm{PV} \mathrm{ha}^{-1}$ ) no período de dez/96 à nov/97. 
20 Composição relativa dos custos de produção de carne em pastagem de capim Tanzânia 1 no período de dezembro de 1996 a dezembro de 1997 


\section{LISTA DE TABELAS}

Página

1 Médias de produção de matéria seca por pastejo ( $\mathrm{kg} \mathrm{MS} \mathrm{ha}^{-1}$ ), taxa de acúmulo de matéria seca $\left(\mathrm{kg} \mathrm{MS} \mathrm{ha}{ }^{-1} \mathrm{dia}^{-1}\right)$ e seus correspondentes e desvios padrão e coeficientes de variação

2 Médias de \% de matéria seca, digestibilidade verdadeira "in vitro" da matéria seca (\%), fibra em detergente neutro (\%), proteína bruta (\%) e seus correspondentes desvios padrão e coeficientes de variação.

3 Perdas de forragem pelo pastejo e seus desvios padrão e coeficientes de variação

4 Médias de densidade populacional de perfilhos $\mathrm{m}^{-2}$ e seus desvios padrão e coeficientes de variação. 50

5 Taxas de aparecimento, mortalidade e sobrevivência de perfilhos em porcentagem e seus correspondentes desvios padrão e coeficientes de variação.

6 Médias de crescimento de haste (cm haste ${ }^{-1} \mathrm{dia}^{-1}$ e $\mathrm{mg}_{\text {haste }} \mathrm{c}^{-1}$ dia $^{-1}$ ) e seus desvios padrão e coeficientes de variação 58

7 Taxas de crescimento de folhas ( $\mathrm{cm}$ folh $^{-1}$ dia e $\mathrm{mg}$ folha ${ }^{-1}$ $\operatorname{dia}^{-1}$ ) e seus desvios padrão e coeficientes de variação

8 Taxas de senescência de folhas ( $\mathrm{cm} \mathrm{dia}^{-1}$ e $\mathrm{mg} \mathrm{dia}^{-1}$ ) e seus desvios padrão e coeficientes de variação 
9 Médias de número de folhas vivas por perfilho e seus desvios padrão e coeficientes de variação

10 Taxas de aparecimento de folhas (dias folhas ${ }^{-1}$ ) e seus desvios padrão e coeficientes de variação. 70

11 Médias de ganho de peso (kg animal ${ }^{-1} \mathrm{dia}^{-1}$ ) nos periodos das "águas" e da "seca" e seus desvios padrão, coeficientes de variação e peso médio inicial e final dos animais

12 Análise econômica do período das "águas" no sistema de pastejo rotacionado com o capim Tanzânia 1

13 Análise econômica do período da "seca" no sistema de pastejo rotacionado com o capim Tanzânia 1 79

14 Lucratividade do sistema de pastejo rotacionado com capim Tanzânia 1 no período de dezembro de 1996 à novembro 1997 


\section{LISTA DE ABREVIATURAS E SÍMBOLOS}

AOAC
DVIVMS
DIVMS
FDN
ha
KCl
MS
N
PB
t
UA
@

Association of Official Analytical Chemists

Digestibilidade verdadeira in vitro da matéria seca

Digestibilidade in vitro da matéria seca

Fibra insolúvel em detergente neutro

hectare

Cloreto de potássio

Matéria seca

Nitrogênio

Proteina bruta

Tonelada

Unidade animal

Arroba 


\begin{abstract}
ESTABELECIMENTO DE PARÂMETROS AGRONÔMICOS PARA O MANEJO E EFICIÊNCIA DE UTILIZAÇÃO DE Panicum maximum Jacq. cv TANZÂNIA 1 SOB PASTEJO ROTACIONADO.
\end{abstract}

Autor: PAULO TOSI

Orientador: Prof. Dr. MOACYR CORSI

\title{
RESUMO
}

O presente trabalho teve por objetivo estabelecer alguns parâmetros para nortear o método de pastejo rotacionado do cultivar Tanzânia 1 (Panicum maximum), utilizando-se um ciclo de pastejo de 36 dias (33 dias de descanso e 3 dias de ocupação) durante o periodo das "águas"(27/11/96 à 28/04/97) e 72 dias (66 dias de descanso e 6 dias de ocupação) durante o período da "seca" $(29 / 04 / 97$ à $30 / 11 / 97)$.

O experimento foi conduzido no Centro de Pesquisa de Pecuária do Sudeste - Embrapa, município de São Carlos - SP (latitude $22^{\circ} 01^{\prime} \mathrm{S}$, longitude $47^{\circ} 53^{\prime} \mathrm{W}$ e altitude de $854 \mathrm{~m}$ ), em uma área de 8 ha em solo classificado como Latossolo Vermelho Amarelo. A área foi dividida em 13 piquetes de $6200 \mathrm{~m}^{2}$, reservando-se uma área central de $1200 \mathrm{~m}^{2}$ para acesso ao saleiro e ao bebedouro.

A adubação de cada piquete foi feita em cobertura logo após o pastejo, que era realizado até que a planta forrageira apresentasse uma altura de resíduo de $35-40 \mathrm{~cm}$. A lotação animal era regulada pela adição ou retirada de animais da área experimental. Foram utilizados dois lotes de animais machos puros da raça Canchim 
com peso médio inicial de 338 e $258 \mathrm{~kg}$ no período do "águas" e "seca", respectivamente.

A adubação foi realizada no período das "águas" (dezembro à abril), utilizando-se a fórmula 20-05-20 na quantidade de $400 \mathrm{~kg}$ $\mathrm{ha}^{-1}$ ou seja utilizou-se $320 \mathrm{~kg} \mathrm{~N} \mathrm{ha}^{-1} \mathrm{ano}^{-1}$.

Avaliaram-se as seguintes variáveis, que foram submetidas cálculos de estatística descritiva: produção de matéria seca, taxa de acúmulo de matéria seca, porcentagem de matéria seca, digestibilidade verdadeira "in vitro" da matéria seca, fibra em detergente neutro, proteína bruta, ganho de peso vivo, densidade populacional de perfilhos, aparecimento, mortalidade e sobrevivência de perfilhos, perdas de pastejo, taxa de alongamento foliar, taxa de alongamento de hastes, taxa de senescência, número de folhas vivas por perfilho, taxa de aparecimento de folhas.

A produção de matéria seca obtida durante as "águas" e "seca" foi de 23,6 e 5,9 $\mathrm{t}$ MS ha ${ }^{-1}$, o que permitiu uma lotação média de 6,6 e 2,7 $\mathrm{UA} \mathrm{ha}^{-1}$, respectivamente. A taxa de acúmulo de matéria seca atingiu o máximo de $183 \mathrm{~kg} \mathrm{MS} \mathrm{ha}^{-1} \mathrm{dia}^{-1}$ no mês de janeiro, apresentando uma redução nos períodos subsequentes com um mínimo de $23 \mathrm{~kg}$ MS $\mathrm{ha}^{-1} \mathrm{dia}^{-1}$ no período de agosto e setembro, demonstrando acentuada estacionalidade de produção.

A forragem apresentou uma perda de qualidade no período da "seca". A porcentagem de matéria seca apresentou uma variação entre 22 e $24 \%$, apresentando os valores maiores no período de junho a setembro.

As perdas pelo pastejo apresentaram uma evidente estacionalidade, apresentando valores superiores nos pastejos 
realizados nas "águas", atingindo a perda máxima de $1905 \mathrm{~kg}$ MS $\mathrm{ha}^{-1}$ no pastejo realizado em fevereiro.

$\mathrm{Na}$ avaliação de densidade populacional de perfilhos, obtevese valores relativamente menores nos pastejos iniciais (pastejo 1 ao 3), oscilando entre 415 a 429 perfilhos $\mathrm{m}^{-2}$ no periodo experimental. Houve uma variabilidade nas categorias de perfilhos que compõem a população da pastagem, devido a queda nas taxas de aparecimento no período da "seca". Concluiu-se que seria importante determinar qual a categoria de perfilhos responsável pela maior parte da produção e basear o manejo no comportamento desta.

A taxa média de alongamento de folhas foi de 4,11 e $1,28 \mathrm{~cm}$ folha $^{-1} \mathrm{dia}^{-1}$, para as "águas" e "seca", respectivamente. A taxa de senescência média no período do "verão" foi de $0,4 \mathrm{~cm} \mathrm{dia}{ }^{-1}$ e praticamente nula no "inverno". A taxa de acúmulo de matéria seca a partir da avaliação de fluxo de tecidos apresentou resultados satisfatórios, quando comparados aos dados de corte da forragem, já que as curvas apresentaram a mesma tendência. O número de folhas vivas por perfilho se manteve constante durante o ano, apresentando uma média de 4,0 com exceção do período de $03 / 07 / 97$ à 14/09/97 que apresentou 2,7 folhas vivas perfilho-1 ${ }^{-1}$ Há uma regularidade no aparecimento de folhas novas, com médias oscilando entre 10,2 e 12 dias folha $^{-1}$ durante o ano. Entretanto o período entre $27 / 04 / 97$ à $14 / 09 / 97$ apresentou as maiores médias, atingindo o valor máximo de 55 dias folha ${ }^{-1}$.

O ganho de peso vivo médio obtido com os bovinos foi de 0,82 e $0,53 \mathrm{~kg}$ animal $^{-1} \mathrm{dia}^{-1}$ e a produtividade foi de 910 e $460 \mathrm{~kg}$ 
PV ha ${ }^{-1}$ nos períodos das "águas" e "seca", respectivamente, sendo considerados excelentes.

O sistema de pastejo intensivo do capim Tanzânia 1 apresentou viabilidade econômica, com um lucro estimado de US\$530,04 $\mathrm{ha}^{-1}$ ano $^{-1}$. 


\section{ESTABLISHMENT OF AGRONOMIC PARAMETERS FOR EFFICIENT \\ UTILIZATION AND MANEGEMENT OF Panicum maximum Jacq. cv TANZANIA 1 UNDER ROTACIONAL GRAZING}

Author: PAULO TOSI Adviser: Prof. Dr. MOACYR CORSI

SUMMARY

This work was carried out to establish grazing manegement parameters of Tanzania (Panicum maximum) grass under rotational grazing. The grazing cicle was 36 days (33 days rest and 3 days grazing) during the $1996 / 1997$ wet season (27 Nov. to 28 April) and 72 days (66 days rest and 6 days grazing) during the 1997 dry season (29 April to 30 Nov.).

The experiment was conducted at the Southeast Livestock Research Center -EMBRAPA, in São Carlos - SP $\left(22^{\circ} 01^{\prime} \mathrm{S}\right.$, $47^{\circ} 53^{\prime} \mathrm{W}$, of $854 \mathrm{~m}$ above sea level). The experimental area was on 8 ha of a yellow red latosol divided in 13 paddocks of $6200 \mathrm{~m}^{2}$. A central area of $1200 \mathrm{~m}^{2}$ was common to all paddocks for water and mineral supplementation to the animals.

Each paddock was top dressed after each grazing with a postgrazing height of $35-40 \mathrm{~cm}$. Stocking rate was adjusted using the "put-and-take" method. Two lots of pure Canchim steers with an initial average live weight of 338 and $258 \mathrm{~kg}$ (for the summer and winter groups, respectively) were used. 
xviii

The fertilization consisted of $320 \mathrm{~kg} \mathrm{~N} \mathrm{ha}^{-1}$ year $^{-1}$ applied during the wet season (December - April), using a $20-05-20$ formula.

The variables were analyzed by descriptive statistics. The following responses were evaluated: dry matter production, dry matter accumulation rate, dry matter percentage, in vitro dry matter digestibility, neutral detergent fiber content, crude protein content, animal live weight gain, tiller population density, tiller death, tiller appearance, losses of herbage due to grazing, leaf elongation rates, stem elongation rates, senescence rate, number of live leaves per tiller and leaf appearance rates.

Total herbage accumulated during "wet" and "dry" seasons, was 23,6 and $5.9 \mathrm{t}$ of dry matter $\mathrm{ha}^{-1}$, which allowed average carrying capacities of 6.6 and $2.7 \mathrm{AU} \mathrm{ha}^{-1}$, respectively. Herbage accumulation rates reached a maximum of $183 \mathrm{~kg}$ of $\mathrm{DM} \mathrm{ha}^{-1} \mathrm{day}^{-1}$ in January, and a minimum of $23 \mathrm{~kg} \mathrm{DM} \mathrm{ha}{ }^{-1} \mathrm{day}^{-1}$ in August and September.

The loss of herbage due to grazing showed a seasonal pattern, with higher values during the wet period, and a maximum loss of $1905 \mathrm{~kg} \mathrm{DM} \mathrm{ha}^{-1}$ in February.

Tiller population density was lowest at the beginning of the experimental period (grazing 1 to 3 ), reaching values between 415 and 429 tillers $\mathrm{m}^{-2}$. There was variability among tiller categories when tiller population and weight were considered. It was concluded that there is a need to determine which tiller category is the most important for dry matter production in order to determine the management strategy based on this tiller category. 
The average leaf elongation rate was 4.11 and $1.28 \mathrm{~cm} \mathrm{leaf}^{-1}$ day $^{-1}$ during the wet and the dry seasons, respectively. The senescence rate during the wet season was $0.4 \mathrm{~cm} \mathrm{day}^{-1}$ and there was no senescence during the dry season. Herbage accumulation rate calculated from the tissue flow data presented satisfactory results when compared to forage harvested, since the herbage accumulation curves showed the same trend. The number of live leaves per tiller remained constant throughout the year showing an average of 4.0 leaves per tiller, except during the period from July 3 to September $17,2.7$ leaves per tiller. Leaf appearance rates, ranged from 10.2 and 12 days per leaf. However during the period $27 / 04 / 97$ to $14 / 09 / 97$ high values of leaf appearance rate were observed, reaching 55 days per leaf.

The average animal live weight gain was 0.82 and $0.53 \mathrm{~kg}$ day $^{-1}$ during the wet and dry seasons, respectively. The live weight gain per hectare was 910 and $460 \mathrm{~kg}$ during wet and dry seasons, respectively.

The intensive Canchin/Tanzania 1 grass grazing system showed economic viability with a profit estimated in US\$530.04 $\mathrm{ha}^{-1}$ year ${ }^{-1}$. 


\section{INTRODUÇÃO}

O P. maximum sempre despertou muito interesse entre pesquisadores e pecuaristas, provavelmente devido à alta produtividade e qualidade da forragem. Todavia, se não são observadas algumas técnicas de manejo, essas pastagens se degradam rapidamente e o coloniăo dá lugar para espécies de hábito prostrado, geralmente menos exigentes e mais resistentes ao manejo inadequado, porém, de menor potencial de produção.

As gramíneas do gênero Panicum têm sido umas das principais forrageiras cultivadas no Brasil (Furlan, 1969). Segundo Carriel et al. (1979) há três décadas ocupava $32 \%$ da área das pastagens no Estado de São Paulo. Atualmente estimou-se uma ocupação de apenas $5 \%$ da mesma área (Săo Paulo, 1997).

Recentemente aumentou $o$ interesse pela utilização do $P$. maximum em funçâo da liberação de novos cultivares por diversos órgãos de pesquisa do Brasil, tais como o Tanzânia 1, Tobiatã, IZ-1, Mombaça, Vencedor e Centauro que apresentam alto potencial produtivo.

Corsi (1988) apontou o ressurgimento do interesse pelo capim colonião, através de novos cultivares, lançados pelos institutos de 
pesquisas, como um fato histórico, desde que acompanhado de novos critérios de exploração e manejo dessa importante espécie forrageira.

Entretanto, é de fundamentai importância que os principios de manejo sejam conhecidos e praticados para que as espécies e cultivares de Panicum possam se manter produtivos e persistentes nas pastagens (Rodrigues \& Reis, 1995).

Para se explorar o potencial da espécie forrageira, visando elevados índices de produtividade animal, é necessário que se adote técnicas de manejo adequadas á cada espécie Para isso, torna-se necessário o conhecimento das alterações morfo-fisiológicas que interferem na produtividade agronômica da planta forrageira durante o ciclo de pastejo. 


\section{REVISÃO DE LITERATURA}

\subsection{Produtividade}

As variedades de capim Panicum têm elevado potencial de produção, podendo ser destacadas pela alta produtividade de matéria seca durante o ano, atingindo níveis máximos de produção de $53 \mathrm{t}$ MS $\mathrm{ha}^{-1}$, sendo que a média de produtividade poderia ser estabelecida entre 20-30 $\mathrm{t} \mathrm{MS} \mathrm{ha}^{-1}$ ano $^{-1}$ (Usberti Filho, 1987).

Iljin (1958) realizou experimentos de adubação do capim Colonião (Panicum maximum, Jacq) efetuando cortes aos 37 dias (pré-floração), aos 68 dias (floração), e aos 128 dias (frutificação) e obteve produções até cinco vezes maiores que a testemunha sem adubo. A maior produção foi obtida com 128 dias de vegetaçào $(93 \mathrm{t}$ MS ha ${ }^{-1} a^{-1}$ ), mediante a aplicação de nitrogênio e fósforo, além de micro-elementos $(\mathrm{Mg}, \mathrm{Zn}, \mathrm{Cu}, \mathrm{B})$.

Vicente-Chandler et al. (1962) comparando várias forrageiras tropicais em Porto Rico, obtiveram a melhor produçăo com capim Colonião (31 t MS ha $\left.\mathrm{ano}^{-1}\right)$ utilizando um intervalo entre cortes de 60 dias e aplicação de adubos nitrogenados na taxa de $800 \mathrm{~kg}$ de $\mathrm{N}$ $\mathrm{ha}^{-1} \mathrm{ano}^{-1}$. 
Savidan et al. (1990) e Jank et al. (1994), comparando 25 acessos selecionados de Panicum maximum conseguiram produções médias e máximas, respectivamente, entre as melhores variedades de Panicum, de 36 ton. e 44 ton. MS ha ${ }^{-1}$ nno $^{-1}$ nas áreas não adubadas, e 44 ton. e 53 ton. MS ha ${ }^{-1}$ ano $^{-1}$ nas áreas que receberam $1,5 \mathrm{t} \mathrm{ha}^{-1}$ de calcário dolomítico, $800 \mathrm{~kg} \mathrm{ha}^{-1}$ de super fosfato simples, $130 \mathrm{~kg}$ $\mathrm{ha}^{-1}$ de $\mathrm{KCl}, 40 \mathrm{~kg} \mathrm{ha}^{-1}$ de FTE-BR 16 e $100 \mathrm{~kg} \mathrm{ha}^{-1}$ de uréia após o corte de uniformização. Os mesmos autores ainda relataram que cerca de $58 \%$ dos acessos estudados foram melhores do que o capim Coloniăo quando as áreas não foram adubadas. Entretanto, nas áreas adubadas, $47 \%$ dos acessos estudados tiveram uma produção superior ao Colonião.

Usbertti Filho (1987) através de ensaios de competiçăo entre cultivares de Panicum realizados em Araçatuba-SP e Mococa-SP nos anos agrícolas de $1982 / 83$ e 1983/84, observou que o cultivar Centauro produziu $30,5 \mathrm{t} \mathrm{MS} \mathrm{ha}^{-1}$ ano $^{-1}$ representando um acréscimo de $113 \%$ acima do cultivar coloninho usado como controle. O manejo do Centauro neste trabalho foi efetuado através de cinco cortes realizados a intervalos de 45 dias e na altura de $10 \mathrm{~cm}$ do solo. A adubação foi de $200 \mathrm{~kg} \mathrm{~N} \mathrm{ha}^{-1} \mathrm{ano}^{-1}$ subdivididos após cada corte.

Savidan et al. (1990) compararam 156 acessos de Panicum e constataram que o Mombaça produziu $28 \%$ mais que o Tanzânia 1 e 2,3 vezes mais do que o Colonião, e que o Tanzânia 1 produziu cerca de $80 \%$ mais do que o Colonião. As produções de matéria seca total foram de 14,$3 ; 25,6$; e $32,9 \mathrm{t} \mathrm{MS} \mathrm{ha}^{-1} \mathrm{ano}^{-1}$ para os capins Colonião, Tanzânia 1 e Mombaça, respectivamente. 
Jank et al. (1994) comparando as diferenças entre as cultivares Tanzània 1, Mombaça, Tobiatã e Coloniào, observaram a superioridade dos très cultivares em relação ao Colonião para todas as características avaliadas, exceto a produção de sementes do cultivar Mombaça. As produções de matéria seca para o Tanzânia 1, Mombaça e Tobiatã foram, respectivamente, de $86 \%, 136 \%$ e $96 \%$ maiores do que aquela do Coloniào.

Savidan et al.(1990) e Jank et al.(1994) relataram que o capim Colonião, quando adubado, produz 1,9 vezes mais do que quando não adubado.

\subsection{Estacionalidade}

Recentemente, grande número de cultivares da espécie P.maximum foram lançados comercialmente por diversos órgãos de pesquisa do Brasil, sendo que alguns deles compõem, no presente, expressiva área de produção de pastagens. Apesar de conseguir-se selecionar materiais genéticos cujas produções de matéria seca são muito maiores do que as obtidas pela variedade colonião, ainda năo se conseguiu resolver o problema da estacionalidade de produção dessas plantas forrageiras (Jank et al.,1994). Esses autores determinaram que os 25 acessos mais produtivos não apresentaram estacionalidade de produção favorável e registraram para o inverno produções que variaram entre 5 e $13 \%$ da produção anual. Concluíram que, devido à correlação negativa entre estacionalidade de produção e a produção de matéria seca foliar, pode ser difícil a 
seleção de plantas com alta produtividade de matéria seca com pequena estacionalidade.

O sistema de manejo das pastagens no Brasil é, em grande parte, caracterizado pelo "pastejo" contínuo, com lotação animal determinada pela produtividade da forragem no período de escassez de produção. O uso dessas pastagens, sem alimentação suplementar durante o periodo crítico de produção das plantas forrageira, é feito com pressão de pastejo muito elevada no início do período de crescimento (verão), quando ocorre a rebrota das pastagens. Após esse período, a pressão é muito leve, permitindo ao animal elevada seletividade, o que provoca um pastejo desuniforme, degradação e perdas durante o pastejo (Corsi, 1988).

Pedreira (1973), estudando o crescimento estacional de vários capins durante os anos agricolas de 1965/66 à 1969/70, obteve as produções médias anuais de Colonião entre 8,8 e $13,4 \mathrm{t} \mathrm{MS} \mathrm{ha}^{-1}$ ano $^{-1}$ e observou que a produção média de matéria seca do inverno correspondeu a cerca de $9 \%$ da produçào anual.

O estabelecimento de pastagens com ecotipos superiores para a produção de matéria seca no período seco pode permitir aumentos significativos na lotação das pastagens, mas não resolve os problemas decorrentes da estacionalidade de produçào, ou seja, a lotação animal nas pastagens estabelecida pelos níveis mais baixos de produtividade da forragem, a ocorrência de pastejo desuniforme, o aparecimento de áreas super pastejadas que se transformam em focos de degradação, e o aparecimento de áreas sub-pastejadas, ocasionando grandes perdas (Corsi, 1988). 


\subsection{Adubaçảo}

O nível de fertilidade do solo para exploração de pastagens é um dos principais fatores que interferem no nivel de produção e qualidade da forragem (Corsi \& Nussio, 1993). A correção e ajuste nos niveis dos nutrientes do solo, tanto macro quanto microelementos, assume importância fundamental e deve ser prática considerada indispensável para a exploração racional das plantas forrageiras (Corsi \& Nussio, 1993). Além desse aspecto relacionado aos níveis de nutrientes, deve-se também observar a relação entre eles, de modo que a adubação correta das pastagens figura como tecnologia complexa e indispensável para a manutenção de elevada produtividade das plantas forrageiras.

Alguns trabalhos sugerem que as correções de fertilidade sejam feitas para atingir-se níveis de saturação por bases da ordem de $40 \%$ para as plantas sob pastejo (Werner, 1995), condição esta considerada insatisfatória se o objetivo é maximizar e otimizar a resposta das plantas forrageiras às práticas de fertilização, uma vez que os níveis ideais indicados por outros pesquisadores giram em torno de 60-70\% (Corsi \& Nussio, 1993). A adubação fosfatada, juntamente com adequação dos níveis de saturação por bases trocáveis do solo, assume papel fundamental no estabelecimento de condições ótimas para se atingir o potencial de produtividade dos solos de baixa fertilidade, como são em geral, os solos tropicais. Para o início de trabalho de pastejo intensivo, especialmente em 
solos de baixa fertilidade, recomenda-se elevar o teor de fósforo para cerca de 10 ppm (Corsi \& Nussio, 1993).

A comparação dos efeitos do fósforo na formação da pastagem e em pasto estabelecido de capim-colonião num solo Podzólico Vermelho-Amarelo com teor muito baixo de fósforo foi realizada por Monteiro \& Werner (1977). Esses autores verificaram que o fósforo foi indispensável ao adequado estabelecimento da graminea, enquanto que, no pasto formado, a aplicação de superfosfato simples $\left(500 \mathrm{~kg} \mathrm{ha}^{-1}\right)$ resultou em um aumento de $20 \%$ na produção anual de matéria seca de capim.

Corrêa (1991) cultivou o capim colonião utilizando solo com teor muito baixo de fósforo e constatou respostas expressivas à adubação fosfatada em termos de produção de matéria seca, perfilhamento e teor de fósforo na forrageira. Nesse experimento o autor determinou que houve necessidade de aplicar entre 110 e 300 $\mathrm{kg} \mathrm{ha}^{-1}$ de $\mathrm{P}_{2} \mathrm{O}_{5}$ para obter-se cerca de $90 \%$ da produção máxima.

Gomide (1975) mostrou que o emprego de $40 \mathrm{~kg} \mathrm{P}_{2} \mathrm{O}_{5} \mathrm{ha}^{-1}$, no sulco de semeadura de capim Coloniào, resultou num acréscimo de $46 \%$ na produçào de matéria seca desta forrageira.

Trabalhos de pesquisa de Martinez (1980) e Monteiro (1990) demonstraram que níveis críticos de fósforo no solo para assegurar máxima resposta das plantas forrageiras estava em torno de 20-30 ppm.

O nitrogênio é, sem dúvida, um dos elementos mais ausentes no solo e possui papel fundamental na modulação das respostas às adubações pelas plantas. A maior eficiência em seu uso, assim como as melhores respostas em termos de produção, somente ocorrerão 
quando os demais nutrientes encontrarem-se em equilibrio na solução do solo de forma a gerar um ambiente ótimo para os processos de absorção por parte da planta. As adubações nitrogenadas devem ser parceladas durante o período das águas com o objetivo de melhorar a eficiência de utilização pela planta. Após a eliminação do meristema apical pelo corte ou pastejo, a produção de matéria seca é determinada pela expansão das folhas, a qual depende das condições climáticas e disponibilidade de nitrogênio, justificando, deste modo, a adubação com nitrogênio imediatamente após o corte. (Corsi \& Nussio, 1993).

Caro - Costa \& Vicente Chandler (1961) testando diferentes tipos de adubação, obtiveram aumento de rendimento da forragem com adubações de até $450 \mathrm{~kg} \mathrm{~N} \mathrm{ha}^{-1} \mathrm{ano}^{-1}$.

Favoreto et al. (1988) empregaram níveis de nitrogênio de $0 ; 50$ e $100 \mathrm{~kg} \mathrm{ha}^{-1}$ em capim Colonião, avaliando as respostas em termos de produção de matéria seca durante o período de verão (NovembroMarço). Constataram aumento significativo na produção de matéria seca e determinaram que as taxas de acúmulo de matéria seca do capim aumentaram de 47 para 68 e $83 \mathrm{~kg} \mathrm{ha}^{-1} \mathrm{dia}^{-1}$ com os respectivos incrementos das doses desse nutriente.

Encontra-se na literatura correlação linear entre a produção de matéria seca e o nível de adubação nitrogenada até doses de 400 a $800 \mathrm{~kg} \mathrm{~N} \mathrm{ha}^{-1} \mathrm{ano}^{-1}$, sendo a eficiência de resposta variável entre 40 e $70 \mathrm{~kg} \mathrm{MS} \mathrm{kg}^{-1}$ de $\mathrm{N}$ aplicado. Dessa forma, se a demanda for dimensionada e considerando-se perdas por pastejo, pode-se calcular a quantidade de nitrogênio a ser utilizada (Corsi \& Nussio, 1993). 
Gomide (1984) apresentou resultados de vários experimentos com capim colonião em que a eficiência de conversão de nitrogênio em produção de matéria seca atingiu até $32 \mathrm{~kg} \mathrm{MS} \mathrm{kg}^{-1} \mathrm{de} \mathrm{N}$.

A aplicação de nitrogênio $\left(150 \mathrm{~kg} \mathrm{ha}^{-1} \mathrm{ano}^{-1}\right)$ em uma área com capim colonião, foi realizada por Monteiro \& Werner (1977), que obtiveram aumento significativo na produção de matéria seca durante o ano. Dos resultados apresentados pôde-se verificar que, na média de cinco períodos de crescimento avaliados durante todo o ano, a taxa de acúmulo de matéria seca do capim aumentou de 14 para $31 \mathrm{~kg}$ MS ha ${ }^{-1}$ dia $^{-1}$ como conseqüência da adubação nitrogenada. Também, a relação entre quilogramas de matéria seca do capim por quilograma de nitrogênio aplicado foi de 27,9 .

Monteiro \& Werner (1994) discutiram vários aspectos relacionados à reciclagem do potássio em áreas submetidas a pastejo, considerando excreções animais, retorno através da reciclagem de partes das plantas forrageiras e da contribuição da suplementação alimentar dos animais. A recomendação de adubação com potássio para pastagens com Panicum tem sido feita com base na análise de solo. Na formação da pastagem, quando o teor de potássio trocável no solo é muito baixo, aconselha-se a aplicação de $60 \mathrm{~kg} \mathrm{~K}_{2} \mathrm{O} \mathrm{ha}^{-1}$. Para pastagens formadas os níveis de adubação são de 60 ou $30 \mathrm{~kg}$ $\mathrm{ha}^{-1}$, para casos de teores muito baixo/baixo ou médio, respectivamente.

Por outro lado, o nível de adubação com potássio também é recomendado com base na CTC do solo. Assim, Corsi \& Nussio (1993) indicaram que a adubação potássica deveria ser no sentido de atingir $4 \%$ de potássio na CTC. 
Para efeito de cálculos para recomendação de adubação, podese considerar que entre 30 a $50 \%$ do $\mathrm{K}$ é reciclado sob pastejo (Corsi \& Nussio, 1993).

\subsection{Perfilhamento}

Pastagens de Panicum de alta produtividade parecem requerer, para o sucesso do manejo, o uso do "sistema" rotacionado ou, pelo menos, o "sistema" alternado de uso do pasto. Esse fato se deve à característica de perfilhamento dessa planta (Corsi, 1984b).

Certamente o manejo de pastagem baseado no perfilhamento deve ser estudado para o Panicum, uma vez que este princípio de manejo permite a exploração dessa planta através de elevados níveis de fertilidade do solo, com perdas baixas, isto é, elevada eficiência de pastejo e boa qualidade de forragem disponivel. (Corsi \& Santos, 1995).

Hodgson (1990) entende que o perfilho é a unidade básica da produção de gramíneas. Este tem a capacidade para desenvolver novas gerações de perfilhos oriundos de cada uma de suas folhas individuais.

Durante o crescimento de uma pastagem, a produção de matéria seca aumenta devido ao aumento no peso e no número dos perfilhos Dourat et al. (1980) citados por Rodrigues \& Reis (1995).

Boonman (1971) e Loch (1980) mostraram que o máximo de perfilhamento ocorre durante a fase inicial do crescimento vegetativo. 
Corsi (1984a) determinou que a gramínea Panicum maximum desenvolveu todos os perfilhos até 8 dias após o corte, sendo que foi insignificante o número de perfilhos após o $16^{\circ} \mathrm{dia}$.

A produção de novos perfilhos é normalmente um processo intermitente que pode ser disparado pela desfolha das plantas e, consequentemente, melhoria da iluminação na base do pasto (Hodgson, 1990). Perfilhos individuais têm um determinado tempo de vida que pode ser de mais de um ano ou apenas algumas semanas. Assim, para a população poder ser mantida, existe a necessidade de substituição contínua para a perenização do pasto (Hodgson, 1990).

Gomide et al.(1979) comentaram sobre a importância do peso dos perfilhos na produção de matéria seca do capim Colonião, relatando que a eliminação de $1 / 3$ dos meristemas apicais foi suficiente para provocar redução significativa no vigor da rebrota dessa planta. Reveste-se de importância o cuidado de preservar os meristemas apicais de capins do gênero Panicum em determinadas épocas do ano devido ao fato de que o perfilhamento pode ser prejudicado por condições climáticas e/ou edáficas. Neste caso, a produção de matéria seca dependeria dos perfilhos existentes que, para se manterem vivos, não poderiam ter seu meristema apical decapitado.

O capim colonião representa uma espécie forrageira com baixo potencial de perfilhamento, como determinaram Nascimento et al. (1980) citados por Corsi (1988), concluindo que deve requerer um manejo que preserve seus meristemas apicais. Explica-se desse modo a preferência por espécies forrageiras tardias, aquelas que elevam o 
meristema somente no final da estação de crescimento, como o Tobiatã. Corsi (1988) relata as limitações do manejo das pastagens, baseado na preservação do meristema apical em pastagens de alta produtividade, pois o emprego de adubações para manter a produtividade elevada, provoca a elevação do meristema apical e sua eliminação durante o pastejo. Produtividades elevadas podem ser obtidas com plantas de reduzida capacidade de perfilhamento, desde que sejam exploradas através do peso dos perfilhos. A exploração dessa característica, no entanto, exige maiores períodos de descanso, que nem sempre são desejáveis devido à senescência da forragem, aumento nas perdas e declínio na qualidade (Coesi, 1988).

Corsi (1984a), trabalhando com Panicum maximum, demonstrou que adubações, principalmente nitrogenadas, concorreram para acelerar a elongação das hastes, observando que, quando as desfolhações ocorreram a cada três semanas, a porcentagem de meristemas apicais eliminados aumentava de $32,8 \%$ para $62,2 \%$ nas plantas adubadas com níveis baixos e altos de nitrogênio, respectivamente. Para o intervalo de cinco semanas entre desfolhações esses valores eram de $64,5 \%$ e 89,1 respectivamente, para os níveis baixos e altos de adubações com nitrogênio.

Estudo de crescimento contínuo de gramíneas tropicais revelou que o número de perfilhos caiu com o avanço da idade da planta, queda essa que devida à competição entre os perfilhos por luz (Andrade, 1987).

Singh \& Chatterjee (1968) afirmaram que os fatores de crescimento como luz, temperatura e umidade, são essenciais para o perfilhamento, porém, com a contínua disponibilidade desses fatores, 
ocorre o alongamento e desenvolvimento desses perfilhos que resultam numa redução da atividade de perfilhamento da planta.

Pedreira (1975) relatou que o perfilhamento ocorre de forma estacional, sendo baixo no terço final de verão, atribuído ao sombreamento verificado na base da planta e pela dominância apical desses perfilhos. A atividade de perfilhamento também é baixa em meados de maio devido ao florescimento.

Pedreira (1965/66) citado por Pedreira (1972) registrou para o capim colonião em crescimento contínuo, $312 ; 243 ; 109 ; 93 ; 83 ; 111$ e 68 perfilhos $\mathrm{m}^{-2}$, respectivamente para as idades de $26 ; 50 ; 68 ; 89$; $110 ; 132$ e 156 dias de crescimento, observando queda acentuada do número de perfilhos com a idade da planta forrageira.

Pedreira (1973), em trabalho sobre a estacionalidade de produção de matéria seca de cinco gramíneas forrageiras, verificou que no capim Colonião o número de perfilhos no verão não era estatisticamente diferente do número de perfilhos no inverno. Todavia, o peso individual dos perfilhos no verão era superior ao peso observado durante o inverno. Essa situação levou o autor a sugerir que, para o capim colonião, a produtividade estava relacionada com o peso individual de cada perfilho e não com o seu número.

Hodgson (1990) relatou que uma maior densidade de perfilhos corresponde um menor peso por perfilho e uma menor taxa de alongamento das folhas.

Corsi (1988) sugere que o manejo de pastagens de alta produtividade de Panicum maximum, é aquele onde se estabeleçe o pastejo uniforme da área. As características de perfilhamento, 
associadas ao elevado potencial produtivo do Panicum maximum, sugerem que o pastejo rotacionado, ou suas variações, é mais benéfico do que o pastejo contínuo para alcançar qualidade, produção e uniformidade no uso da pastagem. O manejo baseado somente na preservação do meristema apical, que se ajusta às exigências das variedades tardias, pode limitar a exploração de pastagens de elevada produtividade, principalmente quando adubos nitrogenados são usados.

Corsi (1984a) relatou que o aumento no perfilhamento, como conceito de recuperação de pastagens através da formação de maior quantidade de folhas novas, é muito pouco explorado em nossas condições. O crescimento de folhas e o perfilhamento são áreas prioritárias de estudos para se estabelecer técnicas de manejo objetivando altas produções. O perfilhamento, o alongamento de folhas e hastes são considerados os sítios metabólicos mais ativos na planta forrageira e, desse modo, quando explorados intensivamente, permite elevada eficiência fotossintética e condições de alta produção 


\subsection{Fluxo de tecidos}

O fluxo de matéria seca da parte aérea de um pasto pode ser estudado através das taxas de síntese e morte de tecidos por perfilho aliadas à estimativas do número de perfilhos por área (Davies, 1993). Outra medida do fluxo de tecido foliar pode ser feita através do filocrono e da longevidade das folhas e/ou das taxas de expansão foliar e da senescência (Santos, 1997).

Filocrono foi definido por Wihelm \& McMaster (1995) como o intervalo de tempo entre o mesmo estádio de crescimento em duas folhas sucessivas. O filocrono pode ser influenciado por diversos fatores: temperatura (Collins \& Jones, 1988), genótipo (Pinto et al, 1994), nutrientes (Vine, 1983), estação do ano (Barbosa et al., 1996) e intensidade da desfolha (Grant et al., 1981).

O aparecimento, crescimento e morte das folhas em uma planta dependem de fatores genéticos (espécie, variedades) e do meio (temperatura, umidade, fotoperíodo, intensidade luminosa, nutrição mineral, presença de patógenos, etc) (Thomas \& Stoddart, 1980; Anslow, 1996).

A taxa de alongamento de folhas é um parâmetro morfológico de extrema importância para a avaliação de gramíneas, devido a sua forte correlação com variáveis ligadas à produtividade da forrageira. A expansão das folhas é responsável por $80 \%$ do seu crescimento, $95 \%$ do aumento do seu peso seco e $99 \%$ da área foliar (Hay \& Walker, 1989).

Estudando o efeito da freqüência de corte e de doses de nitrogênio sobre o alongamento das folhas de azevém perene, Pearse 
\& Wilman (1984) observaram que à medida em que o intervalo entre cortes aumentou ( $1,2,3$ e 4 semanas), a taxa de alongamento de folhas sofreu acréscimos em níveis decrescentes $(6,7 ; 7,8 ; 9,0$ e 9,5

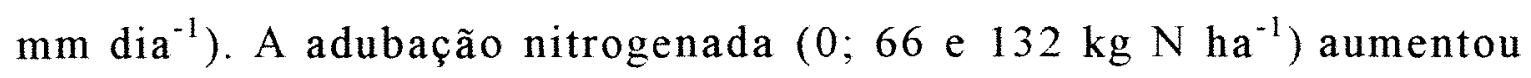
as taxas de alongamento $\left(4,2 ; 8,0212,5 \mathrm{~mm} \mathrm{dia}^{-1}\right.$, respectivamente).

A senescência é um processo de deterioração que acompanha o envelhecimento e leva à morte de um órgão ou organismo. Ela é geneticamente programada para cada espécie e para os órgãos e tecidos de cada planta é influenciada pelo meio ambiente (Salisbury \& Ross, 1992). Nas folhas, a senescência é acompanhada por perdas de clorofila, RNA e proteínas, incluindo enzimas (Salisbury \& Ross, 1992). De forma semelhante ao que foi verificado para a expansão foliar, o $\mathrm{N}$ é considerado o principal nutriente relacionado à senescência (Thomas \& Stoddart, 1980). 


\subsection{Freqüência de corte, período de ocupação e índice de área foliar remanescente}

Após a desfolhação, metabólitos e/ou fotoassimilados necessários para a produção de novos perfilhos, folhas e raízes provém da fotossíntese ou de reservas acumuladas nas raízes e pontos de crescimentos. As reservas são de grande importância quando a área foliar residual é pequena e/ou quando sua eficiência fotossintética é baixa (Broughan, 1957; Korte \& Harris, 1987).

Estudos sobre o efeito de fatores morfológicos sobre a rebrota do capim colonião determinaram que o teor de carboidratos não estruturais na base do caule estava recuperado entre 14 e 21 dias após o corte, concluindo que o vigor da rebrota dessa gramínea não está relacionado com os teores de carboidratos não estruturais, mas ao número de meristemas apicais remanescentes após o corte (Gomide et al., 1979).

Hay \& Walker (1989) indicaram que a taxa de expansão de folhas é responsável por $80 \%$ do crescimento em comprimento, $95 \%$ do peso seco e $99 \%$ da área foliar. Desse modo, fica caracterizado que espécies forrageiras que apresentam taxa de elongação mais elevadas dependem de reservas de carboidratos por menor período de tempo durante a rebrota.

No sistema de pastejo baseado no índice de área foliar remanescente e preservação do meristema apical, normalmente a altura de pastejo é mais elevada e, consequentemente, os níveis de perdas são altos. Práticas agronômicas podem afetar tanto o processo de crescimento (folhas, perfilhos, raizes), como o de morte, 
senescência e decomposição, concluindo que essas práticas agronômicas devem ser manipuladas de forma a permitir rápido restabelecimento da área foliar, associado à redução nas perdas por senescência (Korte \& Sheath, 1979).

Regimes de desfolhações mais freqüentes e intensas, por corte ou pastejo, geralmente reduzem o crescimento da pastagem mas nem sempre reduzem a quantidade de forragem colhida. Decréscimos em crescimento com desfolhações mais freqüentes e intensas podem ser total ou parcialmente compensados por utilização melhorada e, portanto, por perdas reduzidas de forragem não colhida (Birchan \& Hodson, 1983; Grant \& King 1983; Korte \& Harris, 1987; L'Huillier, 1987).

As variedades precoces devem ser manejadas com maior freqüência de corte do que as variedades tardias devido às suas características de florescimento constante, além de exigirem melhoras sensíveis nos níveis de fertilidade do solo (Corsi, 1988).

Maiores taxas de aparecimento de folhas associadas a elevadas taxas de alongamento proporcionam condições para formação rápida de área foliar durante a rebrota (Corsi et al., 1994). O equilíbrio entre o aparecimento e a morte de folhas nos perfilhos pode definir o intervalo "ótimo" entre pastejos do ponto de vista da planta. Assim, o número médio de folhas por perfilho no ponto de equilíbrio entre aparecimento e senescência, multiplicado pela taxa de aparecimento (dias por folha), definiria o tempo necessário para a recuperação da planta após o pastejo (Corsi et al., 1994). 
Pedreira (1972) trabalhando com capim colonião, no período de outubro a março, obteve a taxa média de acúmulo de $67 \mathrm{~kg} \mathrm{MS}$ dia $^{-1}$, quando o intervalo médio entre os cortes, a $10 \mathrm{~cm}$ do solo, foi de 37 dias.

Quando o pastejo ocorre após longos períodos de descanso há uma redução na eficiência de utilização da forragem produzida, uma vez que o longo período de descanso favorece o acúmulo de resíduo deixado após o pastejo e, como conseqüência, reduzem a digestibilidade da matéria seca oferecida (Maraschin, 1986).

Furlan (1969) determinou que o capim Colonião apresentou melhores respostas quanto a produção de matéria seca e qualidade de forragem quando foi submetido à freqüência de 35 dias entre cortes e com período de ocupação correspondente a 7 dias. Esse autor apontou que o período de corte de 21 dias prejudicou a resposta da planta quanto a produção de forragem, e que o corte freqüente, mesmo que executado com intensidade baixa, pode levar as pastagens de capim Colonião a degradação.

Corsi (1988) relatou que 5 a 6 semanas de intervalo entre pastejos possibilitaram excelentes condições para o uso de pastagens de capim Colonião e de variedades tardias de Panicum.

Watkins \& Severen (1951) concluíram que seria possivel recomendar o corte do colonião a intervalos de 6 a 8 semanas na altura de $30 \mathrm{~cm}$.

No caso de plantas eretas, melhores rebrotas são possíveis quando os períodos de pastejo são de curta duração (3-8 dias), pois permitem melhor controle de condições do resíduo para valores desejáveis de IAF e de carboidratos de reserva (MARASCHIN, 1986). 
Para eliminar os resíduos deixados após o pastejo, seria necessário trabalhar com alta pressão de pastejo para forçar o consumo de toda matéria seca disponível (MARASCHIN, 1986).

Jones \& Carabaly (1981) citados por Rodrigues \& Reis (1995) concluíram que a manutenção de cobertura vegetal adequada, evitando a desfolhação excessiva em gramíneas tropicais com hábito de crescimento cespitoso, é um fator importante para a manutenção de rebrotas adequadas, já que a área foliar residual foi correlacionada positivamente com a rebrota durante as primeiras três semanas após a desfolhação.

De maneira geral tem sido preconizado que as pastagens devem ser manejadas de forma a permitir-se a pronta recuperação das plantas pastejadas. Embora se reconheça que a manutenção de um IAF ótimo sob condições de pastejo seja praticamente impossível, é razoável admitir que o crescimento de plantas será reduzido com a manutenção de um IAF baixo devido à inadequada interceptação de luz pelas plantas. Por outro lado, o acúmulo de matéria seca também será reduzido com a manutenção de valores elevados de IAF em decorrência do aumento na atividade respiratória e da acelerada senescência de folhas (Hodgson, 1990). 


\subsection{Perdas de forragem por pastejo}

A forragem disponivel numa determinada pastagem pode ter destinos diversos em função do manejo: pode ser ingerida pelo animal em pastejo, cumprindo seu papel de fonte de nutrientes para o herbívoro; deixada como resíduo pós-pastejo para que contribua para a captação de luz e fotossíntese, necessária para início da rebrota e, finalmente, pode ser totalmente perdida seja através do pisoteio, contato com dejeções animais ou pela senescência do tecido vegetal (Hillesheim, 1987)

As práticas de manejo de pastagem devem também visar a maximização do consumo de MS, reduzindo ao máximo possíveis perdas de forragem e material remanescente sem, no entanto, prejudicar a perenidade ou a produtividade dessa pastagem (Hodgson, 1990).

Combellas \& Hogdson (1979) observaram uma redução na eficiência de pastejo de azevém perene avaliada através da proporção consumida da matéria seca disponível da forragem. Assim, à medida que a disponibilidade de forragem animal ${ }^{-1}$ aumentou para $30,60 \mathrm{e}$ $90 \mathrm{~g} \mathrm{MS} \mathrm{kg}^{-1}$ de peso vivo (PV) o consumo foi de 85,49 e $33 \%$ da forragem em oferta, respectivamente. A ingestão máxima de forragem por animal foi obtida com uma disponibilidade de forragem próxima ao dobro do consumo animal.

A disponibilidade de forragem por peso animal é um parâmetro de manejo que influi de forma significativa nas relações de produção, consumo e perda de forragem em uma pastagem. Para determinada oferta de forragem por animal, foram observadas alterações 
significativas no desempenho animal quando a disponibilidade de forragem ( $\mathrm{kg} \mathrm{MS}\left(100 \mathrm{~kg} \mathrm{PV}^{-1}\right)$ foi regulada, com conseqüente variação da quantidade de resíduo pós-pastejo.

Hillesheim (1987) concluiu que as perdas de forragem em capim elefante são determinadas por diferentes variáveis. A cada 1 $\mathrm{cm}$ de elevação na altura do meristema apical houve acréscimo de $49,4 \mathrm{~kg}$ de matéria seca na perda de forragem através do pastejo. Já a quantidade de folhas do material foi inversamente correlacionada com as perdas, reduzindo-se em $470 \mathrm{~g} \mathrm{MS} \mathrm{ha}^{-1}$ para cada unidade percentual de aumento de folhas na planta. Da mesma forma Hilleshein (1987) determinou que o resíduo pós-pastejo aumentou (2680,5460, e $4902 \mathrm{~kg} \mathrm{MS} \mathrm{ha}^{-1}$ ) com o acréscimo na disponibilidade de forragem por animal (4, 8 e $12 \% \mathrm{PV}$, respectivamente).

Wilson \& Mannetje (1975) citados por Rodrigues \& Reis (1995) mostraram que, em decorrência dos animais pastejarem seletivamente as folhas, a investigação sobre suas taxas de crescimento e senescência, bem como as mudanças na composição morfológica e digestibilidade das mesmas, são indicadores para se entender mudanças que afetam a qualidade da forragem ingerida por animais em pastejo.

Rodrigues \& Reis (1995) relataram que é notória a falta de dados sobre a senescência e morte de folhas na espécie Panicum maximum submetida ao pastejo, e enfatizam o fato de que essas informações contribuiriam para aprimorar o manejo dessas plantas através da redução das perdas de forragem e da melhoria da qualidade de forragem disponível. 


\subsection{Qualidade da forragem}

A disseminação e elevada aceitação do capim colonião entre os pecuaristas, apesar de sua elevada estacionalidade de produção, talvez seja justificada pelo elevado teor de proteína (Corsi \& Santos, 1995).

Modificações na qualidade da forragem ocorrem com aumentos no período de descanso, o que afeta a utilização da forragem pelo animal em pastejo. Ball et al.(1991) citados por Rodrigues \& Reis (1995), relataram que as folhas mais velhas têm eficiência fotossintética reduzida e podem entrar em senescência e morrer. Assim, fica evidente que o método de pastejo deve permitir o consumo de folhas antes que ocorra a senescência, de modo a obterse o melhor valor nutricional da planta com o mínimo de perdas decorrentes do pastejo.

A expectativa de aumentar o teor de proteína na planta através da adubação nitrogenada deve ser analisada com reserva uma vez que, dependendo do período de tempo ou condições para metabolismo, a aplicação do nitrogênio repercute em aumento da matéria seca sem interferir na concentração de nitrogênio na matéria seca (Corsi \& Nussio, 1993). Geralmente, verifica-se melhora na qualidade da matéria seca com adubações nitrogenadas em função da produção de maior massa foliar, perfilhos novos e longevidade das folhas. Nestas condições, a melhora de qualidade se traduz por maior consumo voluntário de matéria seca, questionando-se, assim, a validade da identificação de qualidade somente pelo teor de proteína da planta forrageira (Corsi \& Nussio, 1993). 
Pedreira \& Silveira (1972) estudando o capim Colonião obtiveram $30,7 \% ; 30,5 \% ; 22,1 \% ; 17,7 \% ; 16,6 \% ; 14,9 \% ; 12,6 \%$; $14,6 \% ; 12,9 \% ; 12,6 \% ; 11,1 \% ; 8,9 \%$ e $7,7 \%$ de PB aos $26,31,39,50$, $55,60,68,75,80,89,110,132$ e 152 dias de idade, respectivamente. Andrade (1987) obteve $19,05 \% ; 16,2 \% ; 12,6 \% ; 9,3 \% ; 8,95 \%$; $5,7 \% ; 6,6 \% ; 4,95 \%$ e $4,25 \%$ de PB na parte aérea do capim Colonião colhido aos $28,56,84,112,140,168,224$ e 252 dias de idade, respectivamente. Em outro capim da mesma espécie, o Tobiatã, cortado nas mesmas idades do colonião, os valores obtidos foram $18,15 \% ; 12,9 \% ; 8,7 \% ; 9,45 ; 8,85 \% ; 4,75 * 6,3 \% ; 6,2 \% ;$ e $3,95 \%$ de PB. Esse autor observou ainda que o teor de fibra em detergente neutro aumentava com a idade de corte.

Euclides (1995) estudando diversos cultivares de Panicum maximum, concluiu que valores de FDN inferiores a $55 \%$ são raros. Valores superiores a $65 \%$ são comuns em tecidos novos e teores entre 75 a $80 \%$ são encontrados em materiais de maturidade avançada.

Segundo Corsi (1988), o potencial elevado de produção de matéria seca por unidade de área das forragens tropicais e a homogeneidade da idade cronológica de seus perfilhos fazem com que estas percam qualidade muito rapidamente com a maturidade, assim como elevem a sua relação haste:folha, o que acarreta em um menor consumo voluntário e decréscimo de seu valor alimentício quando colhidas em época imprópria.

As maiores mudanças que ocorrem na composição química das forrageiras são aquelas decorrentes da maturação da planta. À medida que a planta amadurece, a produção dos componentes potencialmente digestíveis, compreendendo os carboidratos solúveis, proteínas, 
minerais e outros conteúdos celulares, tende a decrescer. Ao mesmo tempo, a proporção de lignina, da celulose e hemicelulose e de outras frações indigestíveis, tais com a cutícula e a sílica, aumentam. Consequentemente, decréscimo na digestibilidade são esperados (Euclides, 1995).

As taxas de decréscimo na digestibilidade durante o crescimento de gramíneas do gênero Panicum são superiores às apresentadas por outras gramíneas tropicais, e da ordem de 0,1 unidade percentual por dia. Provavelmente isto se deve às altas digestibilidades iniciais apresentadas pelo Panicum (Minson, 1971).

Rocha (1979) observou decréscimo na digestibilidade "in vitro" da matéria seca (DIVMS) com o avanço da idade nos capins analisados. No capim green-panic a DIVMS foi $72,1 \% ; 67,8 \% ; 62,0 \%$ e $52,8 \%$, já em capim sempre-verde os valores obtidos foram: $61,4 \% ; 56,2 \% ; 49,6 \%$ e $42,9 \%$, respectivamente, para cortes efetuados aos $21,42,63$ e 84 dias de crescimento.

Vieira (1979) obteve os seguintes teores médios de digestibilidade "in vivo" da matéria seca: $86,95 \% ; 85,32 \% ; 76,26 \%$ e $73 \%$ para folha, e $90,69 \% ; 79,42 \% ; 75,42 \%$ e $64,30 \%$ para haste, quando a planta foi colhida aos $30,45,60$ e 75 dias de idade, respectivamente. Esse autor observou um decréscimo mais acentuado para haste do que para folha durante o período de estudo, chegando à mesma conclusão de outros pesquisadores, ou seja, a digestibilidade da matéria seca diminui com o avanço da idade da planta.

Andrade (1987) obteve em capim colonião 66,9\%; 61,0\%; $55,15 \% ; 45,6 \%$ e 42,6 de DIVMS, e em Tobiatã $66,35 \% ; 57,4 \%$; 
$46,65 \% ; 45,80 \%$ e $41,50 \%$ aos $28,56,84,112$ e 140 dias de idade, respectivamente.

As maiores produções de matéria seca por unidade de área podem ser obtidas com maiores periodos de descanso, que nem sempre são desejáveis devido ao aumento das perdas e declínio na qualidade da forragem, concluindo que deve haver um equilibrio destes fatores que são inversamente correlacionados.

\subsection{Produtividade animal}

O uso de novos cultivares de Panicum maximum tem proporcionado sensiveis melhoras nos índices de produtividade animal. Euclides (1995), trabalhando com ganho de peso vivo por animal por área e taxas de lotação em pastagens de Panicum maximum, nos cultivares Colonião, Tobiatã e Tanzânia 1 adubados com 400 e $800 \mathrm{~kg} \mathrm{~N} \mathrm{ha}^{-1}$, observou ganho de peso de $280,405,445$ $\mathrm{kg} \mathrm{ha}^{-1} \mathrm{ano}^{-1}$ para a dose mais baixa e 370,600 e $645 \mathrm{~kg} \mathrm{ha}^{-1}$ ano $^{-1}$ para a dose mais alta, respectivamente.

Trabalhos conduzidos em condições tropicais demonstraram que a aplicação de nitrogênio aumenta a produção de matéria seca das gramíneas, bem como o ganho de peso de animais em pastejo (Quinn et al., 1961; Mattos \& Wener, 1979).

Favoreto et al., (1985) avaliaram o ganho de peso vivo de bovinos da raça Guzerá com idade de 12 a 15 meses e peso médio inicial de $210 \mathrm{~kg}$, submetidos ao pastejo em áreas estabelecidas com capim Colonião não adubado (testemunha) e adubado com $100 \mathrm{~kg} \mathrm{ha}^{-1}$ 
de nitrogênio. O método de pastejo foi o rotacionado, submetendo os animais a pesagem a cada 35 dias. O trabalho foi realizado durante duas estações chuvosas e uma seca ( 16 meses). Os resultados de 16 meses de avaliação de ganho de peso mostraram uma maior produtividade animal em pastagens adubadas de Colonião $(638,67 \mathrm{~kg}$ $\mathrm{ha}^{-1}$ em 16 meses) em relação as áreas não adubadas $\left(550,77 \mathrm{~kg} \mathrm{ha}^{-1}\right.$ em 16 meses). 


\section{MATERIAL E MÉTODOS}

O experimento foi instalado e conduzido no Centro de Pesquisa de Pecuária do Sudeste - EMBRAPA, município de São Carlos - SP (latitude $22^{\circ} 01^{\prime} \mathrm{S}$, longitude $47^{\circ} 53^{\prime} \mathrm{W}$ e altitude de $854 \mathrm{~m}$, no período de novembro de 1996 a janeiro de 1998. A área experimental era de 8 ha estabelecida com Panicum maximum cv Tanzânia 1, em solo classificado como Latossolo Vermelho Amarelo de baixa fertilidade com as seguintes características químicas: $\mathrm{pH}$ em $\mathrm{CaCl}_{2}=$ 6,6 , matéria orgânica $=2,9 \%, \mathrm{P}($ resina $)=19 \mathrm{mg} \mathrm{dm}^{-3}, \mathrm{~K}=0,43 \mathrm{meq}$ $100 \mathrm{~cm}^{-3}, \mathrm{Ca}=3,3 \mathrm{meq} 100 \mathrm{~cm}^{-3}, \mathrm{Mg}=2 \mathrm{meq} 100 \mathrm{~cm}^{-3}, \mathrm{H}+\mathrm{Al}=2,8$ meq $100 \mathrm{~cm}^{-3}, \mathrm{Al}=0 \mathrm{meq} 100 \mathrm{~cm}^{-3}, \mathrm{CTC}=8,5 \mathrm{meq} 100 \mathrm{~cm}^{-3}, \mathrm{~V}=$ $67 \%$. Os dados de precipitação e temperatura durante o período experimental podem ser observados na Figura 1.

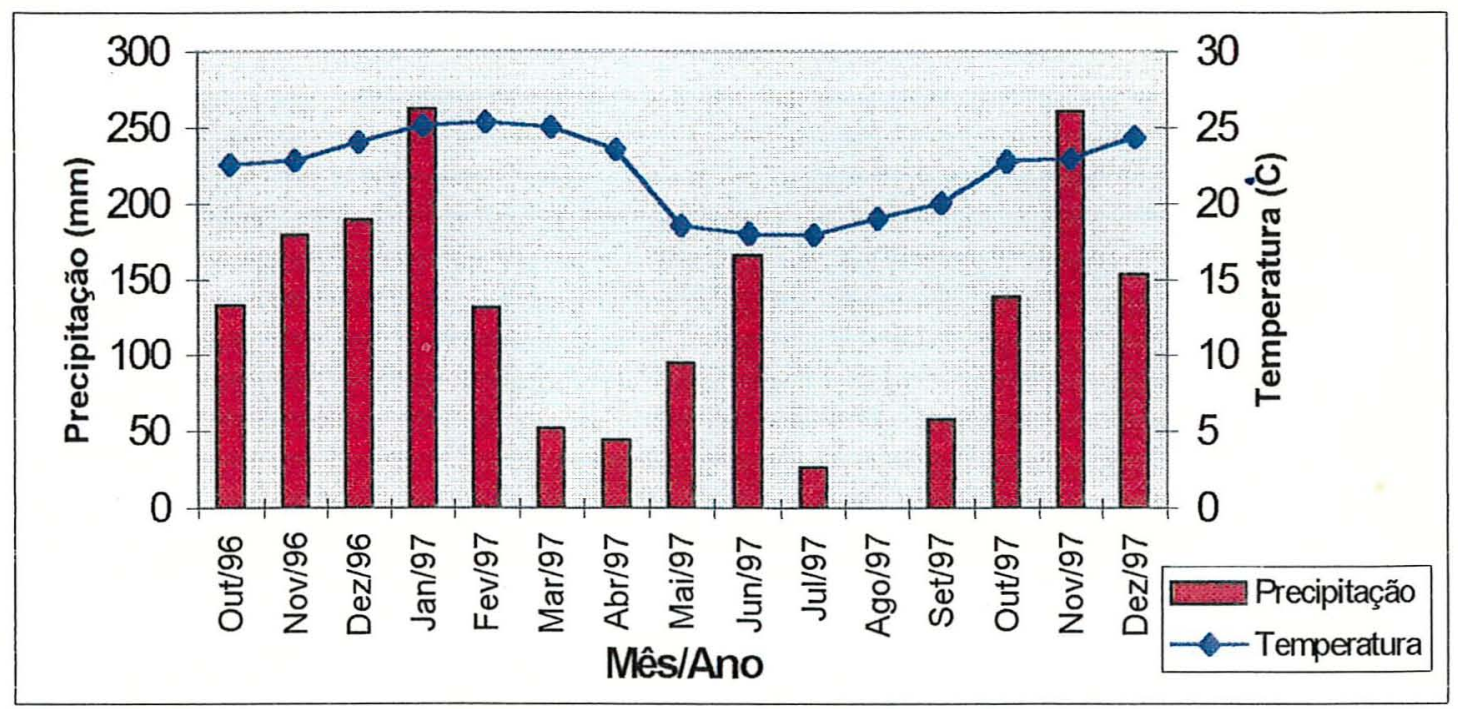

Figura 1. Precipitação $(\mathrm{mm})$ e temperatura média mensal $\left({ }^{\circ} \mathrm{C}\right)$ de outubro de 1996 a dezembro de 1997. 
O método de pastejo utilizado foi o rotacionado com período de descanso e de ocupação de 36 e 3 dias, respectivamente, durante o verão (dezembro a abril, pastejos 1 ao 4 e 8), e 72 e 6 dias de período de descanso e ocupação, durante o inverno (maio a novembro, pastejos 5 ao 7). Para isto a área foi dividida com cerca elétrica em 13 piquetes de aproximadamente $6200 \mathrm{~m}^{2}$ reservando-se uma área central de $1200 \mathrm{~m}^{2}$ onde os animais tinham livre acesso ao saleiro e ao bebedouro. Foi feito um corte de uniformização através de roçadeira em outubro de 1996.

A adubação de cada piquete foi feita em cobertura logo após o pastejo, que era realizado até que a planta forrageira apresentasse altura de resíduo de $35-40 \mathrm{~cm}$. O nível de adubação foi de $320 \mathrm{~kg}$ de $\mathrm{N} \mathrm{ha}^{-1}$ ano $^{-1}\left(80 \mathrm{~kg} \mathrm{~N} \mathrm{ha}^{-1}\right.$ após cada pastejo) utilizando a fórmula 20 - 05 - 20, aplicados no período das águas (dezembro a abril). A taxa de lotação animal era regulada pela adição ou retirada de animais da área experimental. Convencionou-se padronizar a carga animal em "unidade animal" (UA), representada por um animal de $450 \mathrm{~kg}$ de peso vivo. Dividindo-se a somatória do peso dos animais pelo peso padrão da UA e dividindo-se pela área utilizada no período obteve-se a taxa de lotação da pastagem. Foram utilizados 30 e 15 animais "testers" durante o período das águas e seca, respectivamente, que foram pesados sem jejum, com uma freqüência de 10 dias. 


\subsection{Variáveis determinadas}

\subsubsection{Avaliação da produção de matéria seca e taxa de acúmulo de matéria seca}

A produção de matéria seca foi avaliada através do corte, utilizando-se para fazer as amostragens aleatórias um quadrado de $0,25 \mathrm{~m}^{2}(0,50 \mathrm{~m} \times 0,50 \mathrm{~m})$. Foram amostrados três piquetes antes do pastejo em 16 locais, o que corresponde a 26 amostras ha ${ }^{-1}$ ou $6,5 \mathrm{~m}^{2}$ $\mathrm{ha}^{-1}$. A cada lançamento, a forragem do interior do amostrador foi cortada a uma altura de $35 \mathrm{~cm}$ do solo, pesada e sub-amostrada.

As sub-amostras foram pesadas e secas em estufa para determinação da matéria seca. Com esses dados procedeu-se o cálculo de produção de matéria seca por unidade de área, que dividido pelo intervalo entre pastejos resultou nas taxas médias diárias de acúmulo de matéria seca.

\subsubsection{Dinâmica Populacional de Perfilhos}

O perfilhamento foi avaliado em seis unidades de avaliação (touceiras) em um piquete com áreas delimitadas por um quadrado de ferro de $20 \mathrm{~cm}$ de lado. As plantas foram identificadas por idade, utilizando anéis de fios de arame coloridos amarrados na base da haste de cada perfilho. A população de perfilhos basais e aéreos identificada inicialmente com uma única côr foi recontada no pastejo subsequente, sendo os perfilhos sem identificação (novos), identificados com uma nova côr. Essa identificação ocorreu no $5^{\frac{0}{}}$ dia 
após a saída dos animais dos piquetes. Essa metodologia permitiu determinar a dinâmica do perfilhamento.

As memórias dos cálculos para determinação das taxas de aparecimento, mortalidade e sobrevivência dos perfilhos aparecem no apêndice 1 .

\subsubsection{Densidade de perfilhos}

Para o estudo de densidade de perfilhos foi utilizado um amostrador quadrado de $3 \mathrm{~m}$ de lado, lançado três vezes em três piquete após cada período de pastejo, promovendo uma amostragem de $39 \mathrm{~m}^{2} \mathrm{ha}^{-1}$. A cada lançamento foram contados os perfilhos existentes no interior do amostrador, obtendo-se o número de perfilhos $\mathrm{m}^{-2}$ ou por ha em cada período e, com isso, observou-se o comportamento da população de perfilhos ao longo do período experimental.

\subsubsection{Fluxo e renovação de tecidos}

O fluxo de tecidos foi avaliado através da identificação de 6 touceiras e anelamento de 10 perfilhos por touceira Os perfilhos eram marcados com fios de arame coloridos a uma distância praticamente igual um do outro, e esses perfilhos eram dispostos ao longo de uma linha transecta que passava através da touceira. As avaliações foram feitas a cada dois dias no período de 12 dias antes e depois do pastejo, onde se anotava o comprimento das hastes (do 
solo até a lígula da última folha expandida) e o comprimento verde de cada lâmina foliar (da lígula até a ponta ou fim da parte verde, nas folhas expandidas e da lígula da folha anterior até a ponta, nas folhas em expansão). Dessa maneira foi possível calcular:

- Taxa de alongamento foliar ( $\mathrm{cm}$ perfilho ${ }^{-1} \mathrm{dia}^{-1}$ ): calculada através da diferença entre o comprimento final e inicial das folhas em expansão dividida pelo número de dias do período de avaliação.

- Taxa de senescência foliar ( $\mathrm{cm}$ perfilho $\left.{ }^{-1} \mathrm{dia}^{-1}\right)$ : calculada através da diferença entre o comprimento senescente final e inicial dividida pelo número de dias entre as avaliações. O comprimento da parte senescente da lâmina foliar correspondia à redução observada no comprimento verde das folhas, ou seja, uma medida indireta. Desse modo a senescência foi avaliada pela diferença entre medidas consecutivas do comprimento da parte verde da lâmina foliar.

- Taxa de alongamento das hastes ( $\mathrm{cm}$ perfilho ${ }^{-1} \mathrm{dia}^{-1}$ ): calculada pela diferença entre o cumprimento final e inicial das hastes dividida pelo números de dias.

- Número de folhas vivas por perfilho: obtido pela contagem do número de folhas verdes no perfilho. As folhas eram consideradas mortas quando $50 \%$ da área estava amarelecida.

- Aparecimento de folhas: calculado pelo número de dias necessários para uma folha nova aparecer a partir do dia que a ultima folha apareceu.

- Altura do perfilho: obtida através da distância entre a base do perfilho e a ponta da ultima folha completamente expandida.

Foram classificadas cinco categorias de perfilhos em cada ciclo de pastejo a partir dos dados referentes a altura dos perfilhos. Cada 
categoria diferia entre si por uma amplitude de 10 a $15 \mathrm{~cm}$ de altura, dependendo da época de crescimento. Para cada categoria foram escolhidos 10 perfilhos que se encaixassem nesses padrões de alturas. Esses perfilhos foram cortados e levados para o laboratório, onde se separava as hastes, folha 1 , folha 2 , e subsequentes até a última folha existente no perfilho, começando a numeração de baixo para cima, para determinar a relação entre peso e comprimento (mg $\mathrm{cm}^{-1}$ ) Combinando-se estes dados com a taxa de alongamento de folhas e hastes, taxa de senescência e densidade de perfilhos foi possível calcular a taxa de acúmulo. Esses dados foram relacionados com os dados de corte, que avaliaram esta mesma variável.

\subsubsection{Perdas pelo pastejo}

A avaliação das perdas por pastejo foi realizada através de 4 áreas $3 \mathrm{~m} \times 3 \mathrm{~m}$ delimitadas antes de cada pastejo e limpas com o auxílio de um rastelo e manualmente entre as touceiras. O material depositado nestas áreas e sobre as touceiras após cada pastejo foi coletado, pesado e seco, sendo considerada a perda pós pastejo.

\subsubsection{Ganho de peso vivo}

A avaliação do ganho de peso vivo por animal e por ha no período experimental foi realizada pesando 30 e 15 animais "testers" no início e no final do período de "verão" e "inverno", respectivamente, com jejum de 16 horas. Foram utilizados dois lotes de animais machos inteiros puros da raça Canchim. Os animais do 
lote utilizado no período de "verão" apresentaram peso médio de 338 $\mathrm{kg}$ no início da avaliação $(27 / 11 / 96)$ e os utilizados no "inverno" apresentaram peso médio de $258 \mathrm{~kg}$ (29/04/97).

\subsubsection{Análise bromatológica}

A avaliação do valor nutritivo da forragem disponível, foi realizada através de três sub-amostras da forragem utilizada para avaliação da produção de matéria seca. O material foi seco a $60^{\circ} \mathrm{C} \mathrm{em}$ estufa com circulação de ar forçada, por um período de 72 horas. Esse material foi então moído em moinho tipo Wiley, em peneira de $1 \mathrm{~mm}$ de diâmetro e estocadas para realização das análises químicas segundo AOAC (1990): teor de matéria seca a $100^{\circ} \mathrm{C}$ por 24 horas e teor de proteína bruta por micro Keijldahl. A fibra insolúvel em detergente neutro (FDN) foi determinada segundo Goering \& Van Soest (1970). A digestibilidade verdadeira "in vitro" da matéria seca (DVIVMS) foi obtida de acordo com Tilley \& Terrey, (1963), adaptado por Goering \& Van Soest (1970).

\subsection{Análise estatística}

O conjunto de observações foi obtido por amostragem aleatória em área cultivada com Panicum maximum cv Tanzânia 1. As seguintes variáveis foram analisadas:

- Produção de matéria seca;

- Taxa de acúmulo de matéria seca;

- \% Matéria seca; 
- DVIVMS (\%) ;

- FDN (\%);

- PB (\%);

- Ganho de peso;

- Densidade de Perfilhos;

- Perdas pelo pastejo;

- Taxas de aparecimento de perfilhos;

- Taxas de mortalidade de perfilhos;

- Taxas de sobrevivência de perfilhos;

- Taxas de alongamento da haste;

- Taxas de alongamento de folha;

- Taxas de senescência de folhas;

- Número de folhas vivas por perfilho;

- Taxa de aparecimento de folhas.

Foi realizada estatística descritiva, sendo calculada a média aritmética, o desvio padrão e o coeficiente de variação $(\mathrm{CV})$. 


\section{Resultados e Discussão}

\subsection{Produção de matéria seca}

As médias das variáveis produção de matéria seca por pastejo ( $\mathrm{kg}$ MS ha ${ }^{-1}$ ), taxa de acúmulo de matéria seca (kg MS ha ${ }^{-1} \mathrm{dia}^{-1}$ ) durante o período experimental e seus respectivos desvios padrão e coeficientes de variação podem ser observadas na Tabela 1

Tabela 1. Médias de produção de matéria seca por pastejo (kg MS $\left.\mathrm{ha}^{-1}\right)$, taxa de acúmulo de matéria seca ( $\left.\mathrm{kg} \mathrm{MS} \mathrm{ha}{ }^{-1} \mathrm{dia}^{-1}\right)$ e seus correspondentes desvios padrão e coeficientes de variação.

\begin{tabular}{lrrr}
\hline \multicolumn{1}{c}{ Variável } & Média & Desvio & C V \\
& & & \multicolumn{1}{c}{ Padrão } \\
\hline Produção de matéria seca & 3700 & 1908,75 & 51,53 \\
Taxa de Acúmulo de MS & 93,4 & 61,56 & 65,88 \\
\hline
\end{tabular}

Os valores de produção de matéria seca em $\mathrm{kg}$ MS ha ${ }^{-1}$ do capim Tanzânia 1 nos períodos $24 / 12 / 96 ; 02 / 02 ; 14 / 03 ; 24 / 04 ; 27 / 06$; $15 / 09 ; 13 / 11$ e $23 / 12 / 97$ foram respectivamente $5.650 ; 6.603 ; 5.462$; $2.680 ; 2.299 ; 1.684 ; 1.994$ e $3.263 \mathrm{~kg} \mathrm{MS} \mathrm{ha}^{-1}$ (Figura 2).

A produção de matéria seca de forragem avaliada antes de cada pastejo no período de dezembro/96 a dezembro/97, apresenta uma evidente estacionalidade devido aos fatores de crescimento (água, luz e temperatura), atingindo a produção máxima de $6603 \mathrm{~kg} \mathrm{MS} \mathrm{ha}^{-1}$ no mês de fevereiro após um período de 36 dias de descanso, e a mínima 
de $1684 \mathrm{~kg} \mathrm{MS} \mathrm{ha}^{-1}$ no mês de setembro após um período de 72 dias de descanso.

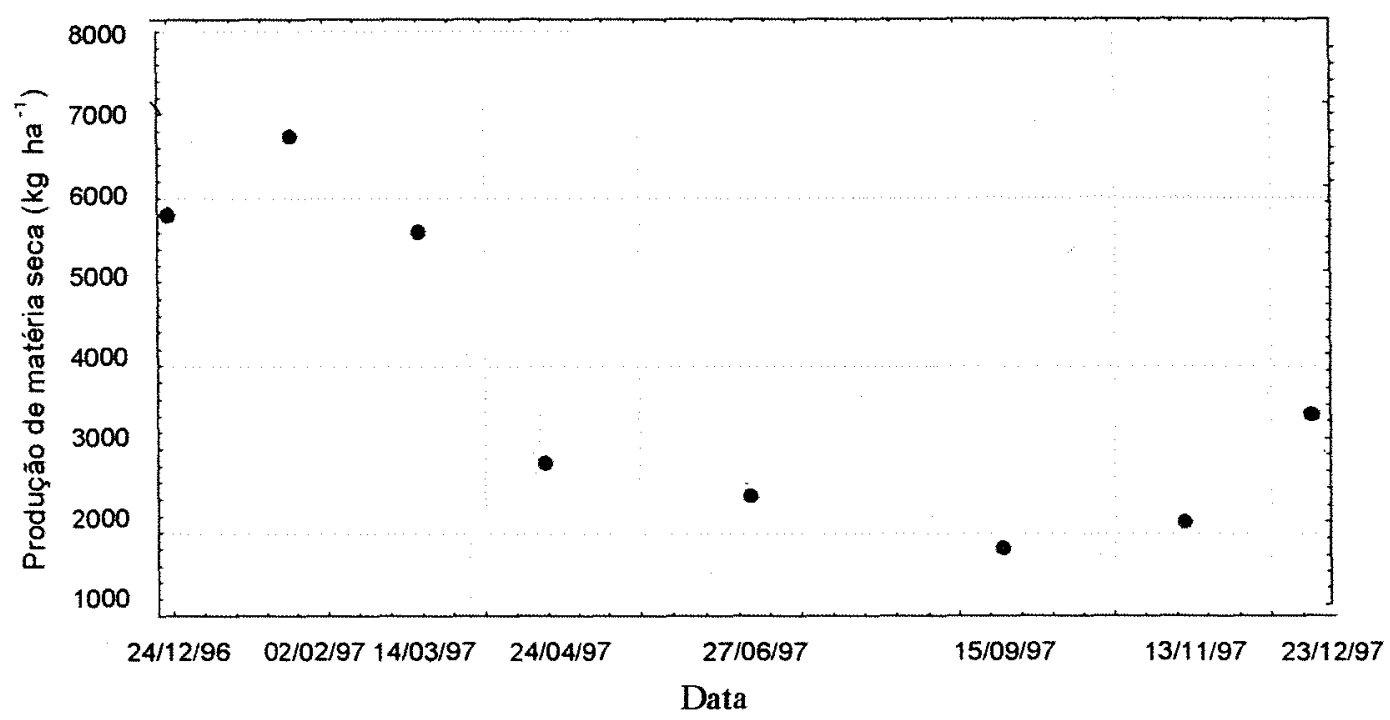

Figura 2. Produção de matéria seca $\left(\mathrm{kg} \mathrm{MS} \mathrm{h}^{-1}\right)$ do capim Tanzânia 1 durante o período experimental de 24/12/96 à 23/12/97.

A produção de matéria seca obtida durante o "verão" e "inverno" foi de 23,6 e 5,9 $\mathrm{t} \mathrm{MS}^{\mathrm{h}} \mathrm{a}^{-1}$, respectivamente.

Em experimento realizado por Cecato et al. (1996) as colheitas foram realizadas a cada 35 dias no "verão" e 70 dias no "inverno" com adubação de reposição efetuada em níveis de $1,5 \% \mathrm{~N}, 2,0 \% \mathrm{~K}$ e $0,3 \% \mathrm{P}$ da produção de matéria seca obtida. A produção total para o capim Tanzânia 1 no "verão" e "inverno" foi de 7,4 e 2,7 t $\mathrm{MS} \mathrm{ha}^{-1}$, respectivamente. Teixeira (1998) trabalhando com capim Tobiatã obteve uma produção total no período de "verão" de 62 t $\mathrm{MS} \mathrm{ha}^{-1}$ com uma adubação de $430 \mathrm{~kg}$ de $\mathrm{N} \mathrm{ha}^{-1} \mathrm{ano}^{-1}$. Herling et al.(1998a) obtiveram com o capim Mombaça sob pastejo, empregando frequêencia de corte a cada 35 dias, uma produção de matéria seca no 
"verão" de 40,6 t MS ha ${ }^{-1}$. Corrêa et al. (1998a) em estudo realizado com 12 gramíneas forrageiras tropicais obtiveram produção de 16,2; 19,$0 ; 18.0$ e 19,2 t $\mathrm{MS} \mathrm{ha}^{-1}$ durante o período de "verão" para os capins B. brizantha, Mombaça, Tanzânia 1 e Tobiatã, respectivamente, utilizando adubação de $400 \mathrm{~kg} \mathrm{~N} \mathrm{ha}^{-1}$. Ruggieri et al. (1997) utilizando o método de pastejo contínuo obtiveram, em quatro cortes num período de 3 meses durante o "verão", uma produção de 3,3 e 6,7 t $\mathrm{MS} \mathrm{ha}^{-1}$ para os capins $\mathrm{B}$. brizantha $\mathrm{e}$ Tanzânia 1, respectivamente. Já Machado et al. (1997) observaram em capim Tanzânia 1 e Tobiatã, cortados a uma altura de $40 \mathrm{~cm}$ a cada 35 e 70 dias, produções de matéria seca da ordem de 16,5 e $19 \mathrm{t}$ MS ha ${ }^{-1} 180^{-1}$ dias no "verão" e de 4,8 e $4,6 \mathrm{t} \mathrm{MS} \mathrm{ha}^{-1} 180^{-1}$ dias no "inverno", respectivamente. No entanto, os níveis de fertilidade do solo e adubação empregados por Machado et al. (1997) foram inferiores aos do presente experimento.

A taxa de acúmulo diário de matéria seca para cada período foi estimada dividindo a produção de matéria seca do período pelos dias de crescimento, utilizando o raciocínio proposto por Balsalobre (1996).

A Figura 3 apresenta uma dispersão para a taxa de acúmulo de matéria seca.

A taxa de acúmulo de matéria seca obtida durante o "verão" e "inverno" foi de 139,6 e $33,5 \mathrm{~kg} \mathrm{MS} \mathrm{ha}^{-1} \mathrm{dia}^{-1}$, respectivamente, atingindo o máximo de $183 \mathrm{~kg} \mathrm{MS} \mathrm{ha} \mathrm{dia}^{-1}$ no mês de fevereiro tendendo a um decréscimo para os periodos subsequentes, e atingindo o acúmulo mínimo de $23 \mathrm{~kg} \mathrm{MS} \mathrm{ha}^{-1} \mathrm{dia}^{-1}$ no período de agosto e setembro (Figura 3). Esse comportamento seguiu a estacionalidade de 
gramíneas tropicais descrita por Machado et al. (1997), Pedreira \& Mattos (1981), Corsi \& Santos, (1995) e Jank (1994).

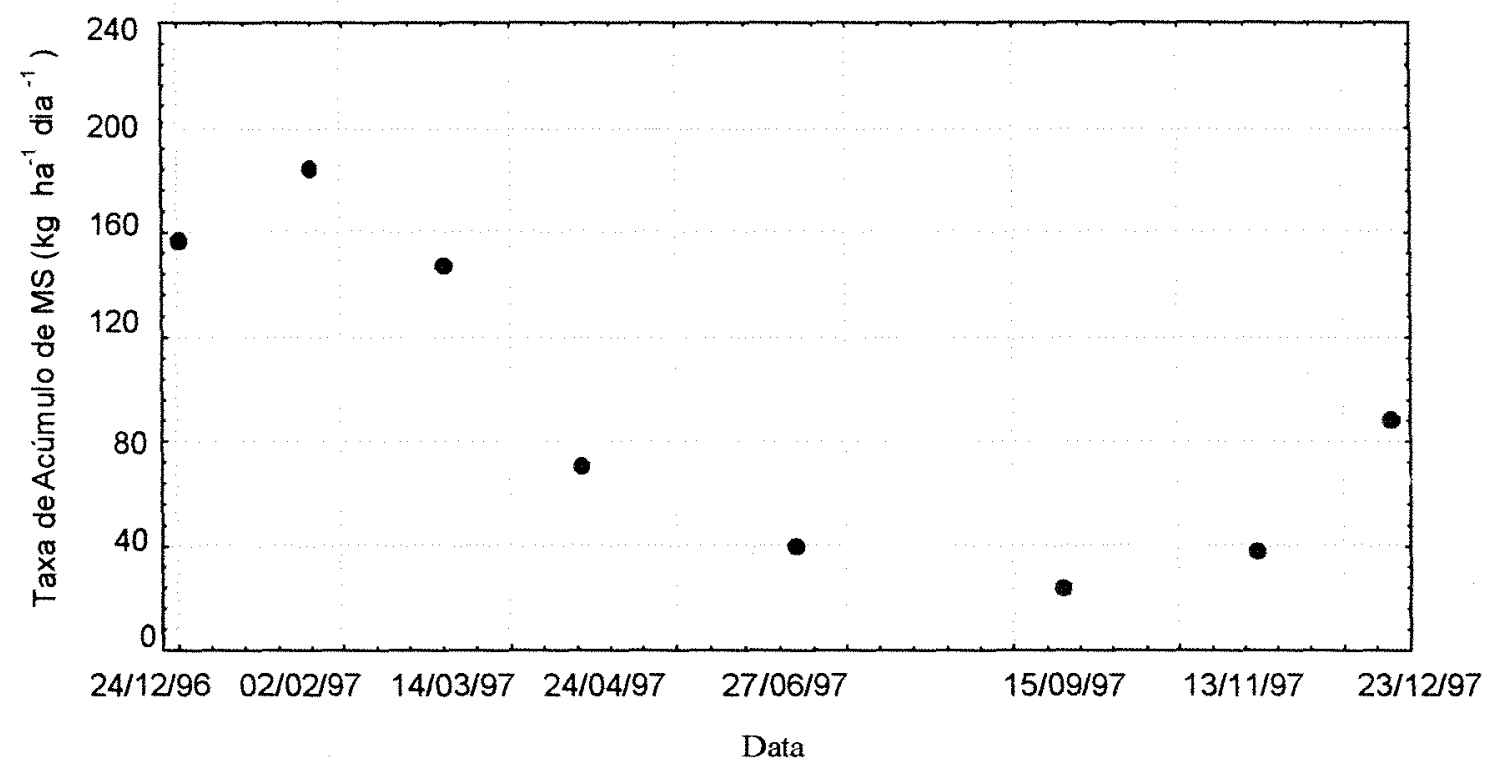

Figura 3. Taxa de acúmulo da matéria seca $\left(\mathrm{kg} \mathrm{MS} \mathrm{ha}^{-1} \mathrm{dia}^{-1}\right)$ do capim Tanzânia 1 durante o período experimental de 24/12/96 à 23/12/97.

Teixeira (1998) trabalhando com o capim Tobiatã e utilizando adubações de $430 \mathrm{~kg} \mathrm{~N} \mathrm{ha}{ }^{-1}$ ano $^{-1}$, com período de descanso e ocupação de 33 e 1 dia, respectivamente, obteve taxa de acúmulo médio no verão de $256 \mathrm{~kg} \mathrm{MS} \mathrm{ha} \mathrm{kia}^{-1}$. Esse autor também observou estacionalidade de produção, com redução na taxa de acúmulo de matéria seca que foi de um máximo de $368 \mathrm{~kg} \mathrm{MS} \mathrm{ha}^{-1} \mathrm{dia}^{-1}$ para 97 kg MS ha ${ }^{-1} \mathrm{dia}^{-1}$, nos meses de Jan./96 e Maio/96, respectivamente. 


\subsection{Valor nutritivo da forragem}

As médias das variáveis digestibilidade verdadeira "in vitro" da matéria seca (DVIVMS), fibra em detergente neutro (FDN), proteína bruta (PB) durante 0 período experimental assim como seus respectivos desvios padrão e coeficientes de variação podem ser observados na Tabela 2

Tabela 2. Médias de \% de matéria seca, digestibilidade verdadeira "in vitro" da matéria seca (\%), fibra em detergente neutro (\%) e proteína bruta (\%) e seus correspondentes desvios padrão e coeficientes de variação.

\begin{tabular}{|c|c|c|c|}
\hline Variável & Média & $\begin{array}{l}\text { Desvio } \\
\text { Padrio }\end{array}$ & $\mathbf{C V}$ \\
\hline$\%$ Matéria Seca & 24,50 & 3,71 & 15,13 \\
\hline DVIVMS \% & 71,41 & 3,11 & 4,35 \\
\hline FDN \% & 69,38 & 1,22 & 1,76 \\
\hline PB \% & 10,07 & 1,99 & 19,79 \\
\hline
\end{tabular}

A variação na porcentagem de matéria seca ao longo do tempo foi de pequena magnitude, apresentando resultados com maior freqüência entre 22 e $24 \%$, porém, os pastejos de junho e setembro apresentaram valores maiores quando comparados com os demais (Figura 4). Esses valores são decorrentes da menor freqüência de pastejo utilizada no "inverno" e da menor decomposição do material morto ocasionado por fatores ambientais. O teor médio de matéria seca observado no "verão" $(22,32 \%)$ foi superior aos dados de Teixeira (1998), que obteve um teor médio de $19,55 \%$ para o mesmo período quando utilizou o capim Tobiatã pastejado a cada 33 dias. 


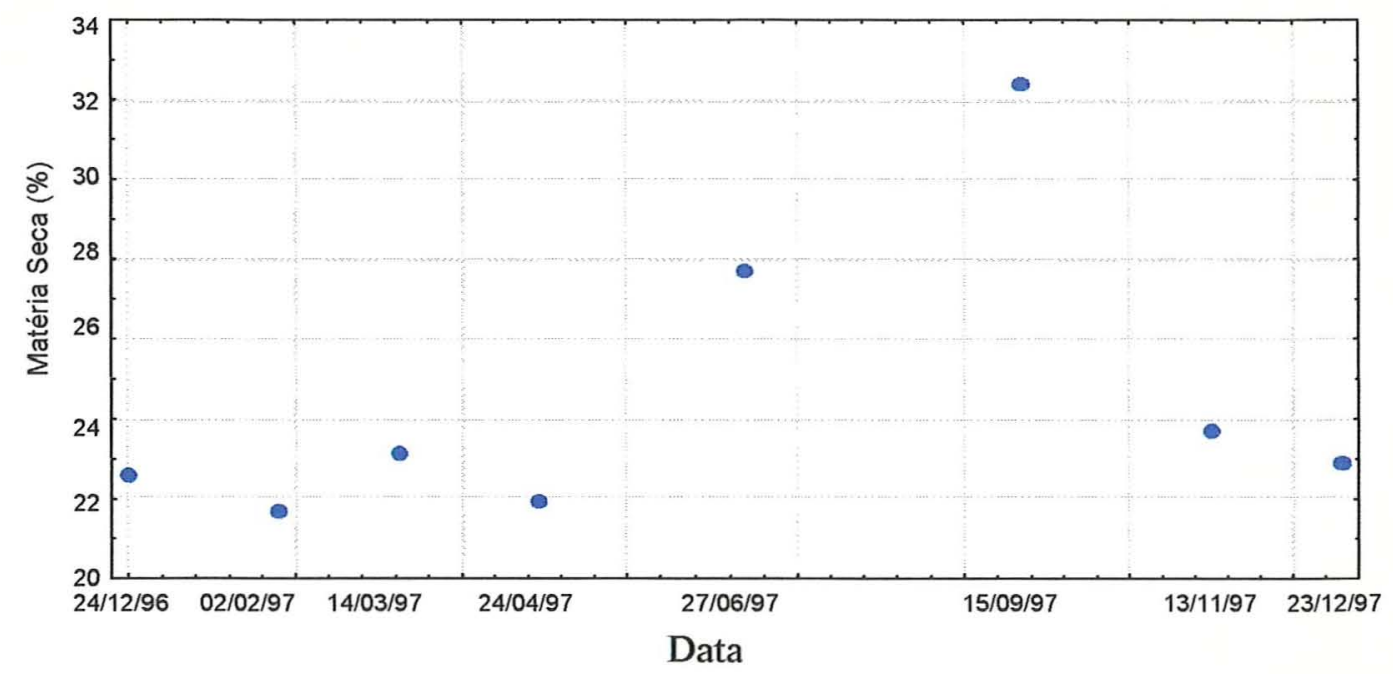

Figura 4. Variação da porcentagem de matéria seca do capim Tanzânia 1 durante o período experimental.

Os teores de PB do capim Tanzânia 1 nos períodos de observação foram respectivamente 10,$90 ; 10,90 ; 12,60 ; 11,90 ; 10,20$; 6,$70 ; 9,0$ e 8,20\% (Figura 5), apresentando uma estacionalidade nessa variável. Nota-se que o teor médio de PB foi de 11,62 e 8,63 para o "verão" e "inverno", respectivamente. Estes valores estão acima dos 7\% sugeridos por Wilson \& Minson (1980) como nível mínimo para a manutenção da atividade ruminal.

Balsalobre (1996) relatou teor de PB médio de 7,8\% no pastejo simulado do capim elefante manejado em sistema rotacionado. Barbosa \& Euclides (1997) observaram médias de 11,6; 11,1; e $12,3 \%$ de $\mathrm{PB}$ para as folhas de cultivares de Panicum maximum: Mombaça, T21 e Tanzânia 1, respectivamente, no período do "verão". Sarmento et al. (1997), estudando o capim Tobiatã pastejado a cada 
24 dias, obtiveram teores médios de $10,98 \%$ de PB. Corrêa et al. (1998 b) trabalhando com valor nutritivo de forragem obtiveram para o capim Tanzânia 1 cortado com uma freqüência de 35 dias e uma adubação equivalente ao presente experimento uma média de $13 \%$ de PB no período de "verão". Oliveira (1980) obteve para a $B$. decumbens um teor de $\mathrm{PB}$ de 7,90,4,80 e 3,50\% em cortes efetuados aos 21, 42 e 63 dias de idade, respectivamente. Teixeira (1998) trabalhando com capim Tobiatã cortado a intervalos de 33 dias obteve teor médio de $14,46 \%$ de $\mathrm{PB}$ no verão para o pastejo simulado.

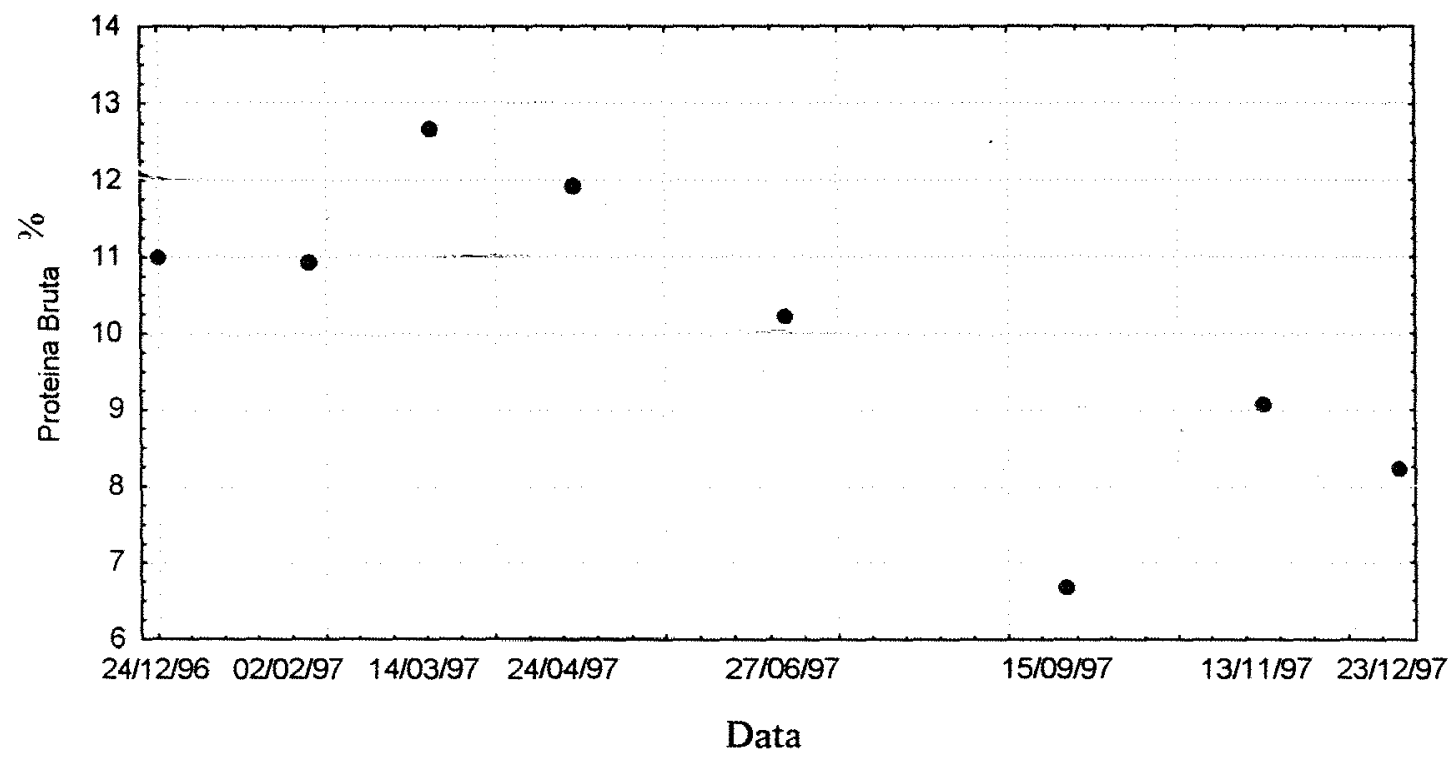

Figura 5. Variação nos teores de proteína bruta $(\%)$ do capim Tanzânia 1 durante o periodo experimental.

Os valores observados no Figura 5 mostram que os teores de PB foram superiores no "verão" quando comparados ao "inverno". Esse fato deve-se, provavelmente, ao maior período de descanso observado no "inverno"(72 dias) em relação ao "verão"(36 dias). Além desse 
aspecto as pastagens não foram adubadas durante o "inverno" e as condições climáticas (Figura 1) não favoreceram a atividade microbiana responsável pela decomposição da matéria orgânica. Zimmer et al. (1988) relataram o aumento da relação haste:folha no período da "seca". Em folhas jovens a concentração de $\mathrm{N}$ é mais elevada (Corsi \& Nascimento Júnior, 1994). Minson (1992) apontou as folhas como sendo a fração da forrageira mais rica em PB e menos fibrosa, sendo, portanto, mais digestível. Dessa maneira, fica claro que para um melhor desempenho animal a pastagem deve ser manejada de forma tal que tenha uma boa rebrota, produza bom volume de forragem, sendo esta constituida principalmente de folhas (Zimmer et al., 1988).

Na Figura 6 observa-se que os teores de FDN obtidos durante o período experimental apresentaram um aumento ao longo do ano e uma pequena amplitude de 3,07\%. Os teores médios de FDN foram 68,97 e $69,40 \%$ para o "verão" e "inverno", devido ao efeito da maturidade da forragem ocasionada principalmente pela menor freqüência de pastejo observada durante o inverno.

Nota-se que os teores obtidos nos dias de pastejo 24/12/96, 02/02/97 e 27/06/97 foram inferiores, devido a uma quantidade superior de folhas verdes em relação a folhas senescentes e mortas, fato esse ocasionado pelo corte de uniformização realizado. Alem desse fato, pequena variação na altura do resíduo em relação a altura de corte pode ter ocasionado a variação observada no valor da FDN. 


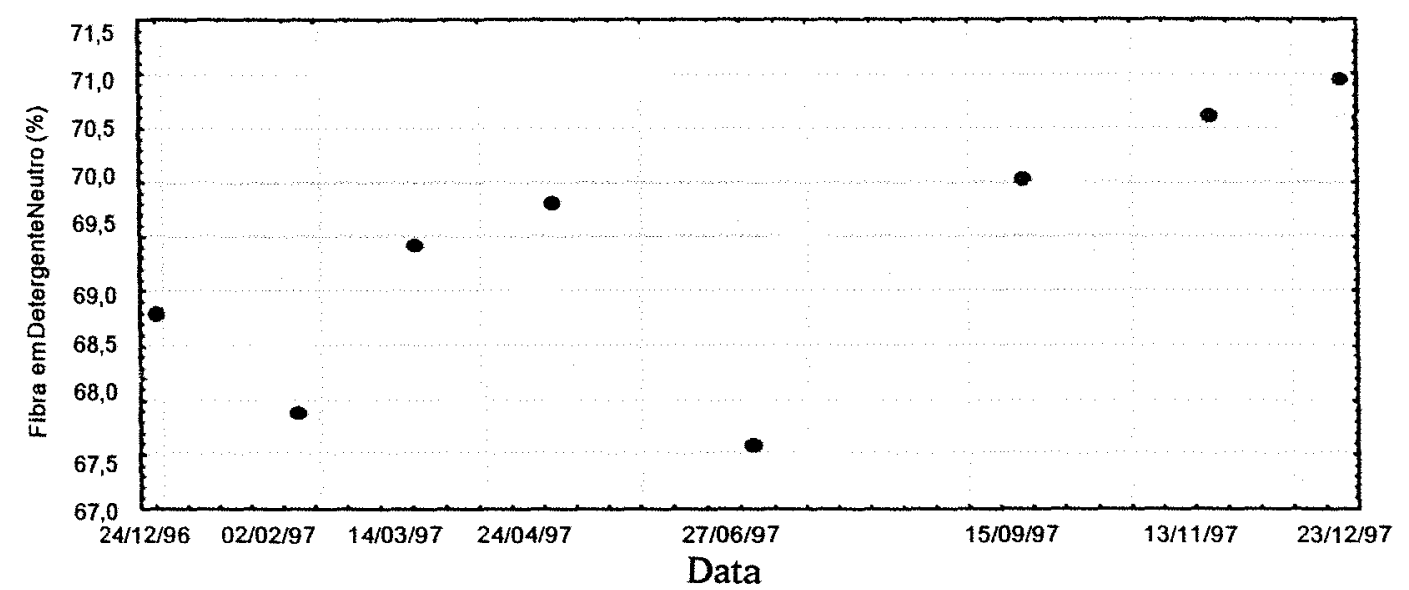

Figura 6. Variação nos teores de fibra em detergente neutro (\%) do capim Tanzânia 1 durante o período experimental.

Andrade (1987) observou em capim Tobiatã efeito significativo da maturidade sobre o teor de FDN da forrageira, sendo que dos 28 aos 56 dias de crescimento o teor desse componente na planta aumentou de $68,45 \%$ para $77,85 \%$. Corrêa et al.(1998b) trabalhando com Tanzânia 1 constatou que a idade de corte não afetou significativamente o teor de FDN, obtendo um valor médio para o "verão" de 74,5\%. Para um período de crescimento de 35 dias no início do período do verão Barbosa \& Euclides (1997) observaram para o capim Tanzânia 1 teores de $72,9 \%$ e $80,0 \%$ de FDN para as folhas e hastes, respectivamente. Teixeira (1998) observou teores médios de FDN, no "verão", de $61,63 \%, 65,75 \%$ e $70,31 \%$ para o pastejo simulado, folhas e hastes, respectivamente, para o capim Tobiatã, utilizando uma freqüência de pastejo de 33 dias.

O valor médio da digestibilidade verdadeira "in vitro" da matéria seca (DVIVMS) do capim Tanzânia 1 neste experimento foi de $71,41 \%$ (Tabela2). A DVIVMS parece variar pouco ao longo do 
ano (entre 70 e $74 \%$ ), porém, observou-se um valor máximo de $76,07 \%$ e um mínimo de $65,5 \%$ nos pastejos realizados em 14/03/97 e 15/09/97, respectivamente (Figura 7). Este maior valor constatado foi atribuído à intensa produção de folhas no período (Tabela 7) proporcionando, dessa maneira, um melhor valor nutritivo da forragem. De fato, na Figura 5 pode ser observado o alto teor de PB nesse mesmo período. O menor valor de DVIVMS obtido durante ò “inverno", na data de 15/09/97 foi devido a menor freqüência de pastejo (Figura 7).

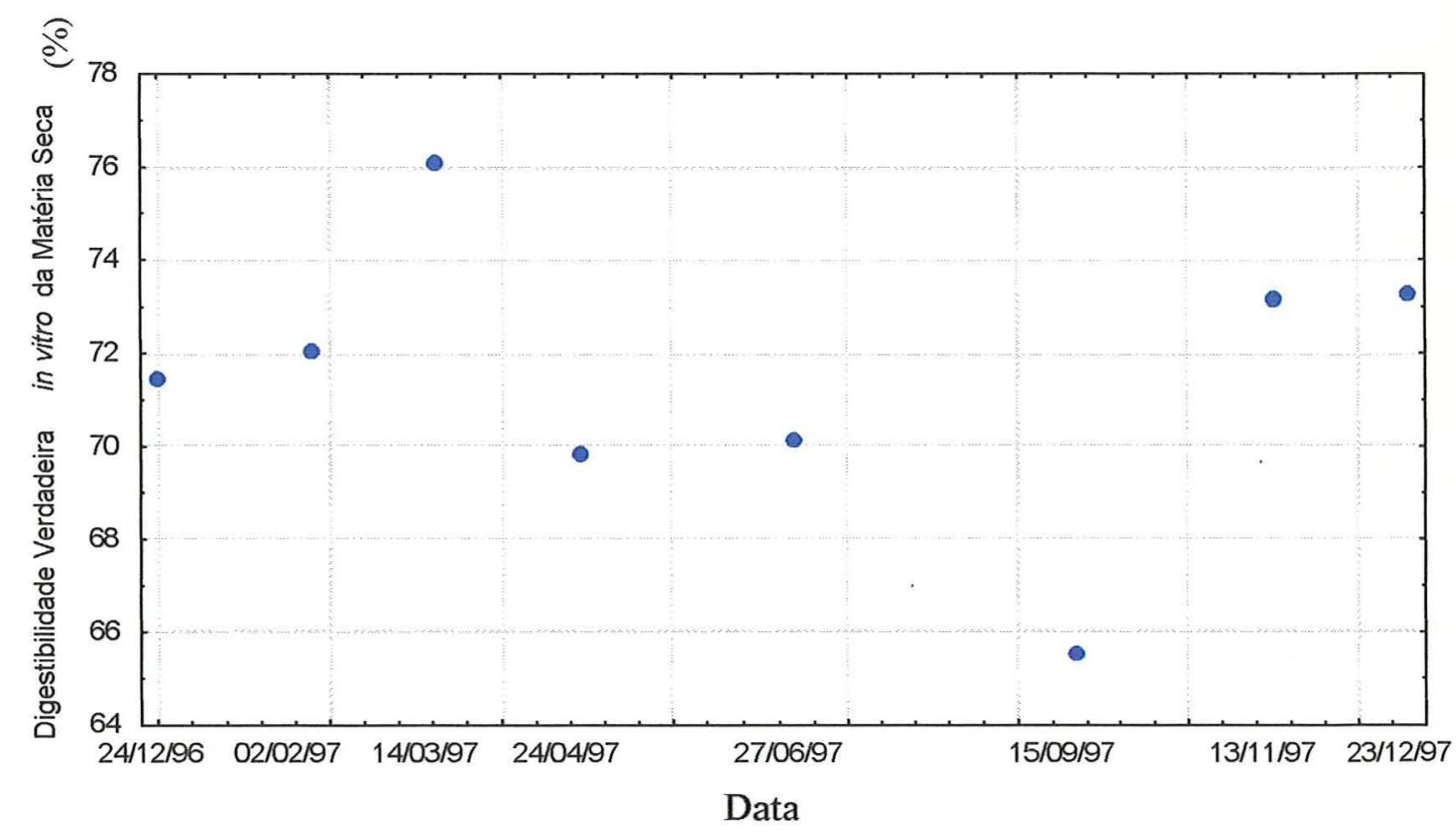

Figura 7. Variação na digestibilidade "in vitro" verdadeira da matéria seca (\%) do capim Tanzânia 1 durante o período experimental.

O decréscimo na digestibilidade com o aumento da idade de corte também foi observado em condições de pastejo por Mislevy et al. (1988); Adjei et al. (1989) e Pedreira (1995). Costa \& Oliveira (1997) observaram em capim Tobiatã valores de 64,3; 62,7 e 52,2\% de DIVMS quando a forragem foi cortada nas idades de 28, 42 e 56 
dias de crescimento. Minson (1971) relatou que as taxas de decréscimo na digestibilidade durante o crescimento de gramíneas do gênero Panicum são maiores que às das outras gramíneas tropicais, da ordem de 0,1 unidade percentual por dia. Teixeira (1998) trabalhando com capim Tobiatã pastejado a cada 33 dias obteve um teor médio de DVIVMS de $74,2 \%$ para as folhas no período do "verão".

\subsection{Perdas de forragem pelo pastejo}

As médias da variável perdas de forragem pelo pastejo (kg MS ha $^{-1}$ ) durante o período experimental e seus respectivos desvios padrão e coeficientes de variação (CV) podem ser observadas na Tabela 3 .

Tabela 3. Médias de perdas de forragem pelo pastejo e seus desvios padrão e coeficientes de variação.

\begin{tabular}{|c|c|c|c|}
\hline Pastejo & Média (kg MS ha') & $\begin{array}{c}\text { Desvio } \\
\text { Padrão }\end{array}$ & C V \\
\hline Pastejo1 $(24 / 12 / 96)$ & 1390 & 6,56 & 0,47 \\
\hline Pastejo2 (02/02/97) & 1900 & 6,45 & 0,34 \\
\hline Pastejo3 (14/03/97) & 1810 & 16,18 & 0,89 \\
\hline Pastejof (24/04/97) & 560 & 6,81 & 1,20 \\
\hline Pastejo5 (27/06/97) & 330 & 9.83 & 2,94 \\
\hline Pastejo6 (15/09/97) & 760 & 8,02 & 1,05 \\
\hline Pastejo7 (13/11/97) & 790 & 8.60 & 1,09 \\
\hline Pastejo8 (23/12/97) & 830 & 3,79 & 0.46 \\
\hline Anual & 1050 & 556.05 & 53.03 \\
\hline
\end{tabular}


As perdas pelo pastejo apresentaram uma evidente estacionalidade, apresentando valores superiores nos pastejos realizados no início do experimento (Figura 8). A média obtida durante o verão e inverno foi de 1300 e $629 \mathrm{~kg} \mathrm{MS} \mathrm{ha}^{-1}$ após cada pastejo, respectivamente. A estacionalidade apresentada na Figura 8 é semelhante à observada para produção de matéria seca (Figura 2). Dessa forma, as perdas foram mais elevadas nos períodos onde a disponibilidade de MS e a altura da planta tenderam a ser maiores. Hillesheim (1987) observou que para o capim-elefante as perdas de pastejo foram menores quanto maior a porcentagem de folhas na planta, quanto mais baixa a altura de seu meristema apical e quando as disponibilidades de MS total animal ${ }^{-1}(\% \mathrm{PV})$ foram menores. Esse autor encontrou um valor médio de perda de forragem após o pastejo de $1124 \mathrm{~kg} \mathrm{MS} \mathrm{ha}^{-1}$ durante o período das águas. Estudando o mesmo capim, Balsalobre (1996) observou que foram perdidos em média $1973 \mathrm{~kg} \mathrm{MS} \mathrm{ha-1}$ após o pastejo. Teixeira (1998) obteve $1179 \mathrm{~kg}$ MS $\mathrm{ha}^{-1}$ de perdas pelo pastejo utilizando capim Tobiatã sob pastejo no período das águas o que correspondem a $9,4 \%$ da produção de matéria seca. 


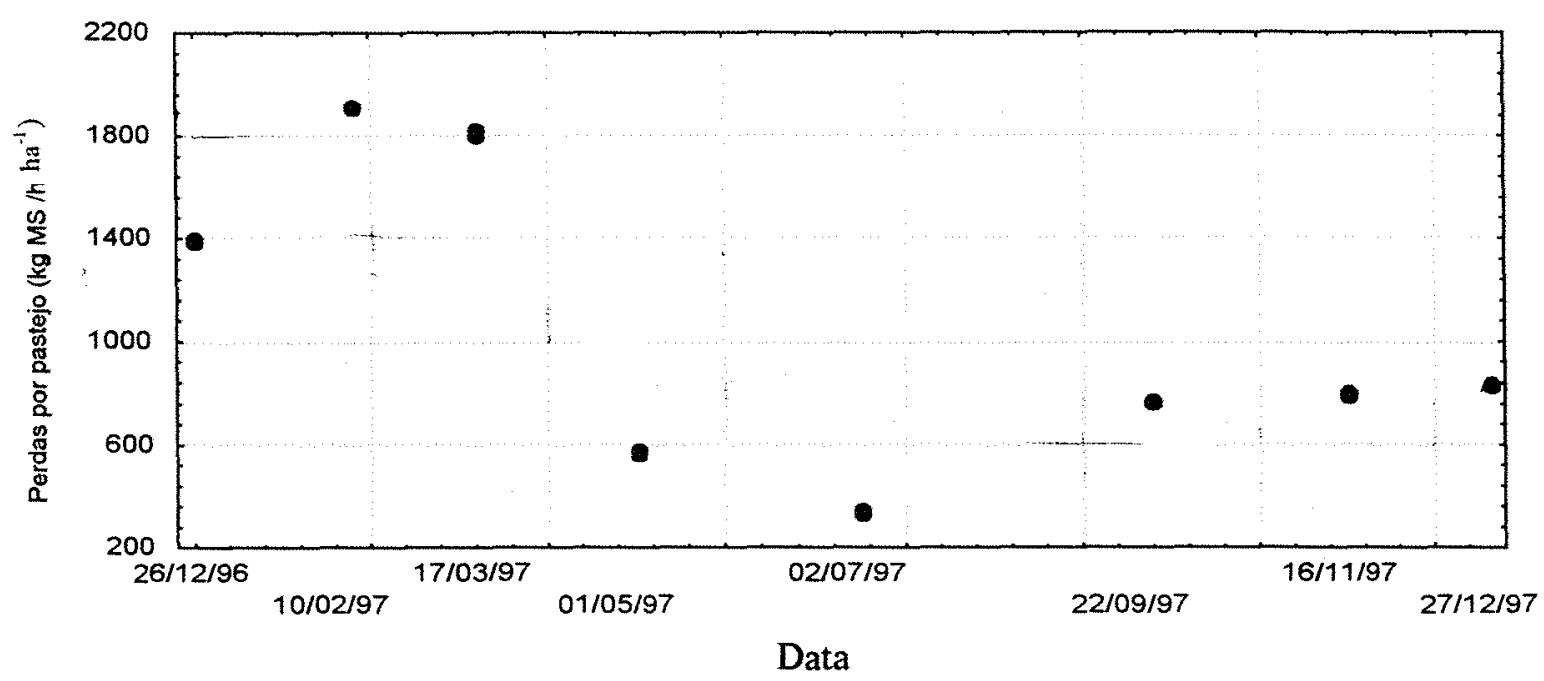

Figura 8. Perdas de forragem pelo pastejo $\left(\mathrm{kg} \mathrm{MS} \mathrm{ha}^{-1}\right)$ do capim Tanzânia 1 durante 0 período experimental.

Os valores de perdas de forragem através do pastejo no presente trabalho corresponderam a $24 \% ; 28 \% ; 33 \% ; 21 \% ; 14 \%$; $45 \%$; $39 \%$ e $25 \%$ da produção de matéria seca para as seguintes datas de pastejo, respectivamente $26 / 12 / 96 ; 10 / 02 / 97 ; 17 / 03 / 97 ; 01 / 05 / 97$; 02/07/97; 22/09/97; 16/11/97 e 27/12/97. As perdas em porcentagem da produção de matéria seca observadas durante os pastejos de (Set.97) e (Nov.97) foram elevadas devido ao grande acúmulo de material morto, principalmente do resíduo que não foi decomposto pela falta de chuvas e derrubado pela ação do pastejo. Possivelmente as perdas decorrentes do pastejo em capim Tanzânia 1 neste experimento poderiam ter sido minimizadas caso a planta tivesse sido manejada numa altura menor de resíduo de forma a assegurar uma maior proporção de folhas. A exploração da planta forrageira através desse manejo exigiria, no entanto, além de menores alturas de resíduo, maior nível de fertilidade do solo. 


\subsection{Dinâmica do perfilhamento}

As médias da densidade populacional de perfilhos (perfilhos $\mathrm{m}^{-2}$ ) durante o período experimental e seus respectivos desvios padrão e coeficientes de variação (CV) podem ser observadas na Tabela 4 .

Tabela 4. Médias de densidade populacional de perfilhos $\mathrm{m}^{-2}$ seus desvios padrão e coeficientes de variação.

\begin{tabular}{|c|c|c|c|}
\hline Pastejo & $\begin{array}{c}\text { Média (perfilhos } \\
\mathrm{m}^{-2} \text { ) } \\
\end{array}$ & $\begin{array}{c}\text { Desvio } \\
\text { Padrão } \\
\end{array}$ & $\mathrm{CV}$ \\
\hline Pastejo1 $(24 / 12 / 96)$ & 445 & 13,36 & 3,00 \\
\hline Pastejo2 (02/02/97) & 459 & 3,57 & 0,78 \\
\hline Pastejo3 (14/03/97) & 415 & 9,02 & 2.17 \\
\hline Pastejo4 (24/04/97) & 547 & 15,81 & 2,89 \\
\hline Pastejo5 (27/06/97) & 657 & 33,69 & 5,12 \\
\hline Pastejo6 (15/09/97) & 586 & 16,95 & 2,89 \\
\hline Pastejo7 (13/11/97) & 595 & 7,84 & 1.32 \\
\hline Pastejo8 (23/12/97) & 609 & 13.19 & 2.16 \\
\hline Média Anual & 539 & 85.79 & 15.90 \\
\hline
\end{tabular}

$\mathrm{Na}$ avaliação de densidade populacional de perfilhos obteve-se valores relativamente menores nos pastejos iniciais (pastejos 1 ao 3), oscilando entre 415 a 429 perfilhos $\mathrm{m}^{-2}$ no periodo experimental. Este fato ocorreu devido ao corte de uniformização com roçadeira em outubro de 1996 provocando a morte de grande número de perfilhos. A partir do pastejo 4 a população de perfilhos apresentou um aumento, mantendo-se relativamente constante e oscilando entre 574 a 657 perfilhos $\mathrm{m}^{-2}$ (Figura 9). 
Gomide et al. (1997) trabalhando com B. decumbens obteve uma média de densidade de perfilhos em diferentes alturas de corte de 3380 perfilhos $\mathrm{m}^{-2}$.

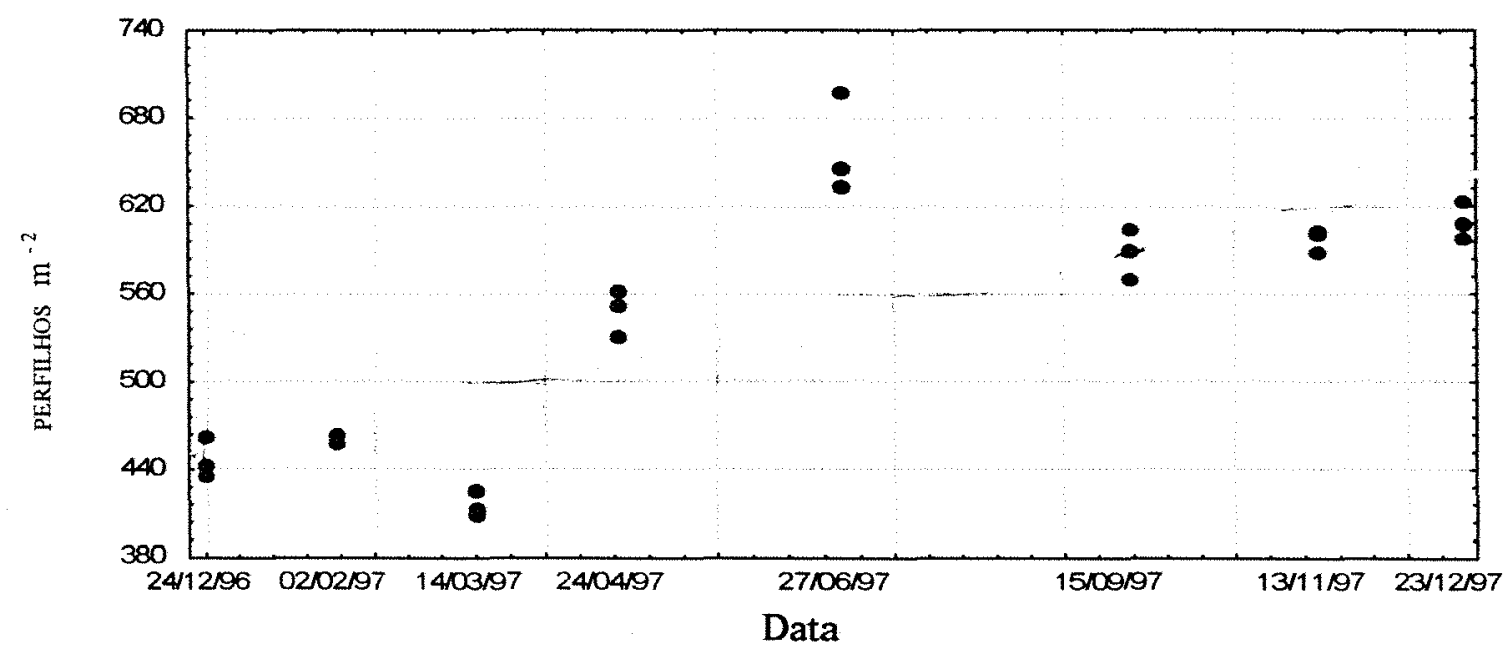

Figura 9. Densidade populacional de perfilhos (perfilhos $\mathrm{m}^{-2}$ ) do capim Tanzânia 1 durante o período experimental.

Herling (1998b) trabalhando com perfilhamento do capim Mombaça sob pastejo obteve uma média de 604 perfilhos $\mathrm{m}^{-2}$. Santos (1997) trabalhando com capim Tanzânia 1 obteve durante o ano uma oscilação entre 136 a 359 perfilhos $\mathrm{m}^{-2}$. Os menores valores foram obtidos no mês de abril/maio, e justificados em virtude do florescimento.

No presente experimento o período de abril/maio não apresentou uma densidade de perfilhos muito inferior em relação aos outros períodos, como foi observado por Santos (1997), pois o 
florescimento foi muito pequeno em decorrência, provavelmente a uniformidade de pastejo e menor produtividade de matéria seca durante o período reprodutivo dessa espécie forrageira que se estabelece entre os meses de Março/Abril (Figura 3 ).

As médias das variáveis aparecimento, mortalidade e sobrevivência de perfilhos durante o período experimental e seus respectivos desvios padrão e coeficientes de variação podem ser observadas na Tabela 5 .

A taxa de aparecimento de perfilhos apresentou a maior média no período $1(51,70 \%)$ e a menor no período $3(20,93 \%)$. Da mesma maneira, a maior média da taxa de mortalidade também ocorreu no período $1(48,99 \%)$ e a menor também no período $3(16,91 \%)$. Em consonância com os resultados para mortalidade de perfilhos, observou-se que a maior média de sobrevivência ocorreu no período $3(83,09 \%)$, e a menor média $(51,01 \%)$ no período 1 (Tabela 5 ). 
Tabela 5. Taxas de aparecimento, mortalidade e sobrevivência de perfilhos em porcentagem e seus correspondentes desvios padrão e coeficientes de variação.

\begin{tabular}{|c|c|c|c|}
\hline & Média (\%) & Desvio Padrão & $\mathbf{C V}$ \\
\hline \multicolumn{4}{|c|}{ Período 1 (27/12/96 à 02/02/97) } \\
\hline$\%$ aparecimento & 51,70 & 24,51 & 47,42 \\
\hline$\%$ mortalidade & 48,99 & 4,46 & 9,11 \\
\hline \%sobrevivência & 51,01 & 4,46 & 8,75 \\
\hline \multicolumn{4}{|c|}{ Período $2(06 / 02 / 97$ à 14/03/97) } \\
\hline$\%$ aparecimento & 33,09 & 4,55 & 13,76 \\
\hline$\%$ mortalidade & 29,25 & 11,34 & 38,76 \\
\hline \%sobrevivência & 70,75 & 11,34 & 16,03 \\
\hline \multicolumn{4}{|c|}{ Período 3 (18/03/97 à 24/04/97) } \\
\hline \% aparecimento & 20,93 & 7,65 & 36,55 \\
\hline \%mortalidade & 16,91 & 5,12 & 30,29 \\
\hline \%sobrevivência & 83,09 & 5,12 & 6,17 \\
\hline \multicolumn{4}{|c|}{ Período 4 (27/04/97 à 27/06/97) } \\
\hline$\%$ aparecimento & 27,40 & 4,33 & 15,80 \\
\hline$\%$ mortalidade & 20,13 & 6,95 & 34,55 \\
\hline \%sobrevivência & 79,87 & 6,95 & 8,71 \\
\hline \multicolumn{4}{|c|}{ Período $5(03 / 07 / 97$ à 15/09/97) } \\
\hline$\%$ aparecimento & 27,83 & 10,19 & 36,61 \\
\hline$\%$ mortalidade & 23,12 & 9,54 & 41,26 \\
\hline \%sobrevivência & 76,88 & 9,54 & 12,41 \\
\hline \multicolumn{4}{|c|}{ Período 6 (21/09/97 à 13/11/97) } \\
\hline$\%$ aparecimento & 42,48 & 11,83 & 27,84 \\
\hline \%mortalidade & 21,74 & 1,83 & 8,42 \\
\hline \%sobrevivência & 78,26 & 1,83 & 2,34 \\
\hline \multicolumn{4}{|c|}{ Período 7 (19/11/97 à 23/12/97) } \\
\hline$\%$ aparecimento & 44,40 & 7,08 & 15,94 \\
\hline$\%$ mortalidade & 28,84 & 7,92 & 27,46 \\
\hline \%sobrevivência & 71,16 & 7,92 & 11,13 \\
\hline \multicolumn{4}{|c|}{ Média Anual } \\
\hline$\%$ aparecimento & 35,40 & 14,46 & 40,86 \\
\hline \% mortalidade & 27,00 & 11,86 & 43,91 \\
\hline \%sobrevivência & 73,00 & 11,86 & 16,24 \\
\hline
\end{tabular}

Esta variável avaliada de dezembro/96 a dezembro/97, apresentou um comportamento estacional devido aos fatores de crescimento (água, luz, fotoperíodo, temperatura) atingindo a taxa máxima no "verão" e mínima no "inverno" (Figura 10). 


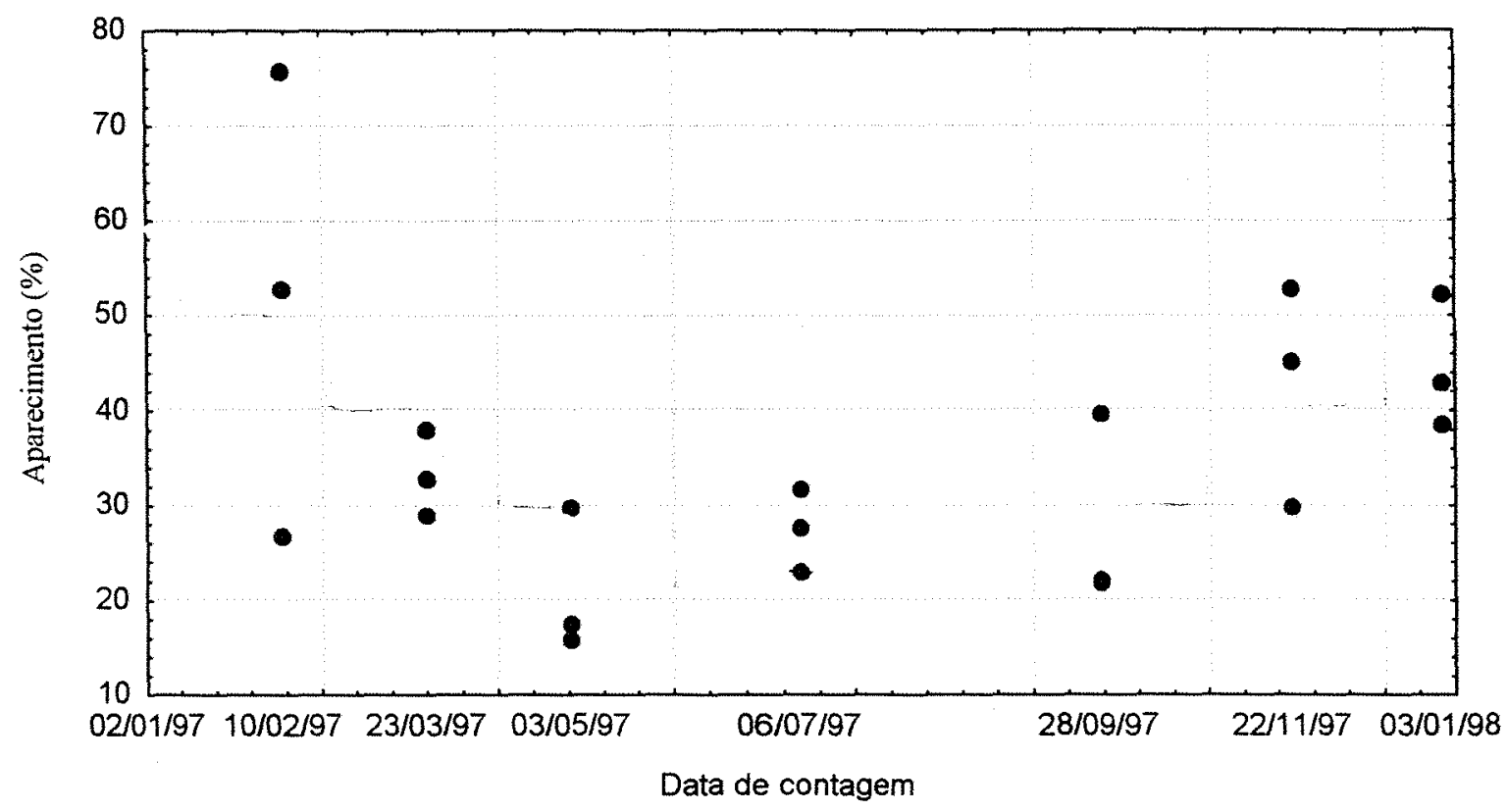

Figura 10. Taxa de aparecimento de perfilhos (\%) no capim Tanzânia 1 durante o período experimental

Na Figura 11 estão apresentadas as taxas de mortalidade e sobrevivência de perfilhos no período experimental. Esta variáveis também apresentaram uma evidente sazonalidade devido aos fatores de crescimento.

A taxa de mortalidade apresentou valores mínimos no período entre $03 / 05 / 07$ à $28 / 09 / 97$ e, consequentemente, taxas máximas para a sobrevivência de perfilhos no mesmo período (Figura 11). 


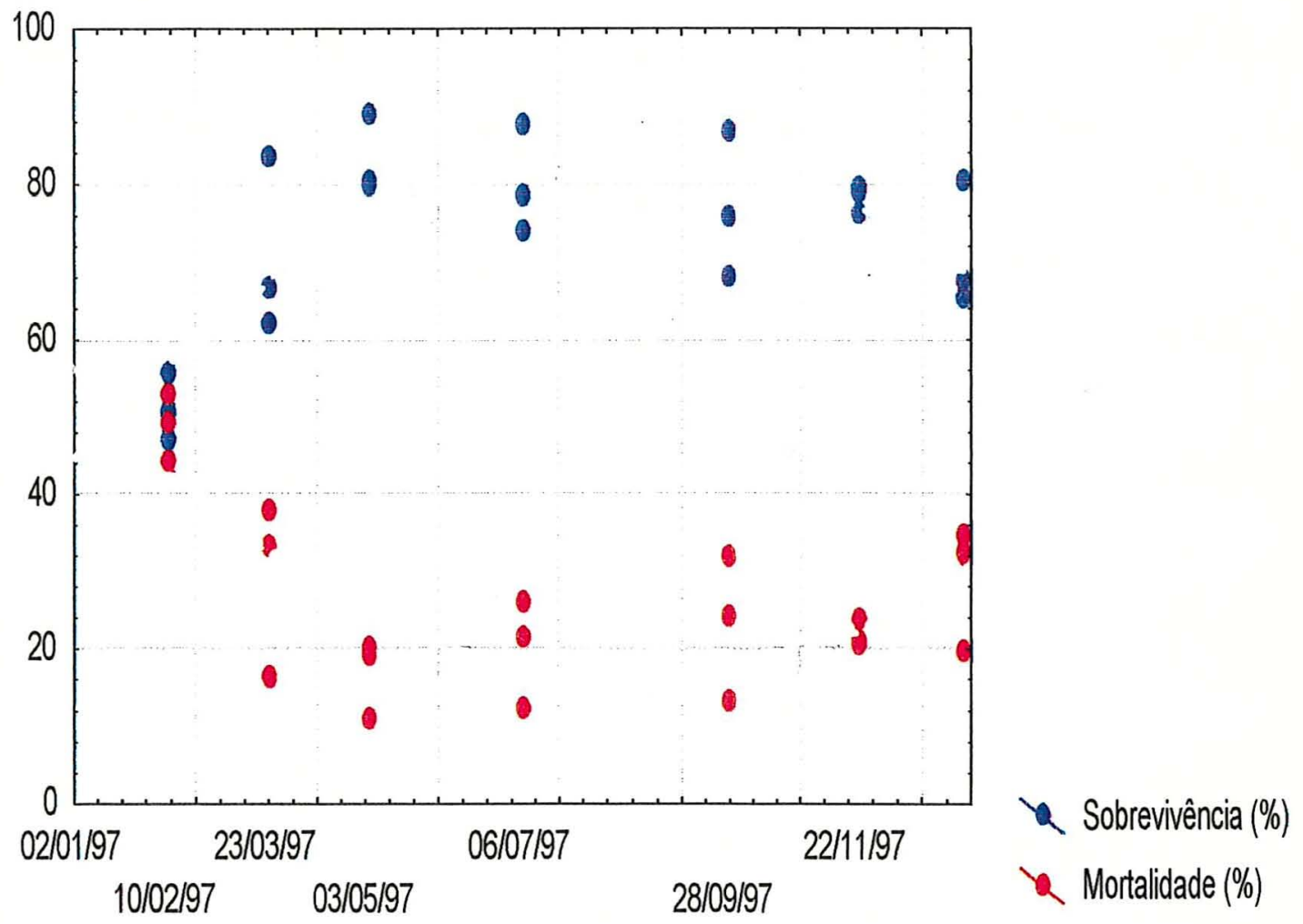

Data de Contagem

Figura 11. Taxas de sobrevivência e mortalidade (\%) de perfilhos do capim Tanzânia 1 durante o período experimental.

A Figura 12 apresenta o comportamento das diferentes gerações de perfilhos, evidenciando uma grande longevidade. Observou-se declínios, aparentemente constantes, nas diferentes gerações de perfilhos, com valores mais acentuados durante o "verão" em relação ao "inverno", pois, conforme se verifica na Figura 11 ocorreu uma maior taxa de mortalidade durante o período de "verão". 
A população de perfilhos manteve-se relativamente constante, com um pequeno aumento no decorrer do experimento (Figura 12), como foi observado na Figura 9.

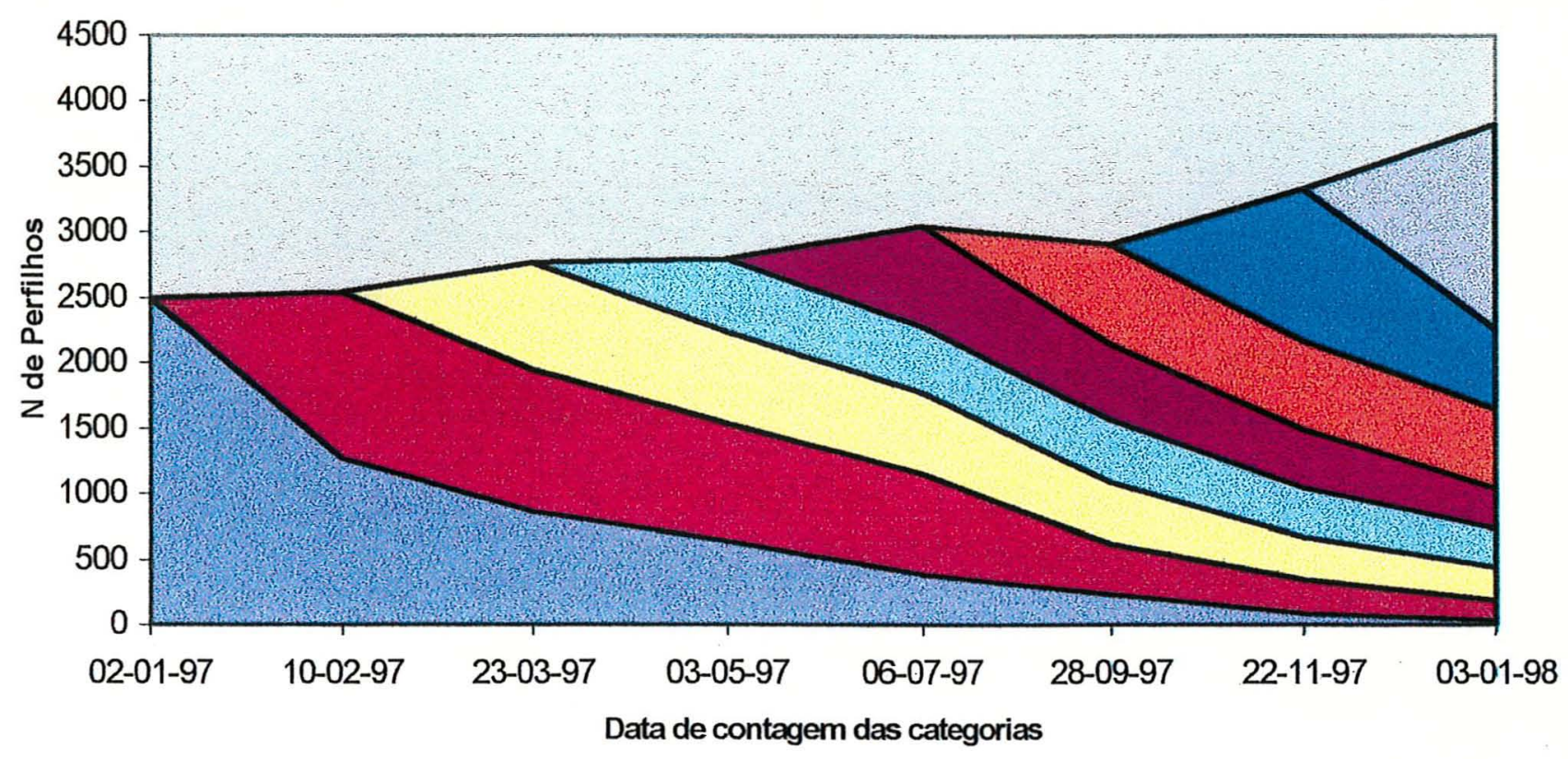

Figura 12. Dinâmica do perfilhamento (Número de Perfilhos) do capim Tanzânia 1 durante o período experimental.

Barbosa et al. (1996) observou que a dinâmica do perfilhamento é variável entre as estações de crescimento. Carnevali \& da Silva (1998) trabalhando com Cynodon dactylon e selecionando inicialmente plantas individuais para avaliar a dinâmica populacional de perfilhos, obtiveram uma diminuição na população. Após alterações da metodologia, delimitando-se áreas como unidade de avaliação, concluíram que foi possível acompanhar o aparecimento e a morte dos perfilhos de maneira mais efetiva, assim como o local de 
origem, visto que houve um número considerável de perfilhos provenientes da sub-superfície do solo (10 a $30 \%$ dos perfilhos que nasceram) que não haviam sido contabilizados com o procedimento anterior.

Os dados apresentados neste trabalho permitem avaliar a dinâmica do perfilhamento do capim Tanzânia 1, e sugerem a necessidade de maior número de trabalhos nesta área para definir as diferentes categorias de perfilhos responsáveis pela produção e qualidade da matéria seca dessa planta forrageira. Os resultados apontam para o fato de que a população de perfilhos da pastagem esta ajustando-se a condições de manejo ao longo do ano, indicando que, pode-se aumentar o perfilhamento através de pastejos mais pesados associado a melhor fertilidade do solo. A resposta do capim Tanzânia 1 permitindo aumento no perfilhamento durante o período do "inverno" mostra a capacidade dessa espécie forrageira para produzir alimento de boa qualidade naquela época do ano, diferindo do capim Colonião que tem capacidade reduzida de perfilhamento no "inverno".

\subsection{Fluxo de tecidos}

A análise descritiva do fluxo de tecidos foi realizada através da interpretação de gráficos do tipo box-plot (Figuras 13, 14, 15 e 16) que são úteis para visualizar o comportamento da variável estudada, principalmente quanto a sua variabilidade. Essencialmente, estes são formados por uma caixa que representa o " $50 \%$ " central das 
observações e uma linha que abrange desde os valores mínimo e máximo observados. Quando a média aritmética é aproximadamente zero, o coeficiente de variação não é uma ferramenta útil para medir a variabilidade amostral.

As médias de crescimento de hastes durante o período experimental e seus respectivos desvios padrão e coeficientes de variação podem ser observados na Tabela 6.

Tabela 6. Médias de crescimento de haste $\left(\mathrm{cm} \mathrm{haste}{ }^{-1} \mathrm{dia}^{-1} \mathrm{e} \mathrm{mg}\right.$ haste $^{-1} \operatorname{dia}^{-1}$ ) e seus desvios padrão e coeficientes de variação.

\begin{tabular}{|c|c|c|c|}
\hline Periodo & Média & $\mathrm{CV}$ & $\begin{array}{r}\text { Desvio } \\
\text { Padrão }\end{array}$ \\
\hline \multicolumn{4}{|c|}{ em cm haste ${ }^{-1}$ dia $^{-1}$} \\
\hline 1 & 0,167 & 110,14 & 0,184 \\
\hline 2 & 0,068 & 144,51 & 0,098 \\
\hline 3 & 0,009 & 317,38 & 0,028 \\
\hline 4 & 0,036 & 236,09 & 0,086 \\
\hline 5 & 0,009 & 252,93 & 0,024 \\
\hline 6 & 0,000 & - & 0,000 \\
\hline 7 & 0,001 & 543,06 & 0,001 \\
\hline 8 & 0,138 & 131.95 & 0,182 \\
\hline \multicolumn{4}{|c|}{ em mg haste ${ }^{-1}$ dia $^{-1}$} \\
\hline 1 & 2,44 & 119,57 & $\overline{2,92}$ \\
\hline 2 & 1,48 & 147,13 & 2,18 \\
\hline 3 & 0,21 & 321,99 & 0,67 \\
\hline 4 & 0,59 & 250,76 & 1,48 \\
\hline 5 & 0,21 & 235,14 & 0,50 \\
\hline 6 & 0,00 & - & 0,00 \\
\hline 7 & 0,01 & 545,60 & 0,03 \\
\hline 8 & 2,42 & 128.40 & 3.11 \\
\hline
\end{tabular}

Esta variável apresentou em todos os períodos coeficientes de variação com valores muito alto, pois foram poucas as hastes que apresentaram crescimento no período experimental, diminuindo o 
espaço amostral, o que contribuiu para o aumento na variabilidade dos dados. Merece ser salientado que, independente da época do ano, é provável encontrar hastes cujo crescimento seja praticamente nulo (Figura 13) em decorrência da morfologia do capim Tanzânia 1 que é caracterizado como planta de ciclo tardio e, em determinadas épocas, a formação de haste é representativa quando há elevação do meristema apical antecedendo a formação de inflorescência.

o crescimento de hastes apresentou uma marcada estacionalidade, como pode ser observado na Figura 13. Verifica-se que do período 3 ao 7 , a taxa de crescimento foi próxima de zero. Nota-se também que nos períodos 1,2 e 8 as taxas aumentam mas o mesmo ocorre com a variabilidade das médias registradas. Santos (1997) trabalhando com o capim Mombaça e Tanzânia 1 observou uma clara estacionalidade das taxas de alongamento das folhas e hastes, sendo estas taxas maiores nos períodos de temperatura e precipitação mais elevadas.

Os resultados sobre crescimento das hastes sugerem que seria possível manter baixo o nível de resíduo em pastagens de capim Tanzânia 1 se o manejo permitisse o controle do desenvolvimento das hastes no período de Novembro/Dezembro (período 1) e, com menor importância entre Dezembro/Fevereiro (período 2). O controle do desenvolvimento da haste nestes períodos através de pastejos mais pesados resultaria, provavelmente, em menor desenvolvimento de hastes para o restante do período de crescimento. Estudos sobre esses aspectos devem ser conduzidos com o objetivo de melhorar o aproveitamento qualidade da forragem disponível. 

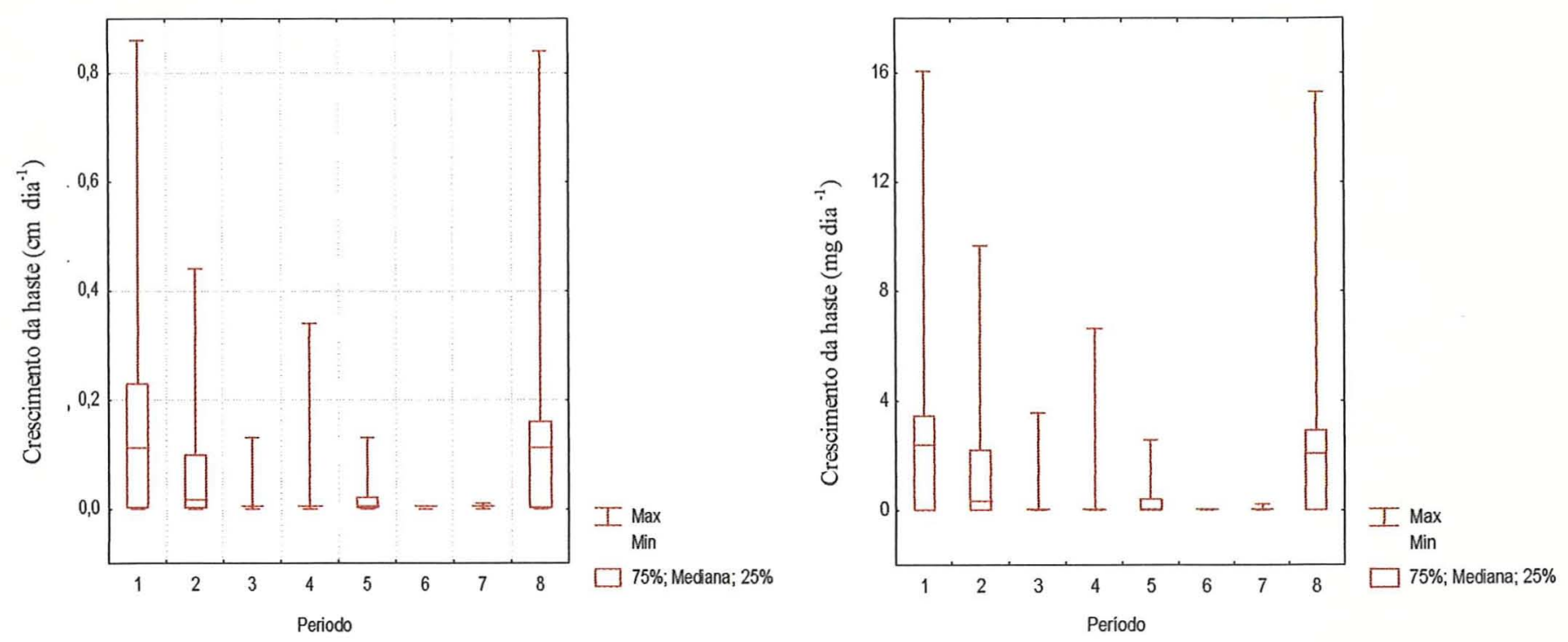

$\mathrm{P} 1=18 / 11 / 96$ a 23/12/96; $\mathrm{P} 2=27 / 12 / 96$ a 01/02/97; $\mathrm{P} 3=05 / 02 / 97$ a 13/03/97; $\mathrm{P} 4=17 / 03 / 97$ a 23/04/97; $\mathrm{P} 5=27 / 04 / 97$ a 26/06/97; $\mathrm{P} 6=03 / 07 / 97$ a $14 / 09 / 97 ; \mathrm{P} 7=21 / 09 / 97$ a $12 / 11 / 97 ; \mathrm{P} 8=19 / 11 / 97$ a $22 / 12 / 97$.

Figura 13: Crescimento da hastes do capim Tanzânia 1 durante o período experimental.

Na Tabela 7 observa-se que as taxas de crescimento de folhas do capim Tanzânia 1 variaram de acordo com o mês de observação, apresentando uma evidente estacionalidade, atingindo um valor máximo no "verão" de 5,13 $\mathrm{cm}$ folha ${ }^{-1} \mathrm{dia}^{-1}$ e mínima no "inverno" de $0,45 \mathrm{~cm}_{\text {folha }}{ }^{-1} \mathrm{dia}^{-1}$. Fatores externos, tais como temperatura (Robson, 1981) e estação do ano (Barbosa et al., 1996) podem influenciar a taxa de crescimento de folhas. A taxa de crescimento é também sensível ao déficit hídrico, pois o aumento em volume das células vegetais é função da pressão de turgor (Horst et al., 1978).

As diferenças observadas na taxa de crescimento de folhas podem ser em grande parte atribuídas às temperaturas médias e a precipitação pluvial observadas durante o experimento (Figura 1), 
pois, nos meses em que a taxa de crescimento foi menor, a precipitação havia ocorrido em níveis baixos. A taxa média de crescimento de folhas para o "verão" $\left(4,11 \mathrm{~cm}^{\text {folha }}{ }^{-1} \mathrm{dia}^{-1}\right)$ sugere o elevado potencial de produção de biomassa vegetal do capim Tanzânia 1 quando comparados com outras gramíneas. Pinto et al. (1994) observaram valores médios de 6,0 e $5,2 \mathrm{~cm}$ folha ${ }^{-1} \mathrm{dia}^{-1}$ para capim Guiné ( $P$. maximum cv. Guiné) e capim Setária (Setharia anceps cv Kazungula), respectivamente. Barbosa et al. (1996) em experimento com $P$. maximum, estimaram as seguintes taxas de crescimento foliar para o capim Tobiatã: 5,$23 ; 7,57$ e $3,21 \mathrm{~cm}^{\text {folha }}{ }^{-1}$ $\operatorname{dia}^{-1}$ para as estações de primavera, verão e inverno, respectivamente. Corsi et al. (1994) em trabalho com gramíneas do gênero Brachiaria, encontraram diferentes taxas de crescimento em função da estação do ano. Foram observadas para a primavera e verão os respectivos valores: 1,23 e $1,19 \mathrm{~cm}^{\text {folha }}{ }^{-1} \mathrm{dia}^{-1}$ (B.brizantha); 0,38 e $0,51 \mathrm{~cm}$ folha ${ }^{-1} \mathrm{dia}^{-1}$ (B.humidicula) e 0,83 e $0,91 \mathrm{~cm}$ folha $^{-1}$ $\operatorname{dia}^{-1}$ (B.decumbens). Teixeira (1998) trabalhando com capim Tobiatã obteve durante o verão uma média de crescimento foliar de $4,05 \mathrm{~cm}$ folha ${ }^{-1} \mathrm{dia}^{-1}$. Gomide et al. (1997) em estudo com B. decumbens obteve média de crescimento de folhas de $21 \mathrm{~mm} \mathrm{dia}^{-1}$ no mês de março. 
Tabela 7. Taxas de crescimento de folhas $\left(\mathrm{cm}\right.$ folha ${ }^{-1} \mathrm{dia}^{-1}$ e $\mathrm{mg}$ folha $^{-1} \mathrm{dia}^{-1}$ ) e seus desvios padrão e coeficientes de variação.

\begin{tabular}{|c|c|c|c|}
\hline Periodo & Média & $\mathrm{CV}$ & $\begin{array}{l}\text { Desvio } \\
\text { Padrão }\end{array}$ \\
\hline \multicolumn{4}{|c|}{ em cm follha dia } \\
\hline 1 & 5,13 & 32,1 & 1,64 \\
\hline 2 & 4,64 & 23,8 & 1,10 \\
\hline 3 & 3,78 & 30,3 & 1,14 \\
\hline 4 & 2,40 & 40,6 & 0,97 \\
\hline 5 & 1,09 & 53,9 & 0,59 \\
\hline 6 & 0,45 & 52,5 & 0,24 \\
\hline 7 & 2,31 & 51,6 & 0,87 \\
\hline 8 & 4,64 & 31,8 & 1,47 \\
\hline \multicolumn{4}{|c|}{ em mg folha $\mathrm{dia}^{-1}$} \\
\hline 1 & 19,46 & 46,02 & 8,95 \\
\hline 2 & 11,12 & 41,68 & 4,63 \\
\hline 3 & 18,04 & 39,81 & 7,18 \\
\hline 4 & 8,54 & 59,02 & 5,04 \\
\hline 5 & 4,66 & 56,96 & 2,65 \\
\hline 6 & 2,08 & 59,24 & 1,23 \\
\hline 7 & 8,14 & 49,25 & 4,01 \\
\hline 8 & 13,54 & 32,00 & 4,33 \\
\hline
\end{tabular}

Na Figura 14 pode-se observar que o crescimento de folhas durante o período experimental apresentou durante o verão uma média de crescimento foliar superior ao inverno. 

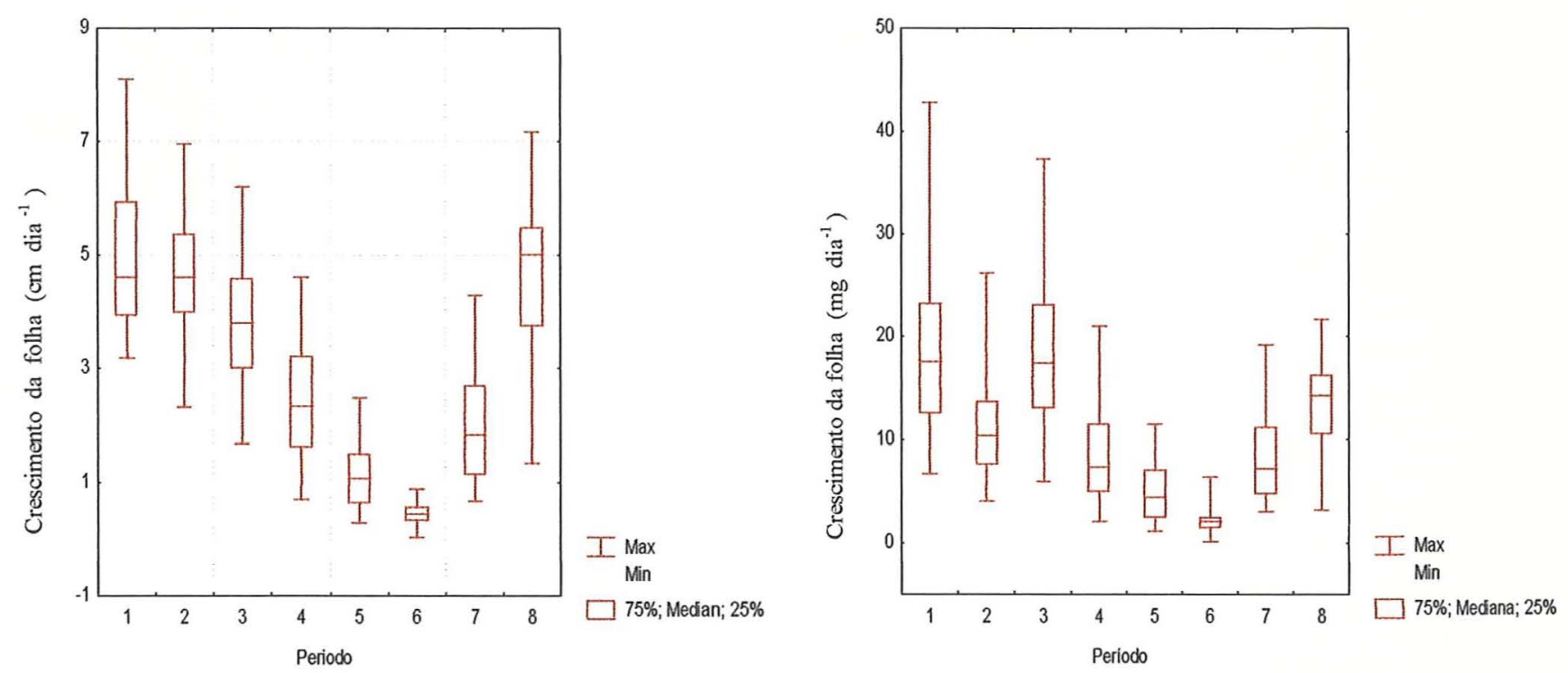

$\mathrm{P} 1=18 / 11 / 96$ a 23/12/96; $\mathrm{P} 2=27 / 12 / 96$ a 01/02/97; $\mathrm{P} 3=05 / 02 / 97$ a 13/03/97; $\mathrm{P} 4=17 / 03 / 97$ a 23/04/97; $\mathrm{P} 5=27 / 04 / 97$ a 26/06/97; $\mathrm{P} 6=03 / 07 / 97$ a $14 / 09 / 97 ; \mathrm{P} 7=21 / 09 / 97$ a $12 / 11 / 97 ; \mathrm{P} 8=19 / 11 / 97$ a $22 / 12 / 97$.

Figura 14. Crescimento das folhas do capim Tanzânia $1\left(\mathrm{~cm} \operatorname{dia}^{-1} \mathrm{e} \mathrm{mg} \mathrm{dia}{ }^{-1}\right)$ durante 0 período experimental.

$\mathrm{Na}$ Tabela 8 estão apresentadas as taxas de senescência de folhas e seus desvios padrão e coeficiente de variação. A senescência apresentou no período 1 compreendido entre os dias 18/11/96 e 23/12/96, uma média bastante elevada (cerca de $4 \mathrm{mg} \mathrm{dia}^{-1}$ ) em relação aos demais períodos, cujas médias foram inferiores a $1,2 \mathrm{mg}$ $\mathrm{dia}^{-1}$. A Figura 15 mostra uma tendência desta variável ao longo do período experimental, indicando um aumento na taxa de senescência e uma redução a partir do $6^{\underline{0}}$ e $2^{\underline{0}}$ períodos, respectivamente, alcançando índices praticamente nulos nos períodos 4 e 5 , compreendidos entre 20/03/98 e 26/06/98. Nesses períodos o metabolismo da planta diminuiu devido a falta de chuvas e baixas temperaturas. Santos (1997) trabalhando com o capim Mombaça e Tanzânia 1 observou que a partir do mês de maio a taxa de senescência foi nula. Teixeira (1998) estudando o capim Tobiatã 
obteve uma taxa de senescência maior em janeiro do que março, pois o crescimento da forragem foi superior em janeiro.

A taxa de senescência média no período do "verão" foi de 0,4 $\mathrm{cm}$ folha $\mathrm{dia}^{-1}$, representando $10 \%$ da taxa de crescimento da forragem, estando esses valores de acordo com os obtidos por Santos (1997) para o mesmo cultivar. Setelich et al. (1998a) obtiveram para o capim elefante sob pastejo uma taxa de senescência no mês de dezembro de $0,1 \mathrm{~cm}$ folha $\mathrm{dia}^{-1}$, representando $5 \%$ da taxa de crescimento.

Tabela 8. Taxas de senescência de folhas $\left(\mathrm{cm} \mathrm{dia}{ }^{-1}\right.$ e $\left.\mathrm{mg} \mathrm{dia}^{-1}\right)$ e seus desvios padrão e coeficientes de variação.

\begin{tabular}{|c|c|c|c|}
\hline Periodo & Média & CV & Desvio Padrão \\
\hline \multicolumn{4}{|c|}{ em cm folha ${ }^{-1}$ dia $^{-1}$} \\
\hline 1 & 1,05 & 99,37 & 1,05 \\
\hline 2 & 0,46 & 103,79 & 0,48 \\
\hline 3 & 0,22 & 108,89 & 0,24 \\
\hline 4 & 0,05 & 128,65 & 0,07 \\
\hline 5 & 0,03 & 126,74 & 0.04 \\
\hline 6 & 0,17 & 62,76 & 0,10 \\
\hline 7 & 0,09 & 138,83 & 0.13 \\
\hline 8 & 0.25 & 101.20 & 0.26 \\
\hline \multicolumn{4}{|c|}{ em mg folha ${ }^{-1}$ dia $^{-1}$} \\
\hline 1 & 3,97 & 101,54 & 4,03 \\
\hline 2 & 0,85 & 89,69 & 0,76 \\
\hline 3 & 1,15 & 105,83 & 1,22 \\
\hline 4 & 0.20 & 128,86 & 0,26 \\
\hline 5 & 0,18 & 132,25 & 0,24 \\
\hline 6 & 0,81 & 67,84 & 0,55 \\
\hline 7 & 0,44 & 142,80 & 0,63 \\
\hline 8 & 0.79 & 101.80 & 0.80 \\
\hline
\end{tabular}

A taxa de senescência apresentou altos valores de coeficiente de variação, pois trata-se de uma medida indireta, onde se mede a parte verde da folha e, por não ser um local exato e sim gradual na 
folha, a chance de variação se torna maior. Além disso, são poucas as folhas que senescem, o que contribui para o aumento na variabilidade dos dados.

A comparação entre os resultados apresentados nas tabelas 7 e 8 indicam que as taxas de acúmulo de matéria seca de folhas foram de $19,4 \mathrm{mg}$ folha $^{-1} \mathrm{dia}^{-1}$ no período 1 e $11,1 \mathrm{mg}$ folha ${ }^{-1} \mathrm{dia}^{-1}$ no período 2, enquanto que as taxas de senescência foram 3,9 e $0,8 \mathrm{mg}$ dia $^{-1}$ folha $^{-1}$. Esses dados mostram que, apesar da ocorrência da senescência está ocorrendo acúmulo líquido de produção de folhas, indicando que o Tanzânia 1 pode suportar cortes menos freqüentes do que 36 dias no "verão" sem prejuízos na produção de matéria seca. Resta avaliar o efeito do período de descanso maior do que 36 dias no "verão" sobre a qualidade e aproveitamento da forragem disponível.
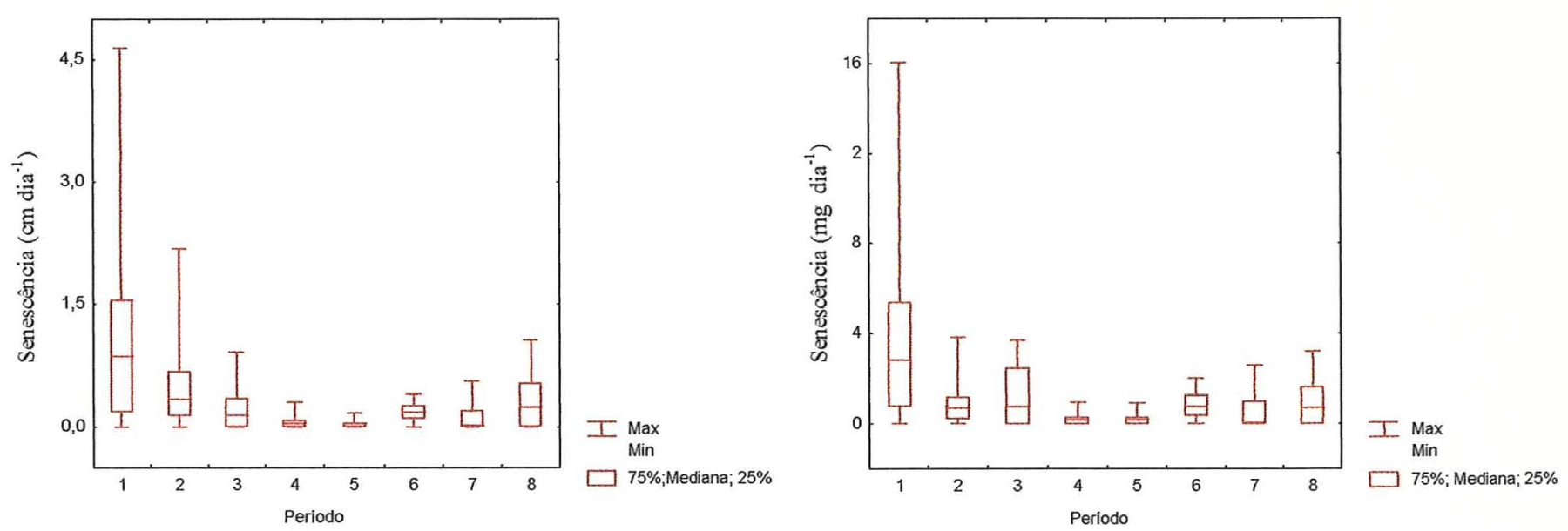

$\mathrm{P} 1=18 / 11 / 96$ a 23/12/96; $\mathrm{P} 2=27 / 12 / 96$ a $01 / 02 / 97 ; \mathrm{P} 3=05 / 02 / 97$ a $13 / 03 / 97 ; \mathrm{P} 4=17 / 03 / 97$ a 23/04/97; $\mathrm{P} 5=27 / 04 / 97$ a $26 / 06 / 97 ;$ $\mathrm{P} 6=03 / 07 / 97$ a $14 / 09 / 97 ; \mathrm{P} 7=21 / 09 / 97$ a $12 / 11 / 97 ; \mathrm{P} 8=19 / 11 / 97$ a $22 / 12 / 97$.

Figura 15. Senescência de folhas $\left(\mathrm{cm} \mathrm{dia}^{-1} \mathrm{e} \mathrm{mg} \mathrm{dia}^{-1}\right)$ do capim Tanzânia 1 durante o período experimental. 
A taxa de acúmulo de matéria seca a partir da avaliação de fluxo de tecidos (método não destrutivo) foi 79,$92 ; 53,93 ; 71,00$; 48,$64 ; 30,84 ; 7,45 ; 45,88$ e $92,27 \mathrm{~kg} \mathrm{MS} \mathrm{ha}{ }^{-1}$ para os períodos de pastejo de 1 a 8 , respectivamente. Os resultados obtidos foram satisfatórios quando comparados aos dados de cortes de forragem (método destrutivo), já que as curvas apresentaram a mesma tendência, como pode ser observado na Figura 16. Carnevalli \& da Silva (no prelo) trabalhando com fluxo de tecidos com Cynodon dactylon obtiveram resultados bastante satisfatórios que puderam ser relacionados com os dados de corte, mostrando a mesma tendência ao longo do período experimental. Porém, o fato de Carnevalli \& da Silva (no prelo) terem avaliado o fluxo de tecidos somente antes do pastejo fez com que os dados fossem superestimados, enquanto que nesse trabalho a avaliação do fluxo de tecidos foi uma medida entre o início e o final do período de descanso. Desse modo os resultados deste trabalho caracterizam média de taxas de crescimento da planta durante o período de pastejo.

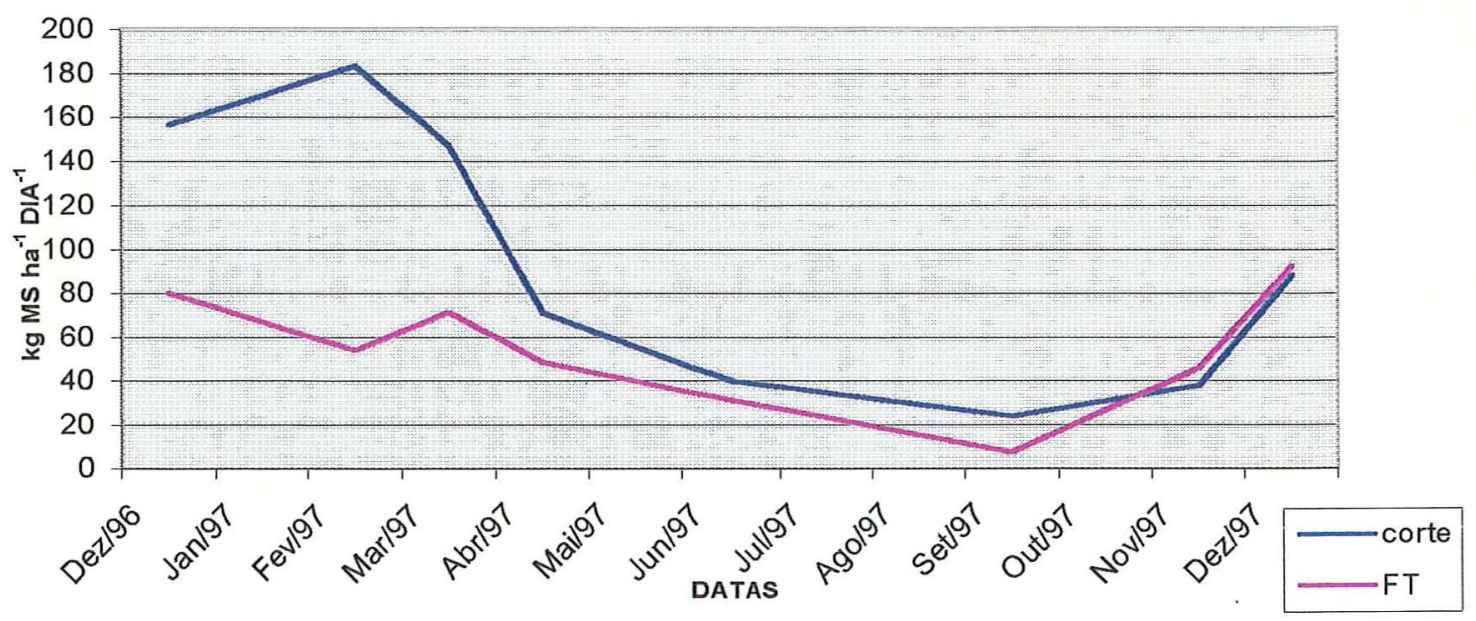

Figura 16. Comparação entre taxas de acúmulo de matéria seca $\left(\mathrm{kg} \mathrm{ha}^{-1}\right)$ no capim Tanzânia 1 determinadas através de cortes e fluxo de tecidos (FT). 
Assim, fica demonstrado que no "verão" a planta apresentou taxas de acúmulo diferentes entre o início e o final do período de descanso, enquanto que no "inverno" essa diferença na taxa de crescimento é menor.

Com relação ao número de folhas vivas por perfilho, não verificou nenhuma tendência ao longo dos períodos (Tabela 9). A média permaneceu em torno de 4 folhas (Figura 17). Apenas no $6^{0}$ período observou-se uma queda na média (2,7 folhas). Teixeira (1998) trabalhando com capim Tobiatã, observou uma redução no número de folhas vivas expandidas perfilho ${ }^{-1}$ nos períodos finais de pastejo (março). Esse autor obteve um número médio de 4,5 folhas vivas perfilho ${ }^{-1}$ durante o verão.

A literatura fornece alguns valores de número de folhas vivas por perfilho em $P$. maximum tais como: 4,6 no cultivar Guiné (Pinto, 1993), 4,0 e 6,0 para o Mombaça e Vencedor, respectivamente (Gomide, 1997) e 5,2 em Tanzânia 1 (Santos, 1997).

O número de folhas vivas perfilho ${ }^{-1}$ é razoavelmente constante dentro do genótipo, dependendo das condições do meio e do manejo. Daí, tal índice prestar-se para orientar sobre a determinação da freqüência de corte ou pastejo das forrageiras tendo em vista a maximização da eficiência de colheita, evitando-se assim perdas por senescência e morte (Gomide, 1997). Segundo Lemaire \& Chapman (1996), como o número de folhas vivas perfilho-1 é constante, o equilíbrio entre produção e senescência só seria atingido quando as folhas senescentes apresentassem tamanho semelhante àquelas em expansão. Entretanto, Santos (1997) relatou que para o capim Tanzânia 1 ainda não foi determinado como esse equilíbrio é 
atingido, porém, foi possível prever através das informações de Gomide \& Gomide (1996) que isso só iria ocorrer com mais de 100 dias de crescimento, indicando que a definição da freqüência de pastejo nesta forrageira seria determinada, provavelmente, em conseqüência da redução do valor nutricional da planta com a maturidade e/ou decréscimo na utilização da forragem disponível com o avanço da maturidade da planta.

Tabela 9. Médias de número de folhas vivas por perfilho e seus desvios padrão e coeficientes de variação.

\begin{tabular}{|c|c|c|c|}
\hline Periodo & $\begin{array}{c}\text { Média (folhas } \\
\text { perf }^{1} \text {.) }\end{array}$ & CV & Desvio Padrão \\
\hline 1 & 4,20 & 15,79 & 0,66 \\
\hline 2 & 4,10 & 21,57 & 0,89 \\
\hline 3 & 3,70 & 17,87 & 0,67 \\
\hline 4 & 4,30 & 25,79 & 1,10 \\
\hline 5 & 4,40 & 28,27 & 1,23 \\
\hline 6 & 2,70 & 23,91 & 0,64 \\
\hline 7 & 4,03 & 19,88 & 0,80 \\
\hline 8 & 4,40 & 15.20 & 0,66 \\
\hline
\end{tabular}

As taxas de aparecimento de folhas (dias folha ${ }^{-1}$ ) e seus coeficientes de variação e desvios padrão estão apresentadas na Tabela 10 .

A Figura 17 evidencia os períodos menos favoráveis para o aparecimento das folhas. Os períodos 5 e 6 (27/04/97 à 14/09/97), com médias de 30,5 e 55,5 dias folha $^{-1}$, respectivamente, apresentam uma alta variabilidade nos dados e com desvios padrão em torno de 16,0 dias folha ${ }^{-1}$. Nos demais períodos, há uma regularidade no aparecimento das folhas com médias oscilando entre 10,2 a 12,0 dias 
folha $^{-1}$ e baixa variabilidade nos períodos, principalmente na época de verão (18/11/96 a 13/03/97), contrastando com os períodos 5 e 6 . A baixa taxa de aparecimento de folhas no período 6 (55 dias folha ${ }^{-1}$ ) ocasionou queda no número de folhas vivas perfilho ${ }^{-1}$ no mesmo período. A diminuição na taxa de aparecimento de folhas ocorreu devido as limitações dos fatores de crescimento no período (Figura 1). A taxa de aparecimento de folhas é influenciada principalmente pela estação do ano (Parsons \& Penning, 1988) e pela temperatura (Collins \& Jones, 1988). Barbosa et al. (1997) encontraram grande variação das taxas de aparecimento de folhas para o capim Tobiatã em função da época do ano. Esses autores estimaram, através de regressão linear para um período de crescimento de 35 dias, as seguintes taxas de aparecimento de folhas: $10 ; 8,3 ; 9,1$ e 12,5 dias folha $^{-1}$ para a estação de inverno, primavera, verão e outono, respectivamente. Teixeira (1998) obteve durante o período experimental, com o capim Tobiatã pastejado no período de verão, taxa média de aparecimento de folhas de 10,2 dias folha $^{-1}$. Gomide \& Gomide (1996) observaram valores de 6,66 e 5,26 dias folha ${ }^{-1}$ nos cultivares Mombaça e Tanzânia 1 durante $o$ período de estabelecimento do pasto. 
Tabela 10. Taxas de aparecimento de folhas (dias folhas ${ }^{-1}$ ) e seus desvios padrão e coeficientes de variação.

\begin{tabular}{|c|c|c|c|}
\hline Periodo & Média & CV & Desvio Padrão \\
\hline 1 & 10,17 & 19,46 & 1,98 \\
\hline 2 & 11,96 & 27,72 & 3,31 \\
\hline 3 & 12,26 & 24,40 & 2,99 \\
\hline 4 & 14,87 & 41,88 & 6,23 \\
\hline 5 & 30,50 & 51,13 & 15,60 \\
\hline 6 & 55,46 & 29,87 & 16,57 \\
\hline 7 & 18,99 & 47,51 & 9,02 \\
\hline 8 & 12,03 & 35,20 & 4,23 \\
\hline
\end{tabular}

$O$ intervalo entre desfolhas de um pasto pode ser calculado pelo filocrono e pelo número de folhas que um perfilho consegue manter (Corsi, 1993; Corsi et al., 1994). Por esse motivo, vários trabalhos vêm sendo realizados com o objetivo de determinar esses valores em espécies forrageiras (Barbosa et al., 1996; Gomide \& Gomide, 1996).

Os dados observados para o capim Tanzânia 1 neste experimento, por serem fruto de uma situação específica de manejo, não devem ser utilizados como guia de manejo dessa gramínea sob pastejo. No entanto, é interessante exemplificar como as características observadas poderiam servir em aspectos práticos de manejo. Considerando-se um número médio de 4,0 folhas vivas perfilho-1 $^{-1}$ no capim Tanzânia 1 (média do período experimental) e que cerca de 1,5 folhas vivas são deixadas após o pastejo (média dos períodos de pastejo), os perfilhos teriam que produzir mais 2,5 folhas para alcançarem o valor médio de folhas perfilho ${ }^{-1}$. Utilizando esse valor e multiplicando-se pelo período de dias necessários para formar uma folha, obtêm-se os seguintes períodos de descanso: 25,4;30,0; 
30,$6 ; 37,25 ; 76,25 ; 137,0 ; 47,5$ e 30,0 dias para os períodos de 1 a 8 (Dezembro-96 à Novembro-97), respectivamente. Para a execução desse trabalho no entanto os períodos de descanso utilizados foram, respectivamente: $36,36,37,38,58,72,53$ e 37 .
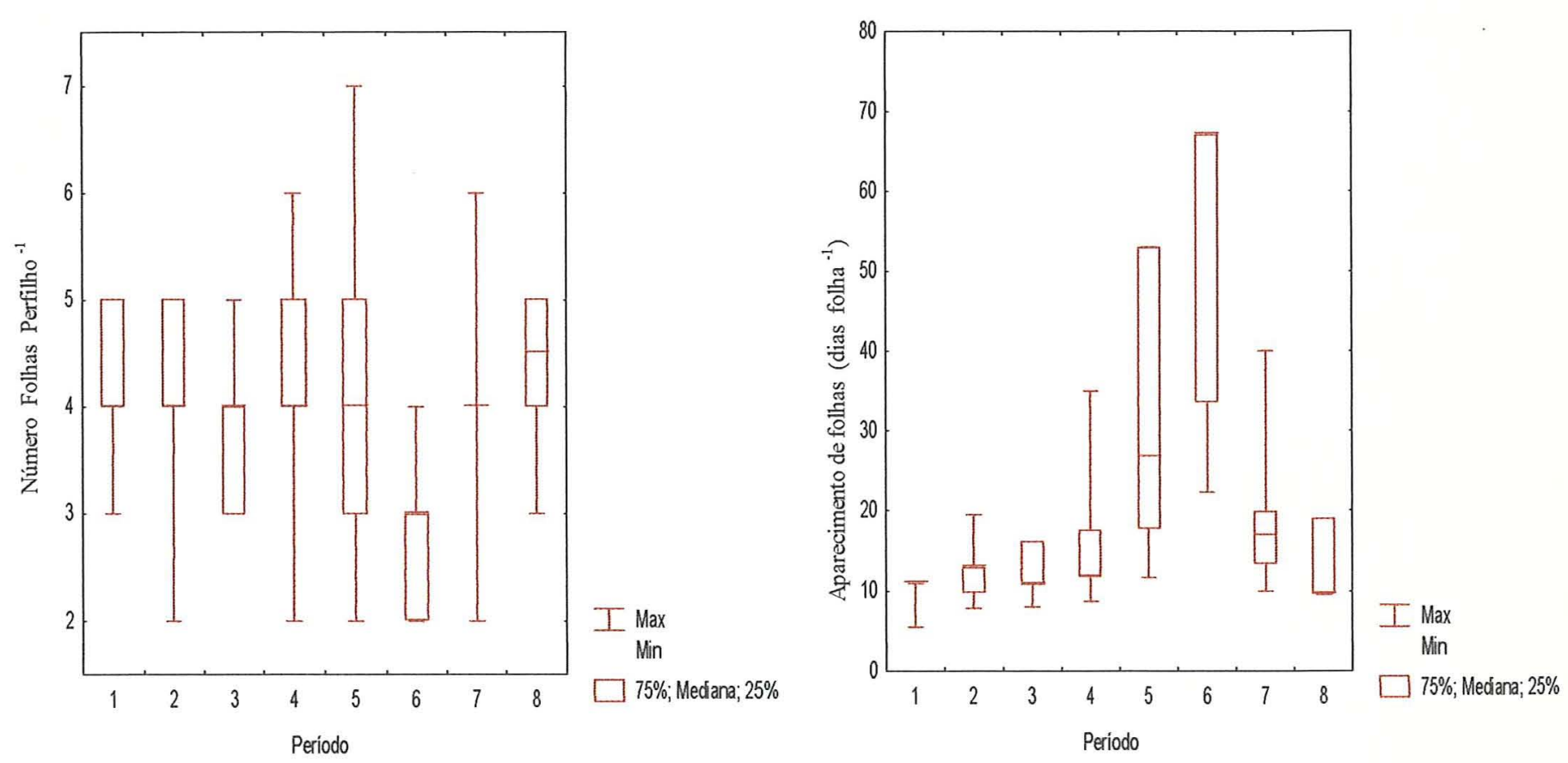

$\mathrm{P} 1=18 / 11 / 96$ a 23/12/96; $\mathrm{P} 2=27 / 12 / 96$ a $01 / 02 / 97 ; \mathrm{P} 3=05 / 02 / 97$ a 13/03/97; $\mathrm{P} 4=17 / 03 / 97$ a $23 / 04 / 97 ; \mathrm{P} 5=27 / 04 / 97$ a $26 / 06 / 97 ;$ $\mathrm{P} 6=03 / 07 / 97$ a $14 / 09 / 97 ; \mathrm{P} 7=21 / 09 / 97$ a $12 / 11 / 97 ; \mathrm{P} 8=19 / 11 / 97$ a $22 / 12 / 97$.

Figura 17. Número de folhas vivas por perfilho e taxas de aparecimento de folhas (dias folha ${ }^{-1}$ ) no capim Tanzânia 1 durante o período experimental.

Em termos práticos o uso de período de descanso variável implicaria em acrescentar ou excluir piquetes da área de pastejo à medida que as condições de ambiente se modificassem.

No entanto, é preciso lembrar que o número de folhas por perfilho e o filocrono não constituem por si só um princípio de manejo. A idéia da adoção desses valores para nortear o manejo dos 
pastos surgiu das recomendações que têm sido feitas para o azevém perene. Neste capim, a desfolha deve ser feita quando se completa a expansão de três folhas, que é o número máximo de folhas que um perfilho consegue manter. Essa recomendação, no entanto, se baseia em que, após o aparecimento da terceira folha, a taxa de senescência equilibra-se com a de aparecimento de folhas resultando em uma taxa zero de acúmulo líquido de matéria seca (Davies, 1971). Para o caso do capim Tanzânia 1, no entanto, o início da senescência de folhas não parece indicar com a mesma precisão a freqüência entre pastejos como ocorre com o azevém perene. No capim Tanzânia 1 o início da senescência não significa redução na taxa de acúmulo líquido, uma vez que as primeiras folhas desta gramínea sạo muito menores do que as folhas que aparecem mais tarde durante o período de "verão".

\subsection{Ganho de peso vivo e produtividade animal}

As médias da variável ganho de peso vivo durante os períodos das "águas" (27/11/96 à 28/04/97) e da "seca" (29/04/97 à 30/11/97) e seus respectivos desvios padrão e coeficientes de variação podem ser observadas na Tabela 11. 
Tabela 11. Médias de ganho de peso $\left(\mathrm{kg}\right.$ animal $\left.{ }^{-1} \mathrm{dia}^{-1}\right)$ nos períodos das "águas" e da "seca" e seus desvios padrão, coeficientes de variação e peso médio inicial e final dos animais.

\begin{tabular}{|c|c|c|c|c|c|}
\hline $\begin{array}{l}\text { Ganho de } \\
\text { Peso }\end{array}$ & $\begin{array}{c}\text { Media } \\
\text { (kg animal } \text { dia }^{-1} \text { ) }\end{array}$ & $\mathrm{CV}$ & $\begin{array}{l}\text { Desvio } \\
\text { Padrão }\end{array}$ & $\begin{array}{l}\text { Peso médio } \\
\text { iniclal (kg) }\end{array}$ & $\begin{array}{l}\text { Peso medio } \\
\text { final (kg) }\end{array}$ \\
\hline Águas & 0,82 & 13,54 & 0,107 & 338 & 455 \\
\hline Seca & 0,54 & 25,18 & 0,136 & 258 & 344 \\
\hline
\end{tabular}

"Águas" = 27/11/96 à 28/04/97, "Seca" = 29/04/97 à 30/11/97.

A produtividade de $1370 \mathrm{~kg} \mathrm{PV} \mathrm{ha-1}$ ano $^{-1}$ obtida nesse experimento (Figura 19) pode ser considerada excelente, já que a média anual do país é de 90 a $120 \mathrm{~kg} \mathrm{PV} \mathrm{ha}^{-1} \mathrm{ano}^{-1}$. Euclides (1995) trabalhando com ganho de peso por animal em pastagem de capim Tanzânia 1 obteve uma produtividade de 450 e $650 \mathrm{~kg} \mathrm{PV} \mathrm{ha}^{-1}$ ano $^{-1}$ com níveis de adubação de 400 e $800 \mathrm{~kg} \mathrm{~N} \mathrm{ha}^{-1}$ ano $^{-1}$. Favoretto et al. (1985) trabalhando com capim Colonião em sistema rotacionado obtiveram uma produtividade de $400 \mathrm{~kg} \mathrm{PV} \mathrm{ha}^{-1} \mathrm{ano}^{-1}$, enquanto que Jank (1994) em experimento conduzido em Campo Grande- MS obteve $450 \mathrm{~kg} \mathrm{PV} \mathrm{ha}^{-1}$ ano $^{-1}$ para o capim Tanzânia 1.

Esta elevada produtividade está relacionada com a alta produção de matéria seca $\left(29,6 \mathrm{t} \mathrm{MS} \mathrm{ha}^{-1} \mathrm{ano}^{-1}\right.$, Figura 2), alto valor nutritivo da forragem (Figuras 5, 6, e 7) e um bom desempenho dos animais que apresentaram um ganho de peso médio de 0,82 e $0,53 \mathrm{~kg}$ animal $^{-1}$ dia $^{-1}$ nos períodos das "águas" e "seca" (Tabela 11), respectivamente. Essa redução observada entre os ganhos de peso do período da águas e da seca esta relacionada com a redução da disponibilidade média de MS de forragem de 4,6\% para 3,9\% do peso vivo nos períodos das "águas" e da "seca", respectivamente, e 
também com a queda no valor nutritivo da forragem ocasionada pelo efeito da maturação da forragem (figuras 5, 6, e 7). Euclides et al. (1993a; 1993b) apresentaram, para os capins Colonião, Tobiatã e Tanzânia 1, ganhos de peșo vivo elevados entre outubro a março de 0,$672 ; 0,650$ e $0,720 \mathrm{~kg} \operatorname{animal}^{-1} \mathrm{dia}^{-1}$ e observaram que fora da estação de crescimento os ganhos foram 0,$240 ; 0,205$ e $0,290 \mathrm{~kg}$ animal ${ }^{-1} \mathrm{dia}^{-1}$, respectivamente, concluindo que esse ganho inferior ocorreu pelo efeito da maturação da forragem. Setelich et al.(1998b) trabalhando com capim elefante anão adubado com $500 \mathrm{~kg}$ de $\mathrm{N} \mathrm{ha}^{-1}$ ano $^{-1}$ durante o período de crescimento, utilizando animais da raça Charolês $\mathrm{x}$ Nelore com peso médio inicial de $160 \mathrm{~kg}$, obteveram ganho de $1,0 \mathrm{~kg}$ animal ${ }^{-1} \mathrm{dia}^{-1}$ utilizando uma lotação de $3,7 \mathrm{UA} \mathrm{ha}^{-1}$. Postiglioni (1997) trabalhando com método contínuo de pastejo e animais mestiços da raça Canchin com peso médio inicial de $170 \mathrm{~kg}$ obteve, durante os períodos da primavera, verão e outono, médias de 0,6 e $0,59 \mathrm{~kg}$ animal ${ }^{-1} \mathrm{dia}^{-1}$ para os capins $B$. Brizantha e Coastcross, respectivamente, observando variações no ganho de peso nos diferentes períodos associando às variações do valor nutritivo da forragem.

A disponibilidade e o valor nutritivo da forragem que foram utilizados neste experimento permitiram taxas de lotação médias de 6,6 e 2,7 UA ha ${ }^{-1}$ nos períodos das "'águas" e da "seca", respectivamente, proporcionando taxa média anual de 4,8 $\mathrm{UA} \mathrm{ha}^{-1}$. As lotações observadas durante o período experimental foram: 4,2; 5,$4 ; 6,4 ; 7,9 ; 9,1 ; 9,5 ; 7,9 ; 6,0 ; 4,8 ; 5,1 ; 4,1 ; 3,0 ; 1,5 ; 1,6 ; 1,8 ; 2,7$ e 5,1 UA ha ${ }^{-1}$ (Figura 18). Alguns autores trabalhando com $P$. maximum obtiveram alguns valores médios de taxa de lotação, como: 
2,2 e 1,7 UA ha-1 para o capim Colonião em sistema de pastejo contínuo e rotacionado, respectivamente (Quinn et al., 1961; Favoretto et al., 1985) e 5,2 e 4,7 $\mathrm{UA} \mathrm{ha}^{-1}$ para o Mombaça e Tanzânia 1 em sistema de pastejo rotacionado (Euclides, 1995). De acordo com Corsi \& Santos (1995) há razões para se acreditar em níveis de lotação entre 12 e $15 \mathrm{UA} \mathrm{ha}^{-1}$, durante o verão, e de 3 a 4 $\mathrm{UA} \mathrm{ha} \mathrm{C}^{-1}$ no inverno.

Veiga (1994) trabalhando com capim elefante cv. Mott obteve lotação média de 4,7 $\mathrm{UA} \mathrm{ha}^{-1}$ com ganho de peso vivo médio de 0,970 g dia ${ }^{-1}$ durante 3 anos. Hill et al. (1993) trabalhando com Tifton 85 durante o verão, adubado com $250 \mathrm{~kg} \mathrm{~N} \mathrm{ha}^{-1}$ ano $^{-1}$, obtiveram média de lotação e ganho de peso de 7,8 UA ha ${ }^{-1}$ e 0,670 animal $^{-1}$ dia $^{-1}$, utilizando animais com peso inicial de $325 \mathrm{~kg}$.

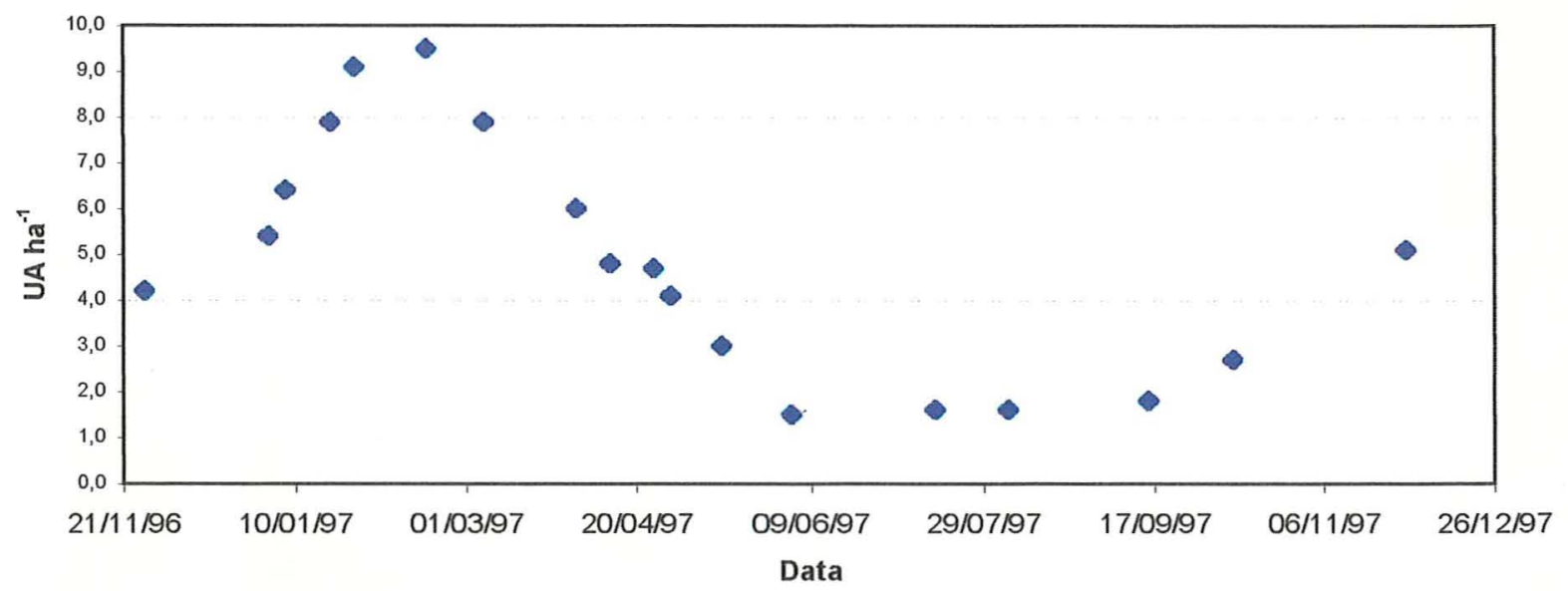

Figura 18. Variação da lotação (UA ha ${ }^{-1}$ ) nos períodos das "águas" (27/11/96 à 28/04/97) e da "seca" (29/04/97 à 30/11/97) no capim Tanzânia 1.

O ganho de peso relatado na literatura para as plantas do gênero Cynodon estão contidos em intervalos em torno de 0,45 a $0,90 \mathrm{~kg}$ animal $^{-1}$ dia $^{-1}$ (Pitman et al., 1984; Corrêa, 1997). Guerrero et al. 
(1984) trabalhando com Callie bermuda em sistema rotacionado, utilizando adubação $224 \mathrm{~kg}$ de $\mathrm{N} \mathrm{ha}^{-1}$ ano $^{-1}$, obteve ganho de peso e taxa de lotação média de $0,90 \mathrm{~kg}$ animal $^{-1} \mathrm{dia}^{-1}$ e 2,8 UA ha ${ }^{-1}$, com novilhas com peso médio de $219 \mathrm{~kg}$.

A taxa de lotação no presente experimento apresentou marcada estacionalidade explicada pela variação na produção de matéria seca (Figura 2) e pelo valor nutritivo da forragem.

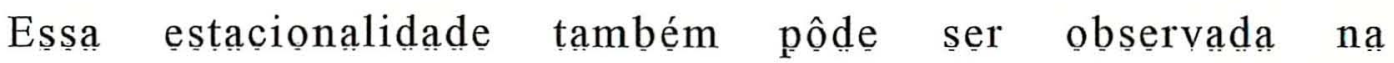
produtividade, que foi de 910 e $460 \mathrm{~kg} \mathrm{PV} \mathrm{ha}^{-1}$ no período das "águas" e da "seca", respectivamente (Figura 19). A produtividade máxima foi atingida no mês de janeiro (250 $\mathrm{kg} \mathrm{PV} \mathrm{ha}^{-1}$ ) e a mínima nos meses de julho, agosto e setembro (38 $\left.\mathrm{kg} P V \mathrm{ha}^{-1}\right)$. A produtividade obtida no período "seco" foi $33 \%$ da anual. Hill et al. (1993) obtiveram com Tifton 85 uma produtividade de $1150 \mathrm{~kg}$ PV ha ${ }^{-1}$ em 169 dias de pastejo durante o "verão".

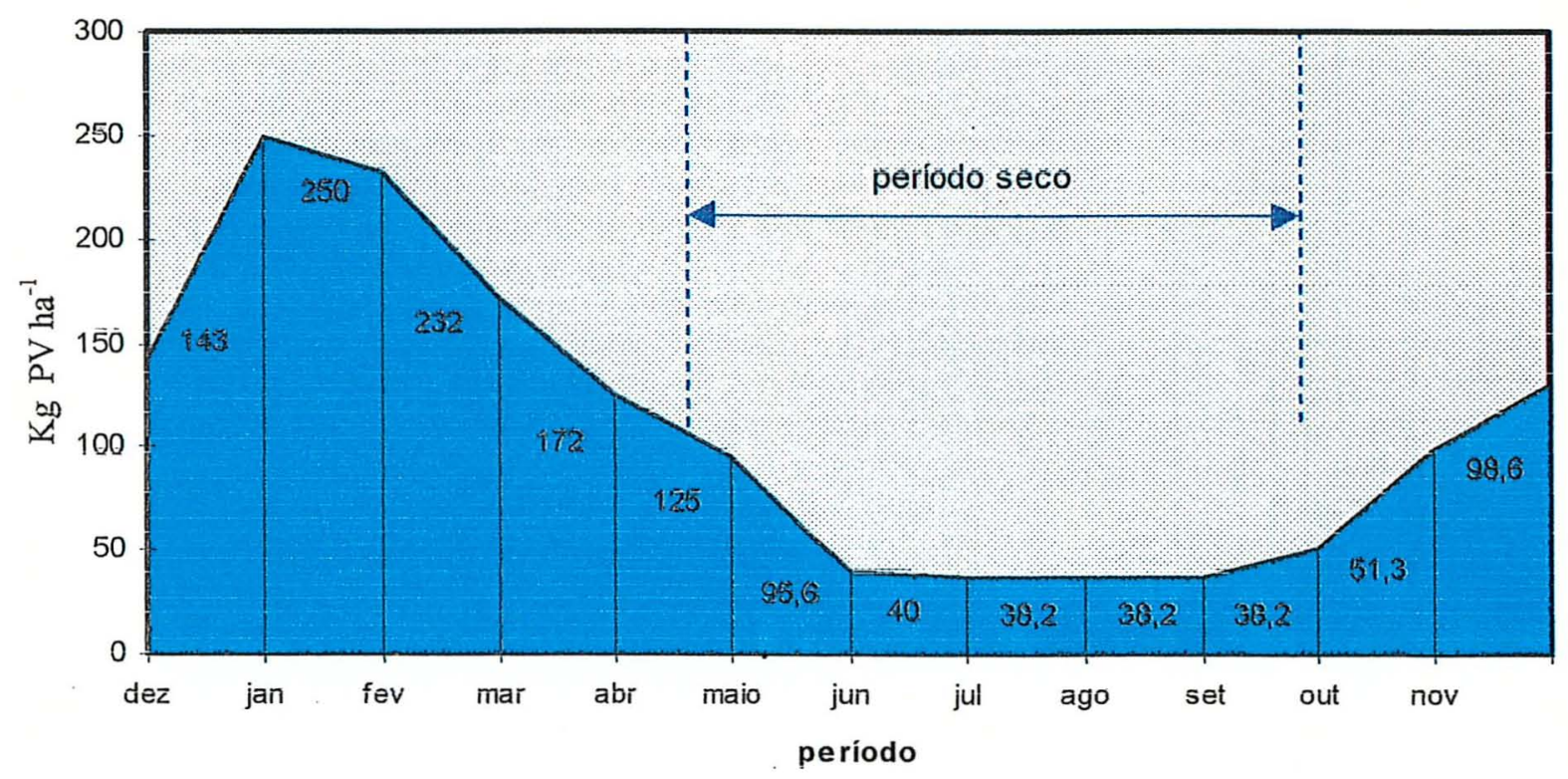

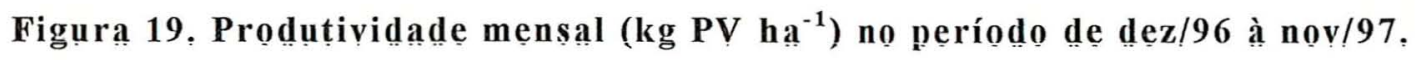


O valor da produtividade anual $\left(1370 \mathrm{~kg} \mathrm{PV} \mathrm{ha}^{-1} \mathrm{ano}^{-1}\right)$ está próximo das metas sugeridas por Corsi \& Santos (1995), que apontam para a possibilidade de se obter, através da utilização de novos cultivares de $P$. maximum aliados a alterações no manejo, níveis de produtividade de 1590 à $1980 \mathrm{~kg} \mathrm{PV} \mathrm{ha}^{-1} \mathrm{ano}^{-1}$. 


\section{AVALIAÇÃo ECONÔMICA}

As Tabelas 12 e 13 apresentam as análises econômicas dos períodos das "águas" e da "seca", respectivamente. O valor de compra e venda dos animais foi estabelecido de acordo com o preço vigente da arroba do boi (@) uma vez que o mercado brasileiro comercializa aniamais em @ (15 kg de carcaça). No período das "águas" os animais foram comprados a US\$23,25 @ ${ }^{-1}$ e vendidos a US\$24,18 @ $@^{-1}$ e na "seca" foram comprados e vendidos a US\$ 24,18 $\varliminf^{-1}$. Para referência, considerou-se juros de $6 \%$ ao ano para os investimentos que foram amortizados e o dólar cotado a $\mathrm{R} \$ 1,07$.

Tabela 12. Análise econômica do período das "águas" no sistema de pastejo rotacionado com o capim Tanzânia 1

\begin{tabular}{lrrrrr}
\hline & quantid & Custo US\$ & Total US\$ & Depreciaça \\
\hline formação do pasto $(\mathrm{ha})$ & 8 & 341.14 & 2729.12 & 20 & anos \\
cerca eletrificada $(\mathrm{km})$ com aparelho & 2,1 & 325.58 & 683.72 & 10 anos \\
cerca convencional $(\mathrm{km})$ & 1,3 & 1332.09 & 1731.72 & 10 anos \\
bebedouro australiano & 1 & 734.88 & 734.88 & 10 anos \\
\hline compra de animais (nov. 1996) & 89 & 258.37 & 22995.12 & \\
venda de animais (fev. 1997) & 20 & 260.20 & 5204.03 & \\
venda de animais (mar. 1997) & 16 & 312.56 & 5000.90 & \\
venda de animais (inicio abr. 1997) & 13 & 350.96 & 4562.53 & \\
venda de animais (final abr. 1997) & 40 & 381.66 & 15266.49 & \\
\hline adubo (US\$ ha') & 8 & 390.70 & 3125.58 & \\
sal mineral (kg no periodo) & 293 & 0.44 & 128 & \\
trator para adubação (h/ 5 meses) & 25 & 11.16 & 279 & \\
vacinas/medicamentos & & & 153.99 & \\
mão de obra (homem mês ${ }^{-1}$ ) & 0,2 & 279.07 & 336.36 & \\
\hline amortização anual do pasto & 5 meses & 252.21 & 105.10 & \\
amortização anual de cercas & 5 meses & 347.87 & 144.95 & \\
amortização anual do bebedouro & 5 meses & 105.84 & 44.10 & \\
\hline
\end{tabular}


Tabela 13. Análise econômica do período da "seca" no sistema de pastejo rotacionado com o capim Tanzânia 1

\begin{tabular}{|c|c|c|c|c|c|}
\hline & quantid. & Custo US\$ & Total US\$ & deprec & iação \\
\hline formação do pasto (ha) & 8 & 341.14 & 2729.15 & 20 & anos \\
\hline cerca eletrificada $(\mathrm{km})$ com aparelho & 2,1 & 325.58 & 683.72 & 10 & anos \\
\hline cerca convencional $(\mathrm{km})$ & 1,3 & 1332.09 & 1731.72 & 10 & anos \\
\hline bebedouro australiano & 1 & 734.88 & 734.88 & 10 & anos \\
\hline Compra de animais (@) (maio 1997) & 830,0 & 24.19 & 20074.42 & & \\
\hline Venda de animais (@) (dez 1997) & 952,1 & 24.19 & 23027.53 & & \\
\hline calcário (US\$ ha ${ }^{-1}$ ) & 8 & 34.88 & 279.07 & & \\
\hline sal mineral $(\mathrm{kg})$ & 356,9 & 0.326 & 116.19 & & \\
\hline trator - distr. calcário (h mês ${ }^{-1}$ ) & 3 & 11.16 & 33.49 & & \\
\hline vācinas/medicamentos & & & 99.08 & & \\
\hline mão de obra (homem mês ${ }^{-1}$ ) & 0,2 & 353.49 & 494.9 & & \\
\hline amortização anual do pasto & 7 meses & 252.21 & 147.14 & & \\
\hline amortização anual de cercas & 7 meses & 347.87 & 202.92 & & \\
\hline amortização anual do bebedouro & 7 meses & 105.81 & 61.74 & & \\
\hline
\end{tabular}

"Aguas" = 27/11/96 à 28/04/97, "Saea" $=29 / 04 / 97$ à 30/11/97.

Para a determinação do lucro $\mathrm{ha}^{-1}$ do sistema durante o período experimental, as despesas foram subtraídas da receita das vendas dos animais. Nesse custo não foi contabilizada a remuneração da terra.

No período das "águas" o custo de produção foi superior ao período da "seca", devido a despesas com fertilizantes e sua aplicação na área. Não obstante, através da adubação intensa (320 kg de $\mathrm{N} \mathrm{ha}^{-1} \mathrm{ano}^{-1}$ ), foi possível manter alta lotação nas pastagens, que proporcionou maior produtividade de carne por unidade de área, redundando em maior lucro no período das "águas".

O lucro de US\$530.04 $\mathrm{ha}^{-1}$ (Tabela 14) no período de um ano demonstra que o sistema de produção de carne, através do pastejo rotacionado do capim Tanzânia 1 sob intensa adubação apresenta viabilidade, como foi demonstrado no presente ensaio. 
Tabela 14. Lucratividade do sistema de pastejo rotacionado com capim Tanzânia 1 no período de dezembro de 1996 à novembro 1997.

\begin{tabular}{lrr|r}
\hline PERIOODOS & "ÁGUAS" & "SECA" & TOTAL \\
\hline Custo da arroba produzida a pasto & 15.21 & US\$ & 13.51 \\
Custo por hectare & 486.87 & 127.76 & 615.63 \\
Lucro por hectare no período & 340.22 & 189.82 & 530.04 \\
\hline
\end{tabular}

"Águas" = 27/1 1/96 à 28/04/97, "Seca" = 29/04/97 à 30/11/97.

A Figura 20 apresenta a composição relativa dos custos de produção de carne. Pode-se observar que a adubação representa o item de maior dispêndio, sendo o preço de compra desse insumo, sua formulação e qualidade fatores de grande importância para a formação do custo de produção do sistema de pastejo rotacionado.

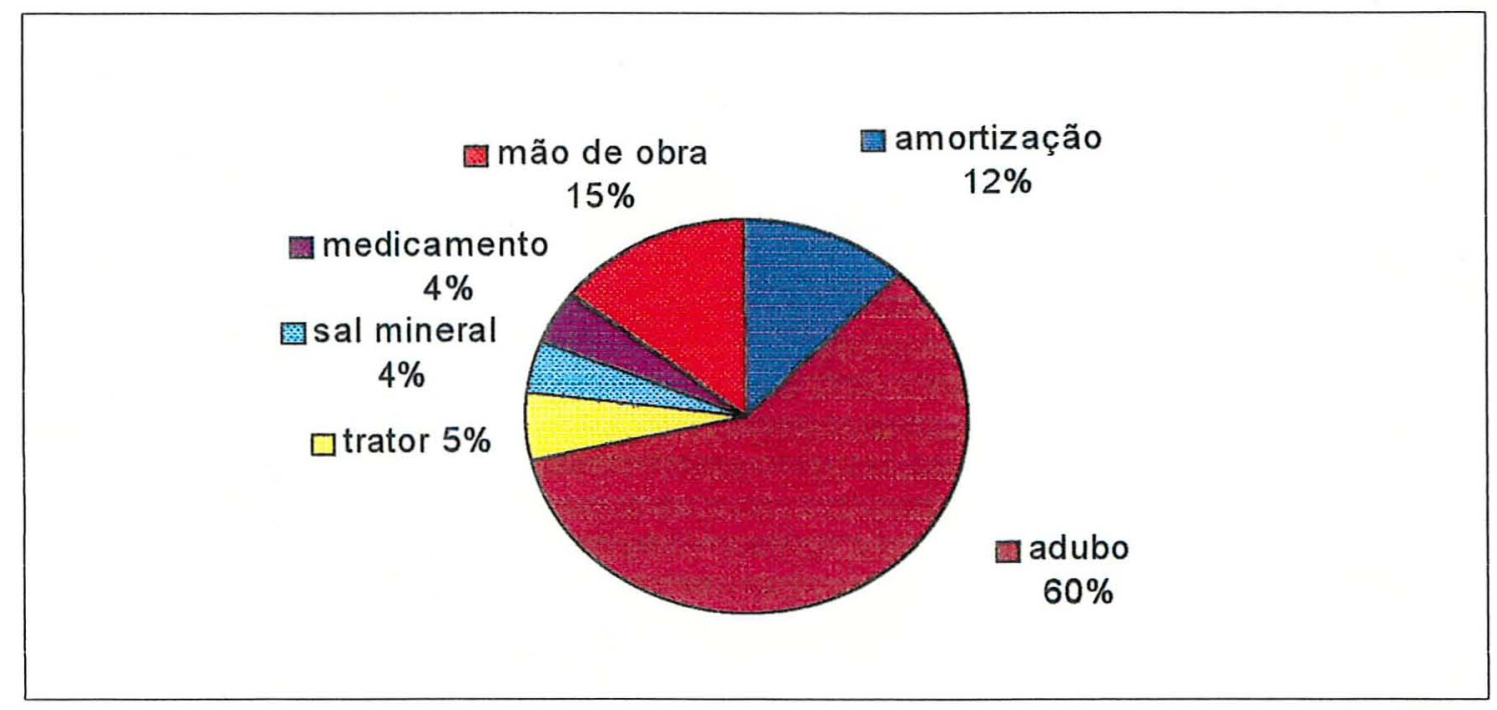

Figura 20. Composição relativa dos custos de produção de carne em pastagem de capim Tanzânia 1 no período de dezembro de 1996 a dezembro de 1997. 


\section{CONCLUSÕES}

A cultivar Tanzânia 1 de $P$. maximum revelou-se altamente produtiva no sistema de pastejo rotacionado adotado, possibilitando taxas de lotação médias de 6,6 e 2,7 $\mathrm{UA} \mathrm{ha}^{-1}$ e produção de carne da ordem de 910 e $460 \mathrm{~kg}$ PV ha" no período das "águas" e "seca", respectivamente.

A distribuição da produção de massa seca do capim Tanzânia 1 ficou concentrada nas "águas" (cerca de $80 \%$ ), caracterizando-a como forrageira de "verão". Em função disso seu uso deve ser otimizado na estação de crescimento.

A qualidade nutricional do capim Tanzânia 1 sofreu significativa redução no período da "seca", como demonstraram os valores de digestibilidade verdadeira "in vitro" da matéria seca e os teores de proteína bruta. Muito embora tenha havido redução na qualidade do material, os valores de digestibilidade e proteína encontrados no presente experimento, são considerados elevados, quando comparados com as médias de gramíneas tropicais relatadas na literatura.

As perdas de forragem pelo pastejo foram quantitativamente maiores nos período de maior produção de matéria seca, porém, em porcentagem da produção as perdas foram maiores nos períodos de final da "seca", devido ao acúmulo de material morto não decomposto que é derrubado pela ação do pastejo. Possivelmente uma das maneira de se amenizar esse problema durante o pastejo, seria manter o resíduo pós-pastejo em uma altura menor do que a utilizada 
$(35-40 \mathrm{~cm})$. Entretanto para a execução desse tipo de manejo é necessário melhor controle do desenvolvimento das hastes no período inicial do "verão" (Dezembro a Fevereiro) e elevar o nível de fertilidade do solo.

$\mathrm{O}$ uso do conceito do filocrono e do número de folhas vivas perfilho $^{-1}$ no capim Tanzânia 1 , pode constituir-se numa técnica promissora para determinar o manejo de pastagens de Tanzânia 1, muito embora outros trabalhos sejam necessários para validar ou adequar os valores encontrados. É provável que a definição da freqüência de pastejo para o capim Tanzânia 1 seja determinada em função do valor nutricional e/ou taxa de utilização da forragem disponível uma vez que o início da senescência de folhas não reduz a taxa de acúmulo líquido de matéria seca na planta.

A densidade populacional de perfilhos se manteve relativamente constante durante o período experimental, porém, houve uma variabilidade nas categorias de perfilhos que constituem o pasto, devido a queda nas taxas de aparecimento no período da "seca". Em função deste fato, sugere-se determinar qual a categoria de perfilhos responsável pela maior parte da produção e basear o manejo no comportamento desta. O comportamento do perfilhamento do capim Tanzânia 1 caracterizado por emitir perfilhos durante todo o ano indica ser planta promissora para exploração intensiva através de pastejo intensivo.

O sistema de pastejo intensivo do capim Tanzânia 1 apresentou viabilidade econômica, com um lucro estimado de US\$530,04 $\mathrm{ha}^{-1}$ ano $^{-1}$. 


\section{REFERÊNCIAS BIBLIOGRÁFICAS}

ADJEI, M.B.; MISLEVY, P.; KALMBACHER, R.S.; BUSEY, P. Production, quality and persistence of tropical grasses as influenced by grazing frequency. Soil and Crop Science Society of Florida, v.48, p.1-6, 1989.

ANDRADE,J.B. Estudo comparativo de três capins da espécie Panicum maximum, Jacq (colonião, Tabiatã e K-87B). Piracicaba, 1987. 131p. Dissertação (Mestrado) - Escola Superior de Agricultua "Luiz de Queiroz“, Universidade de São Paulo.

ANSLOW, R.C. The rate of appearecence of leaves on tillers of the gramineae. Herbage Abstracts, v.36, n.3, p.149-155, 1996.

ASSOCIATION OF OFFICIAL ANALYTICAL CHEMISTS. Official methods of analysis. 16. ed., Washington. 1995. 1015p. $2 \mathrm{v}$.

BALSALOBRE, M.A.A. Desempenho de vacas em lactação sob pastejo rotacionado de capim elefante (Pennisetum purpureum Schum.) Piracicaba, 1996. 139p. Dissertação (Mestrado) - Escola Superior de Agricultura "Luiz de Queiroz", Universidade de São Paulo.

BARBOSA, M.A.A.F.; CECATO, U.; ONORATO, M.W.; COELHO, E.M. Estudo do perfilhamento do capim Mombaça (Panicum maximum Jacq.). In: REUNIÃO DA SOCIEDADE BRASILEIRA DE ZOOTECNIA, 34., Juiz de Fora, 1997. Anais. Juiz de Fora: SBZ, 1997. p.114-116. 
BARBOSA, M.A.A.F.; DAMASCENO, J.C.; CECATO, U.; SAKAGUTI, E.S. Influência da eliminação do meristema apical no aparecimento de perfilhos, em quatro cultivares de Panicum maximum Jacq. In: REUNIÃO DA SOCIEDADE BRASILEIRA DE ZOOTECNIA, 33., Fortaleza, 1996. Anais. Fortaleza: SBZ, 1996. p. 104-105.

BARBOSA, R.A; EUCLIDES, V.P.B. Valores nutritivos de três ecótipos de Panicum maximum Jacq. In: REUNIÃO ANUAL DA SOCIEDADE BRASILEIRA DE ZOOTECNIA, 34., Juiz de Fora, 1997. Anais. Juiz de Fora: SBZ, 1997. p.53-55.

BIRCHAN, J.S.E.; HOGDSON, J. The influence of sward on rates of herbage growth and senescence under continuos stacking management. Grass and Forage Science, v.38, p.323-331, 1983.

BOONMAN, J.G. Experimental studies on seed production of tropical grasses in Kenya.5. The effect of time of nitrogen top dressing on seed crops of Setária sphacelata cv. Nandi. Netherlands of Journal of agricultural Science, v.20, p.225231,1971 .

BROUGHAM, R.W. Pasture growth rate studies in relation to grazing manegement. Procedings of the New Zealand Society of Animal Production, v.17, p 46-55, 1957. 
CARNEVAlli, R.A.; SILVA, S.C. Avaliação de características agronômicas e ecológicas de Cynodon dactylon para validação de técnicas para ensaios de pastejo. In: REUNIÃO ANUAL DA SOCIEDADE BRASILEIRA DE ZOOTECNIA, 35, Botucatu, 1998. Anais. Botucatu: SBZ, 1998. p.418-420.

CARO COSTAS, R.; VICENTE CHANDLER, J. Effects of two cutting heights on yields of live tropical grasses. Journal of Agricultural of the University of Puerto Rico, v.45, n.1, p.46$49,1961$.

CARRIEL, J.M.; PEDREIRA, J.V.S.; MATTOS, H.B. Estimativa da ocorrência dos principais capins no estado de São Paulo. Zootecnia, v.17, n.1, p.5-25, 1979.

CECATO, U.; MARCO, A.A.F.B.; SAKAGUTI, E.S.; DAMASCENO, J.C.; SUZUKI, E.; MEURER, F. Avaliação de cultivares de Panicum maximum Jacq. In: REUNIÃO ANUAL DA SOCIEDADE BRASILEIRA DE ZOOTECNIA, 34., Fortaleza, 1996. Anais. Fortaleza: SBZ, 1996. P.403-406.

COLLINS, R.P.; JONES, M.B. The effects of temperature on leaf growth in Cyperus longus, a temperate C4 species. Annals of Botany, v.61, n.3, p.335-362, 1988.

COMBELLAS, J.; HOGDSON, L. Herbage intake and milk production by grazing dairy cows. Grass and Forage Science, v.34, p.303-310, 1979. 
CORREA, L.A. Níveis críticos de fósforo para o estabelecimento de Brachiaria decumbens Stapf.Brachiaria brizanta (Hochst.) Stapf. cv.Marandu e Panicum maximum Jacq. em Latossolo VermelhoAmarelo álico. Piracicaba, 1991. 83p. Tese (Doutorado)- Escola Superior de Agricultura "Luiz de Queiroz", Universidade de São Paulo.

CORRÊA, L.A. Produção intensiva de carne a pasto. In: CONVENÇÃO NACIONAL DA RAÇA CANCHIN, São Carlos, 1997. São Carlos: EMBRAPA, CPPSE, 1997. p.99-105.

CORREAA, L.A.; FREITAS, A.R.; BATISTA, L.A.R. Níveis de nitrogênio e frequência de corte em 12 gramíneas forrageiras tropicais. I- Produção de matéria seca. In: REUNIÃO ANUAL DA SOCIEDADE BRASILEIRA DE ZOOTECNIA, 35, Botucatu, 1998a. Anais. Botucatu: SBZ, 1998a. p.304-306.

CORREAA, L.A.; FREITAS, A.R.; BATISTA, L.A.R. Níveis de nitrogênio e frequência de corte em 12 gramíneas forrageiras tropicais. II- Qualidade de forragem. In: REUNIÃO ANUAL DA SOCIEDADE BRASILEIRA DE ZOOTECNIA, 35, Botucatu, 1998b. Anais. Botucatu: SBZ, 1998b. p.518-520.

CORSI, M. Effects of nitrogen retes and harvesting intervals on dry matter production, tillering and quality of the tropical grass Panicum maximum, Jcaq. Ames, 1984a. 125p. Thesis (Ph.D.)Ohio State University. 
CORSI, M. Uréia como fertilizante na produção de forragem. In: SIMPÓSIO SOBRE NUTRIÇÃO DE BOVINOS, 2., Piracicaba, 1984. Anais. Piracicaba: FEALQ, 1984b. p.275-285.

CORSI, M. Manejo das plantas forrageiras do gênero Panicum. In: SIMPÓSIO SOBRE MANEJO DA PASTAGEM, 9., Piracicaba, 1988. Anais. Piracicaba: FEALQ, 1988, p.57-75.

CORSI, M. Manejo do capim elefante sob pastejo. In: SIMPÓSIO SOBRE MANEJO DA PAStagem, 10., Piracicaba, 1993. Anais. Piracicaba: FEALQ, 1993.p.143-167.

CORSI, M.; NASCIMENTO JUNIOR, D. do. Princípios de fisiologia e morfologia de plantas forrageiras no manejo das pastagens. In: PEIXOTO, A.M.; MOURA, J.C.; FARIA, V.P. de. (Ed.) Piracicaba, 1994. Pastagens: fundamentos da exploração racional. 2. ed. Piracicaba: FEALQ, 1994. p. 15-47.

CORSI, M.; NUSSIO, L.G. Manejo do capim elefante: correção e adubação do solo. In: SIMPÓSIO SOBRE MANEJO DA PASTAGEM, 10.,Piracicaba, 1993. Anais. Piracicaba: FEALQ, 1993. p.87-116.

CORSI, M.; SANTOS, P.M. Potencial de produção do Panicum maximum. In: SIMPÓSIO SOBRE MANEJO DA PASTAGEM, 12., Piracicaba, 1995. Anais. Piracicaba: FEALQ, 1995. p.275-304.

CORSI, M.; BALSALOBRE M.A.; SANTOS P.M.; SILVA, S.C. Bases para o estabelecimento do manejo de pastagem de brachiaria. In: SIMPÓSIO SOBRE MANEJO DA PASTAGEM, 11., Piracicaba, 1994. Anais. Piracicaba: FEALQ, 1994. p.249266. 
COSTA , N.L.; OLIVEIRA, J.R.C. Produção de forragem e composição química de Panicum maximum cv. Tobiatã em diferentes idades de corte. In: REUNIÃO ANUAL DA SOCIEDADE BRASILEIRA DE ZOOTECNIA, 34., Juiz de Fora, 1997. Anais. Juiz de Fora: SBZ, 1997. p.222-224.

DAVIES, A. Changes in growth rate and morphology of perenial ryegrass swards at high and low nitrogen levels. Journal of Agricultural Science, v.77, n.1, p.123-134, 1971.

DAVIES, A. Tissue turnover in the sward. In. DAVIES, A.; BAKER, R.D.;GRANT, S.A.; LAIDLAW, A.S. (Ed.) Sward measurement handbook. Reading: The British Grassland Society, 1993. Cap.9, p. 183-216.

EUCLIDES, V.P.B. Valor alimentício de espécies forrageiras do gênero Panicum. In: SIMPÓSIO SOBRE MANEJO DA PASTAGEM, 12., Piracicaba, 1995. Anais. Piracicaba: FEALQ, 1995. p. 245-274.

EUCLIDES, V.P.B.; MACEDO, M.C.M.; VIEIRA,A.; OLIVEIRA, M.P. Evaluation of Brachiaria decumbens cultivars under grazing. In: INTERNATIONAL GRASSLAND CONGRESS, 17. Palmerston North, 1993. Palmerston North: New Zealand Grassland Association, 1993a. p.1997-1998.

EUCLIDES, V.P.B.; MACEDO, M.C.M.; VIEIRA,A.; OLIVEIRA, M.P. Evaluation of Panicum maximum cultivars under grazing. In: INTERNATIONAL GRASSLAND CONGRESS, 17., Palmerston North, 1993. Palmerston North: New Zealand Grassland Association, 1993b.p.1999-2000. 
FAVORETTO, V.; RODRIGUES, L.R.A.; TUPINAMBÁ, L.F. Estudo do nitrogênio na produção e composição bromatológica do capim colonião e seus aspectos econômicos. Cientifica, v. 16, n.1, p. $71-78,1988$.

FAVORETTO, V.; REIS, R.A.; VIEIRA, P.F.; MALHEIROS, E.B. Efeito da adubação nitrogenada ou de leguminosas no ganho de peso vivo de bovino em pastagens de capim colonião. Pesquisa Agropecuaria Brasileira, v.20, n.4, p.475-482, 1985.

FURLAN, R.S. Influência da frequência de intensidade de corte no capim colonião, (Panicum maximum, Jacq). Piracicaba, 1969. 105p. Tese (Doutorado). Escola Superior de Agricultura "Luiz de Queiroz". Universidade de São Paulo.

GOERING, H.K.; VAN SOEST, P.J. Forage fiber analyses: apparatus, reagents, procedures and some applications. Washington: USDA, 1970. 20p. (USDA. Agricultural Handbbok, 379)

GOMIDE, C.A.M. Morfogênese e análise de crescimento de quatro cultivares de Panicum maximum cultivadas em vaso. Viçosa, 1997. 53p. Dissertação (Mestrado) - Universidade Federal de Viçosa.

GOMIDE, C.A.M.; GOMIDE, J.A. Morfogenese e análise de crescimento de cultivares de Panicum maximum. In: REUNIÃO BRASILEIRA DE ZOOTECNIA, 33., Fortaleza, 1996. Anais. Fortaleza: SBZ, 1996. p. 403-405. 
GOMIDE, C.A.M.; GOMIDE, J.A.; QUEIROZ, D.S.; PACIULLO, D.S.C. Fluxo de tecidos em Brachiaria decumbens. In: REUNIÃO ANUAL DA SOCIEDADE BRASILEIRA DE ZOOTECNIA, 34., Juiz de Fora, 1997. Anais. Juiz de Fora: SBZ, 1997. v.2, p.117119.

GOMIDE, J.A. Adubação fosfatada e potássica de plantas forrageiras. In: SIMPÓSIO SOBRE MANEJO DA PASTAGEM, 2., Piracicaba, 1975. Anais. Piracicaba: FEALQ, 1975. p.143155.

GOMIDE, J.A. Adubação das pastagens estabelecidas. In: SIMPÓSIO SOBRE MANEJO DA PASTAGEM, 7., Piracicaba, 1984. Anais. Piracicaba: FEALQ, 1984. p.33-60.

GOMIDE, J.A.; OBEID, J.A.; RODRIGUES, L.R.A. Fatores morfofisiológicos de rebrota do capim colonião (Panicum maximum Jacq), Revista da Sociedade Brasileira de Zootecnia, v.8, n.4, p.532-562, 1979.

GRANT, S.A.; KING, J. Grazing manegement and pasture production: The importance of sward morphological adaptations and canopy photosynthesis. Hill Farming Research Organization, Biennal Report, p.119-129, 1983.

GRANT, S.A.; BARTHRAM, G.T.; TORVELL, L. Components of regrowth in grazed of cut Lolium perenne swards. Grass and Forage Science, v.36, n.3, p.155-168, 1981. 
GUERRERO, J.N.; CONRAD, B.E.; HOLT, E.C.; WU, H. Prediction of animal performance on bermudagrass pasture from available forage. Agronomy Journal, v.76, n. 1, p.577-580, 1984.

HAY, R.K.M.; WALKER, A.J. Introduction to the physiology of crop yield. London: Longman Scientific \& Technical, 1989. $292 \mathrm{p}$.

HERLING, V.R.; JANTALIA, C.P.; PIAZZA, C.; SUDA, C.H.; LUZ, P.H.C. de; LIMA, C.G. Determinação da matéria seca disponível do capim Mombaça (Panicum maximum Jacq. cv. Mombaça) sob pastejo. In: REUNIÃO ANUAL DA SOCIEDADE BRASILEIRA DE ZOOTECNIA, 35., Botucatu, 1998. Anais. Botucatu: SBZ, 1998a. p.530-532.

HERLING, V.R.; JANTALIA, C.P.; PIAZZA, C.; SUDA, C.H.; LUZ, P.H.C. de; LIMA, C.G. Fisiologia do perfilhamento do capim Mombaça (Panicum maximum Jacq. Cv. Mombaça) sob pastejo. In: REUNIÃO ANUAL DA SOCIEDADE BRASILEIRA DE ZOOTECNIA, 35., Botucatu, 1998. Anais. Botucatu: SBZ, 1998b. p. $533-535$.

HILL, G.M.; BORTON, G.W.; UTLEY, P.R.; GATES, R.N. Forage quality and steer performance on Tifton 78 and Coastal bermudagrass pasture. In: INTERNATIONAL GRASSLAND CONGRESS, 17., Palmerston North, 1993. Proceedings. Palmerston North: New Zealand Gassland Association, 1993. p.870-872. 
HILLESHEIM, A. Fatores que afetam o consumo e perdas de capimelefante (Pennisetum purpureum, Schum.) sob pastejo, Piracicaba, 1987. 84 p. Dissertação (Mestrado) - Escola Superior de Agricultura "Luiz de Queiroz", Universidade de São Paulo.

HODGSON, J.G. Grazing management: science into practice. Essex: Longman Scientific \& Technical, 1990. 203 p.

HORST, G.L.; NELSON, C.J.; ASAY, K.H. Relationship of leaf elongation to forage yield of tall fescue genotipes. Crop Science, v. 18, n.5, p. 715-719, 1978.

ILJIN, W. S. Relation entre suelo y composicion quimica de las plantas forrajeras. Agronomia Tropical, v.4, n.4,p.193-213, 1958.

JANK, L. Melhoramento e seleção de variedades de Panicum maximum. In: SIMPÓSIO SOBRE MANEJO DA PASTAGEM, 12., Piracicaba, 1995. Anais. Piracicaba: FEALQ, 1995. p.22-58.

JANK, I.; BATISTOTI, C.; FERREIRA, G.de F.C.R. Herança da característica estolonífera em Panicum maximum. In: REUNIÃO ANUAL DA SOCIEDADE BRASILEIRA DE ZOOTECNIA, 31., Maringa, 1994. Anais. Maringa: SBZ, 1994. p.304-307.

KORTE, C.J.; HARRIS, W. Effects of grazing and cutting. In: SNAYDON, R.W. Ecosystems of the world: managed grassland analytical studies. Amsterdam: Elsevier Science, 1987. p.71-79. 
KORTE, C.J.; SHEATH, G.W. Herbage dry matter production. The balance between growth and death. Proceedings of the New Zealand Grassland Association, n.40, p.152-161, 1979.

LEMAIRE, G.; CHAPMAN, D. Tissue flows in grazed plant communities. In: HOGDSON, J.; ILLIUS, A.W. (Ed.) The ecology and management of grazing systems. Wallingford: CAB International, 1996. cap.1, p.3-36.

L'HUILLIER, P.J. Effect of dairy cattle stocking rate and degree of defolation on herbage accumulation and quality in ryegrass White clover pasture. New Zealand Journal of Agricultural Research, v.30, p.149-157, 1987.

LOCH, D.S. Selecion of environmental and cropping system for tropical grasses. INTERNATIONAL GRASSLAND CONGRESS, 15., Palmerston North, 1980. Proceedings. Palmerston North: New Zealand Gassland Association, 1980.

MACHADO, A.O.; CECATO, U.; MIRA, R.T.; PEREIRA, L.A.F.; MARTINS, E.N.; DAMASCENO, J.C.; SANTOS, G.T. Avaliação de genótipos de Panicum maximum (Jacq.) em duas alturas de corte. In: REUNIÃO ANUAL DA SOCIEDADE BRASILEIRA DE ZOOTECNIA, 34., Juiz de Fora, 1997. Anais. Juiz de Fora: SBZ, 1997. p.219-221.

MARASCHIN, G.E. Sistema de Pastejo I. In: SIMPÓSIO SOBRE MANEJO DA PASTAGEM, 12., Piracicaba, 1986. Anais. Piracicaba: FEALQ, 1986. p.337-376. 
MARTINEZ, H.E.P. Níveis críticos de fósforo em Brachiaria decumbens (Stapf) Prains, Brachiaria hunidicula (Rendle) Schweickerdt, Digitária decumbens, Stent, hynutiflora Pal de Beauvy, Panicum maximum Jacq. e Pennisetum purpureum Schum. Piracicaba, 1980. 97p. Dissertação (Mestrado) Escola Superior de Agricultura "Luiz de Queiroz", Universidade de São Paulo.

MATTOS, H.B.; WERNER, J.C. Efeito do nitrogênio mineral e de leguminosas sobre a produção de capim Colonião (Panicum maximum, Jacq.). Boletim de Indústria Animal, v.36, n.1, p.147$156,1979$.

MINSON, D.J. The digestibility and voluntary intake of 6 varieties of panicum. Australian Journal of Experimental Agriculture and Animal Husbandry, v. 11, p. 18-25, 1971.

MINSON, D.J. Composicion quimica y valor nutritivo de las gramineas tropicales. In: SKERMAN, P.J.; RIVEROS, F. Gramineas tropicales. Roma: FAO, 1992. p.181-199 (Coleccion FAO. Produccion Vegetal, 23).

MISLEVY, P.; RUELKE, O.C.; MARTIN, F.G. Grazing evaluation of Cynodon species. Proceedings of Soil and Crop Science Society of Florida, v.47, p.207-212, 1988.

MONTEIRO, F.A. Adubação para estabelecimento e manutenção de capim elefante. In: CARVALHO, M.M.; ALVIN, M.J.; XAVIER, D.F.; CARVALHO, L.A. Capim-elefante: produção e utilização. Coronel Pacheco: CNPGL, 1990. p.35-37. 
MONTEIRO, F.A.; WERNER, J.C. Efeitos da adubação nitrogenada e fosfatada em capim colonião, na formação e em pasto estabelecido. Boletim da Indústria Animal, v.34, n.1, p.91-101, 1977.

MONTEIRO, F.A.; WERNER, J.C. Reciclagem de nutrientes em pastagem. In: SIMPÓSIO BRASILEIRO DE FORRAGEIRAS, Campinas, 1994. Anais. Campinas: Colégio Brasileiro de Nutrição Animal, 1994. p.41-65.

OLIVEIRA, M.A. Estudo do crescimento e valor nutritivo do capim Bachiaria (Brachiaria decumbens, Stapf), Piracicaba, 1980. 68p. Dissertação (Mestrado) - Escola Superior de Agricultura "Luiz de Queiroz", Universidade de São Paulo.

PARSONS, A.J.; PENNING, P.D. The effect of the duration of regrowth on photosyntesis, leaf death and the avarege rata of growth in a rotacionaly grazed sward. Grass and Forage Science, v.43, p. 15-27, 1988.

PEARSE, P.J.; WILMAN, D. Effects of applied nitrogen on grass leaf initiation devolopment and death in field swards. The Journal of Agricultural Science, v. 103, n.2, p.405-4 13, 1984.

PEDREIRA, C.G.S. Plant and animal responses on grazed pastures of Florakirk and Tifton 85 bermudagresses. Florida, 1995. 152p. Thesis (Ph.D.) - University of Florida. 
PEDREIRA, J.V.S. Crescimento estacional dos capins colonião (Panicum maximum, Jcaq), gordura (Melinis minutiflora, Paul de Beauav), jaraguá (Hyparrrhenia rufa (Ness.) Stapf.) e pangola de taiwan.a-24 (Digitaria pentzii Stent). Piracicaba, 1972. 117p. Tese (Doutorado). Escola Superior de Agricultura "Luiz de Queiroz", Universidade de São Paulo.

PEDREIRA, J.V.S. Crescimento estacional dos capins colonião (Panicum maximum,Jcaq), gordura (Melinis minutiflora, Paul de Beauav), jaraguá (Hyparrrhenia rufa (Ness.) Stapf.) e pangola de taiwan.a-24 (Digitaria pentzii Stent). Boletim da Indústria Animal, v.30, n.1, p.59-145, 1973.

PEDREIRA, J.V.S. Hábitos de perfilhamento do capim colonião (Panicum maximum, Jcaq). Boletim da Indústria Animal, v.32, n.1, p.111-114, 1975.

PEDREIRA , J.V.S.; SILVEIRA, J.N.N. Variação da composição bromatológica de capim colonião (Panicum maximum Jcaq). Boletim da Indústria Animal, v.29, n.1, p.185-190, 1972.

PEDREIRA, J.V.S.; MATTOS, H.B. Crescimento estacional de vinte e cinco espécies ou variedades de capins. Boletim da Indústria Animal, v.38, n.2, p. 117-143, 1981.

PINTO, J.C. Crescimento e desenvolvimento de ndropogon gayanus, Panicum maximum e Setaria anceps cultivadas em vasos, sob diferentes doses de nitrogênio. Viçosa, 1993. 149p. Tese (Doutorado) - Universidade Federal de Viçosa. 
PINTO , J.C.; GOMIDE, J.A.; MAESTRI, M.; LOPES, N.F. Crescimento de folhas de gramíneas forrageiras tropicais, cultivadas em vasos, com duas doses de nitrogênio. Revista da Sociedade Brasileira de Zootecnia, v.23, n.3, p.327-333, 1994.

PITMAN, W.D.; HODGES, E.M.; PEACOCK, F.M. Grazing evaluation of perennial grasses with yearling steers in peninsular Florida. Journal Animal Science, v.58,n.3, p.535-540, 1984.

POSTIGLIONI, S.R. Avaliação sob pastejo de gramíneas de estação quente na região dos campos gerais do Paraná. In: REUNIÃO ANUAL DA SOCIEDADE BRASILEIRA DE ZOOTECNIA, 34., Juiz de Fora, 1997. Anais. Juiz de Fora: SBZ, 1997. p.234-236.

QUINN, L.R.; MOTT, G.O.; BISSCHOFF, W.V.A. Fertilização de pastos de capim colonião e produção de carne com novilhos zebu. New York: IBEC, Research Institute, 1961. 40p. (Bulletin, 24).

ROBSON, M.J. Potencial production - What it is and can we increase it? In: WRIGHT C. E.(Ed.) Plant physiology and herbage production. British Grassland Society, 1981. p. 5-17.

ROCHA, G.P. Efeito da idade na composição química, digestibilidade "in vitro" e taxa de fermentação de oito gramíneas tropicais. Lavras, 1979. 104p Dissertação (Mestrado) - Escola Superior de Agricultura de Lavras. 
RODRIGUES, L.R.A.; REIS, A.R. Bases para estabelecimento do manejo de capim do gênero Panicum. In:. SIMPÓSIO SOBRE MANEJO DA PASTAGEM, 12., Piracicaba, 1995. Anais. Piracicaba: FEALQ, 1995. p.197-218.

RUGGIERI, A.C.; RODRIGUES, L.R.A.; PACOLA, L.J.; FIGUEIREDO, L.A.de; RAZZOK, A.G.; MALHEIROS, E.B. Avaliação dos capins Colonião, Tanzânia 1 e Marandu sob pastejo durante o período de estação de monta. In: REUNIÃO ANUAL DA SOCIEDADE BRASILEIRA DE ZOOTECNIA, 34., Juiz de Fora, 1997. Anais. Juiz de Fora: SBZ, 1997, p.237-239.

SAlisBURY, F.B.; ROSS, C.W. Plant physiology. 4.ed. Belmont, California: Wadsworth Publishing, 1992. 682p.

SANTOS, P.M. Estudo de algumas características agronômicas de Panicum maximum (Jacq.) cvs. Tanzânia 1 e Mombaça para estabelecer seu manejo. Piracicaba, 1997. 62p. Tese (Mestrado) Escola Superior de Agricultura "Luiz de Queiroz" - Universidade de São Paulo.

SÃo PAULO. Secretaria da Agricultura e Abastecimento. LUPA (Levantamento Censitário de Unidades de Produção Agrícola). São Paulo, 1997. 4V.

SARMENTO, C.M.B.; VEIGA, J.B.; COSTA, N.A.; NETO, N.S., ALVES, L.N. Avaliação de um sistema de manejo intensivo em pastagem de Tobiatã (Panicum maximum, BRA 001503). In: REUNIÃO ANUAL DA SOCIEDADE BRASILEIRA DE ZOOTECNIA, 34., Juiz de Fora, 1997. Anais. Juiz de Fora: SBZ, 1997. p.267-270. 
SAVIDAN, Y.H.; JANK, L.; COSTA, J.C.G. Registro de 25 acessos selecionados de Panicum maximum. Campo Grande: EmbrapaCNPGC, 1990. 68p. (Embrapa. CNPGC. Documentos, 44).

SETELICH, E.A.; ALMEIDA, E.X.da; MARASCHIN, G.E. Adubação nitrogenada e variáveis morfogênicas em capim elefante anão cv. Mott, sob pastejo. In: REUNIÃO ANUAL DA SOCIEDADE BRASILEIRA DE ZOOTECNIA, 35., Botucatu, 1998. Anais. Botucatu: SBZ, 1998a. p.152-154.

SETELICH, E.A.; ALMEIDA, E.X.da; MARASCHIN, G.E. Resposta a adubação nitrogenada de capim elefante anão cv. Mott, sob pastejo. In: REUNIÃO ANUAL DA SOCIEDADE BRASILEIRA DE ZOOTECNIA, 35., Botucatu, 1998. Anais. Botucatu: SBZ, 1998b. p. 155-157.

SINGH, R.D.; CHATTERJEE, B.N. Growth analysis of perenial grasses tropical india. Experimental Agriculture, v.4, n.2, p.117-125, 1968.

TEIXEIRA, E.I. Avaliação de características morfofisiológicas e nutricionais do capim Tobiatã (panicum maximum cv. Tobiatã) sob sistema de pastejo rotacionado. Piracicaba, 1998. 87p. Dissertação (Mestrado) - Escola Superior de Agricultura "Luiz de Queiroz", Universidade de São Paulo.

TILLEY, J.M.A.; TERREY, R.A. A two stage techinique for the in vitro digestion of forage crops. Journal of the British Grassland Society, v. 18, p 104-112, 1963. 
ThOMAS, H.; STOdDaRT, J.L. Leaf senescence. Annual Review of Plant Physiology, v.31, p.83-111, 1980.

USBERTTI FILHO, J.A. IAC-Centauro; novo cultivar de capim colonião de porte baixo e ciclo precoce. In: CONGRESSO PAULISTA DE AGRONOMIA, 6., Piracicaba, 1987. Anais. Piracicaba: FEALQ, 1987. p.149-164.

VEIGA, J.B.da. Utilização do capim-elefante sob pastejo. In: CARVALHO, M.M.; ALVIN, M.J.; XAVIER, D.F.; CARVALHO, L.A. Capim-elefante: produção e utilização. Coronel Pacheco: EMBRAPA, CNPGL, 1994, p.165-193.

VICENTE-CHANDLER, J.; SILVA, S.; FIGARELLA, J. Effect of frequency of app;ication on response of gruneagrass to nitrogen fertilization. Journal of the Agricultural University Puerto Rico, v.46, n.4, p. 342-349, 1962.

VIEIRA, J.D. Produção de matéria seca, coeficiente de digestibilidade e concentração de nutrientes no capim colonião (Panicum maximum Jcaq) em função dos cortes aos 30, 45, 60 e 75 dias. Piracicaba, 1979. 71p. Dissertação (Mestrado) - Escola Superior de Agricultura "Luiz de Queiroz", Universidade de São Paulo.

VINE, D.A. Sward structure changes within a perennial ryegrass sward: leaf appearence and death. Grass and Forage Science, v. 38, p. $231-242,1983$.

WATKINS, J.M.;SEVEREN, M.L. Effect of freqyency and height of cutting on yiel, stand, and protein content of dome forrages in El Salvador. Agronomy Journal, v. 43, n.6, p. 291-296, 1951. 
WERNER, J.C. Calagem para plantas forageiras. In: In. SIMPÓSIO SOBRE MANEJO DA PASTAGEM, 8., Piracicaba, 1986. Anais. Piracicaba: FEALQ, 1995. p.191-198.

WIHELM, W.W.; McMASTER, G.S. Importance of filocrono in studing development and growth in grasses. Crop Science, v.35, n.1,p.1-3, 1995.

WILSON, J.R.; MINSON, D.J. Prospects for improving the digestibility and inteke of tropical grasses. Tropical Grassland, v. 14, p.253-259, 1980.

ZIMMER, A.H.; EUCLIDES, V.P.B.; MACEDO, M.C.M. Manejo de plantas forrageiras do gênero Brachiaria. In: SIMPÓSIO SOBRE MANEJO DA PASTAGEM, 9., Piracicaba, 1988. Anais. Piracicaba: FEALQ, 1988. p.141-184. 


\section{APENDICE 1}

Dinâmica do perfilhamento: exemplos de cálculos utilizando os dados originais 


\section{Dinâmica do perfilhamento}

Demonstração da metodologia utilizada para cálculo da mortalidade, aparecimento e sobrevivência de perfilhos através dos dados originais.

Tabela 15. Dados originais de dinâmica do perfilhamento (método da área)

\begin{tabular}{|c|c|c|c|c|c|c|c|c|c|c|c|c|c|c|c|c|c|c|c|c|c|c|c|c|}
\hline \multirow{3}{*}{$\begin{array}{c}\text { Data da } \\
\text { contagem }\end{array}$} & \multicolumn{24}{|c|}{$\mathrm{N}^{\circ}$ de perfilhos área ${ }^{-1}$} \\
\hline & \multicolumn{4}{|c|}{ P1 } & \multicolumn{3}{|l|}{ P2 } & \multicolumn{2}{|l|}{ P3 } & \multicolumn{3}{|c|}{$p_{4}$} & \multicolumn{3}{|c|}{ P5 } & \multicolumn{3}{|c|}{ P6 } & \multicolumn{3}{|c|}{ P7 } & \multicolumn{2}{|r|}{ P8 } & \multirow{2}{*}{ Média } \\
\hline & A1 & $A 2$ & $\mathrm{A3}$ & A1 & $A 2$ & A3 & A1 & $A 2$ & $A 3$ & A1 & $A 2$ & $\mathrm{A3}$ & A1 & $A 2$ & A3 & A1 & A2 & A3 & A1 & A2 & $A 3$ & A1 & A2 A3 & \\
\hline $02 / 01 / 97$ & 700 & 790 & 1010 & & & & & & & & & & & & & & & & & & & & & 2500 \\
\hline $10 / 02 / 97$ & 390 & 370 & 510 & 530 & 211 & 532 & & & & & & & & & & & & & & & & & & 2543 \\
\hline $23 / 03 / 97$ & 190 & 200 & 380 & 422 & 161 & 491 & 300 & 220 & 300 & & & & & & & & & & & & & & & 2664 \\
\hline $03 / 05 / 97$ & 130 & 160 & 350 & 345 & 133 & 422 & 260 & 170 & 270 & 271 & 87 & 203 & & & & & & & & & & & & 2801 \\
\hline $06 / 07 / 97$ & 50 & 80 & 260 & 261 & 102 & 395 & 222 & 140 & 260 & 255 & 84 & 174 & 231 & 152 & 392 & & & & & & & & & 3058 \\
\hline $28 / 09 / 97$ & 15 & 60 & 162 & 61 & 72 & 244 & 161 & 122 & 193 & 233 & 80 & 171 & 201 & 142 & 236 & 223 & 221 & 326 & & & & & & 2923 \\
\hline $22 / 11 / 97$ & 10 & 28 & 45 & 41 & 43 & 181 & 76 & 96 & 153 & 177 & 62 & 133 & 153 & 109 & 181 & 217 & 186 & 280 & 403 & 368 & 394 & & & 3336 \\
\hline $03 / 01 / 98$ & 5 & 6 & 21 & 32 & 30 & 92 & 83 & 44 & 125 & 162 & 55 & 89 & 142 & 66 & 115 & 213 & 153 & 245 & 218 & 202 & 195 & 562 & 342663 & 3860 \\
\hline
\end{tabular}

$\mathrm{P}=$ População de perfilhos da mesma idade identificados com anéis da mesma cor.

$\mathrm{A}=$ Amostras (cada amostra contém 3 sub amostras)

A porcentagem de aparecimento foi calculada pelo número de perfilhos novos dividido pelo número de perfilhos existentes na ultima contagem.

Ex. 1. $(530 / 700)+(211 / 790)+(532 / 1010)=(75.71+26.71+52.67) / 3=51.70 \%$

Ex. $2 .(300 /(390+530))+(220 /(211+270))+(300 /(532+510))=(32.61+37.86+28.79) / 3=33.09 \%$

A porcentagem de mortalidade foi calculada pelo número de perfilhos existentes na ultima contagem menos o número de perfilhos sobreviventes, dividido pelo número de perfilhos existentes na ultima contagem.

Ex. 1. $((700-390) / 700))+((790-370) / 790)+((1010-510) / 1010)=(44.29+53.17+49.50) / 3=48.99 \%$

Ex. 2 . $(390+530)-(190+422) /(390+530)=33.48 \%$

A porcentagem de sobrevivência foi obtida subtraindo a mortalidade de 100 .

Ex. $1.100-33.48=66.52 \%$ de sobrevivência. 